\title{
Late Quaternary geomorphology and sedimentary processes in the Zambezi turbidite system (Mozambique Channel)
}

\author{
Fierens Ruth ${ }^{1,{ }^{*}}$, Droz Laurence ${ }^{1}$, Toucanne Samuel ${ }^{2}$, Raisson François ${ }^{3}$, Jouet Gwenael ${ }^{2}$, \\ Babonneau Nathalie ${ }^{4}$, Miramontes Garcia Elda ${ }^{1}$, Landurain Steven ${ }^{2}$, Jorry Stephan ${ }^{2}$ \\ ${ }^{1}$ IUEM-UBO-CNRS, UMR6538, Laboratoire Géosciences Océan, 29280 Plouzané, France \\ ${ }^{2}$ IFREMER Centre Bretagne, Unité de Recherche Géosciences Marines, 29280 Plouzané, France \\ ${ }^{3}$ Total, Centre Scientifique et Technique Jean Féger, 64000 Pau, France \\ * Corresponding author : Ruth Fierens, email address : Ruth.Fierens@univ-brest.fr
}

\begin{abstract}
:
The morphology and present-day sediment distribution of the Zambezi turbidite system was investigated using new bathymetric and sub-bottom profiler data as part of the PAMELA research project. The Zambezi turbidite system is composed of two depositional systems: a channelized fan (the Zambezi Fan) and a semi-confined fan (in the Intermediate Basin). The Zambezi Fan includes the Zambezi Valley, which is deeply incised in the Mozambique Channel and is more than three times as large and deep as the great Tanzanian and North Atlantic Mid-Ocean channels. The erosion in the Zambezi Valley is evidenced by its V-shaped morphology and the existence of a U-shaped thalweg affected by several generations of incisions. Based on echo facies and cores from literature, sediments of the Zambezi Fan are dominantly coarse-grained and fine-grained overbank deposits are infrequent. The distal portion of the Zambezi Fan is a main depositional area where typical transparent wedged-shape seismic bodies are interpreted as terminal lobes. Seismic facies in the Intermediate Basin are thought to represent mostly fine-grained turbidites intercalated with infrequent coarse-grained sheet-like turbidites. Hydrodynamic circulation (from surface eddies to the deep circulation of NADW) appears to have a great impact on the Mozambique Channel sedimentation and is suggested (1) to be involved in the delivery of the Zambezi River sediments along the Mozambique margin, (2) to entrain the upper suspended load of turbidity currents, contributing to the absence of fine-grained sedimentation and (3) to contribute to the erosion of the valley flanks leading to the exceptionally great dimensions of the valley.
\end{abstract}




\section{Highlights}

- The Zambezi turbidite system comprises a channelized fan and a semi-confined fan. The Zambezi Valley has an atypical morphology compared to other turbidite systems. Erosional processes dominate in the valley. From echo facies, deposition appears mainly fine-grained in the semiconfined fan. Oceanic and turbidity currents control sediment distribution and erosion.

Keywords : Zambezi turbidite system, Late Quaternary, multibeam bathymetry, sub-bottom seismic profiles. 


\section{Introduction}

Since Kuenen and Migliorini (1950) published the concept of turbidite sedimentation, turbidite systems have been the subject of numerous studies around the world. Turbidite systems are the most important clastic accumulations in the deep sea and are major targets for hydrocarbon exploration (Weimer and Link, 1991; Normark et al., 1993; Stow and Mayall, 2000; Pettingill and Weimer, 2002). Several types of turbidite accumulations are known in the deep sea and are associated with a diverse variety of sedimentary processes. Typically, they comprise aggrading channelized fans with lateral levees that funnel sediments towards the distal portions of margins (e.g. the Amazon Fan, Damuth and Flood, 1985; the Congo Fan, Babonneau et al., 2002; the Bengal Fan, Curray et al., 2003; the Monterey Fan, Klaucke et al., 2004). Ponded turbidites infill salt-, mud- 
or fault-related mini-basins without associated channelized fans (e.g. Gulf of Mexico, Winker, 1996; Prather et al., 1998 and Madof et al., 2009; Fangliao Fan, Hsiung et al., 2018). Between these two end-members, some transient fans are known, which have a transitory upstream ponded depocenter that accumulates inputs until the topographic low is infilled leading to the supply of a farther downslope fan (e.g. Niger Delta, Adeogba et al., 2005; Villafranca Fan, Gamberi and Rovere, 2011; Tanzanian fan, Fournier, 2016; Kaoping Fan, Hsiung et al., 2018).

Whatever the type of turbidite accumulation, it is widely acknowledged that the development of turbidite systems is controlled by multiple forcing factors, such as tectonics, climate, sea-level (SL) changes, sediment flux, topographic compensation, turbidity currents dynamics, etc. Nonetheless, the respective role, and interaction of these factors, remains poorly understood (Winkler, 1993; Covault and Graham, 2010; Hinderer, 2012; Romans et al., 2016). Consequently, open questions persist concerning sedimentary distribution on continental margins and the delivery mechanisms to deep-water environments.

Since the advances in bathymetry, acoustic imagery and seismic data technologies in the midtwentieth century, several deep-sea projects investigated the turbidite systems of the African margins (e.g. Droz et al., 1996; Babonneau et al., 2002; Antobreh and Krastel, 2006; Ducassou et al., 2007; Bourget et al., 2008; Fournier, 2016; Picot et al., 2016). Nevertheless, deep-sea depositional systems on the eastern African margins remain poorly studied. Initial research on the Zambezi turbidite system was undertaken in the 1980's by Kolla et al. (1980a, b). The Zambezi turbidite system is considered one of the largest turbidite systems in the world and was fed mainly by inputs of the Zambezi River (Fig. 1A). With a catchment area of $1.4 \times 10^{6} \mathrm{~km}^{2}$ the Zambezi River is the fourth largest river after the Congo, the Nile and the Niger on the African continent with a sediment load of $48 \times 10^{6} \mathrm{t} / \mathrm{yr}$ (Milliman and Syvitski, 1992). Kolla et al. (1980a, b) proposed 3 main subdivisions in the Zambezi Fan: inner-, mid- and outer-fan based on micromorphology and acoustic character. Furthermore, Droz and Mougenot (1987) argued the different evolution stages of the Mozambique 
Fan that became active since the Oligocene. More recently, scientific interest has increased considerably for the Zambezi turbidite system and new results based on higher resolution data sets were presented. Specific attention was paid to the transport of sediments on the upper margin (Schulz et al., 2011) and their delivery to the abyssal plain (Wiles et al., 2017a), the morphological character of the Zambezi Valley (Wiles et al., 2017b) and the influence of bottom currents on the seafloor morphology (Breitzke et al., 2017).

Despite this recently increasing interest, knowledge remains limited for large parts of the Zambezi turbidite system. Wiles et al. (2017b) suggested that large dimensions of the Zambezi Valley result from periods of increased fluvial input associated with the Zambezi River catchment history (elevated paleo-lakes discharge episodes). In addition, Wiles et al. (2017a) proposed that sediments from the Mozambique shelf get delivered to three different deep water depositional domains (Angoche Basin, Zambezi Valley and offshore Zambezi delta, Fig. 1) via multiple incisions on the slope. Breitzke et al. (2017) described a large variety of morphological current-controlled bedforms and linked them to the flow paths of Antarctic Bottom Water (AABW, Fig. 2) and North Atlantic Deep Water (NADW, Fig. 2). However, these authors' hypotheses are all based on limited surface mapping, with focus on the continental slope (Wiles et al., 2017a) and the downstream portion of the Zambezi Valley (Breitzke et al., 2017; Wiles et al., 2017b).

This contribution provides the most complete geomorphological study of the Zambezi turbidite system. It is based on spatially extensive bathymetric and very high-resolution seismic data that allow for the first time to understand the recent morpho-sedimentary evolution of the entire Zambezi Valley from the upper portion to the terminal lobes. Accurate slope and size evolutions of the valley result from a continuous along-valley survey and numerous transects. This study strengthens the peculiarity of the Zambezi turbidite system among other large turbidite systems. Sub-bottom profiles bring high quality images of the subsurface sediments and more especially provide new insights into the upper portion of the turbidite system, highlighting the variety of 
sedimentary processes shaping the Zambezi turbidite system. The predominance of coarse-grained deposits in the whole system, from the upper canyon to the distal lobes, demonstrates enhanced reservoir potential from a hydrocarbon exploration point of view. Occurrence of bedforms, erosional features and over-sized V-shaped valley morphology as described in this study, are among the major diagnostic criteria for identification of the influence of bottom currents on the system. The findings of this paper allow to amend and refine sedimentary models of turbiditic systems controlled by along slope currents, useful for the interpretation of subsurface data, and thus provide significant impact for the hydrocarbon industry.

\section{Regional settings}

\subsection{Main features in the Mozambique Channel}

The Mozambique Channel (between Mozambique and Madagascar) and its southward extension, the Mozambique Basin, are located in the western part of the Indian Ocean (Fig. 1).

The Mozambique Channel was created in the Early Jurassic-Early Cretaceous when Africa and Antarctic separated during the breakup of the supercontinent Gondwana (Leinweber and Jokat, 2012; Mahanjane, 2014). The study area comprises several volcanic and structural features inherited from this geodynamic evolution. The Davie Ridge (Fig. 1B) is a prominent N-S trending bathymetrical high along which the Madagascar continent has drifted southwards (Pique, 1999). About $80 \mathrm{~km}$ off the Mozambican coast, the Beira High (Fig. 1B) forms a prominent basement high, which is interpreted to be a continental fragment (Mahanjane, 2012; Mueller et al., 2016). This crustal structure served as a morphological barrier for sediments originating from the Mozambique margin and is now buried. The Mozambique and Madagascar Ridges (Fig. 1B) are aseismic plateaus, located in the extension of the Mozambique and Madagascar margins, respectively. Their continental or oceanic nature is still under debate (Leinweber and Jokat, 2011; Zhang et al., 2011; Fischer et al., 
2016). In the central part of the Mozambique Channel, isolated carbonate platforms are present, known as the Iles Eparses (Bassas da India Atoll, Europa Island, Jaguar and Hall banks), which are developed on top of volcanic edifices (Courgeon et al., 2016; Jorry et al., 2016). Together with the Mozambican continental slope and the Zambezi Valley, they enclose a confined basin that is referred to as the Intermediate Basin in this paper (see section 4.1). This basin is also partly constrained by contourite ridges of considerable thickness $(>1200 \mathrm{~m}$ ) that are deposited from Oligocene to Early Miocene and during the Neogene (Fig. 1B, Raisson et al., 2016). These thick and extended deposits attest of the strength of oceanic currents and the contribution of contouritic sedimentation in the Mozambique Channel.

The Zambezi Valley is long and curvilinear and links the Mozambique margin to the deepest portions of the Mozambique Basin. The valley lacks a present-day direct connection to the Mozambique continental shelf. However, during the Last Glacial Maximum, the Mozambican shelf was incised by the Chinde-Zambezi paleo-valley (Beiersdorf et al., 1980) that funneled Zambezi inputs towards gullies and channels of the Mozambique continental slope (Wiles et al., 2017a). The supposed upstream prolongation of the valley to the shelf break is located $200 \mathrm{~km}$ northeastwards from the Zambezi River outlet. The Zambezi Valley is transverse to the Mozambique Margin in its upper portion, NW-SE along the Oligocene and Miocene contouritic ridges (Raisson et al., 2016) that control its course. The valley deflects towards the south when it approaches the Davie Ridge and passes through a Miocene fault zone, still active today (hatched in Fig. 1B) identified by Courgeon et al. (2017) and Deville et al. (2018) as a prolongation of the eastern branch of the East African Rift System. The valley flows thereon east of the Eparses carbonate platforms (Courgeon et al., 2016). At around $22^{\circ} \mathrm{S}$, the Zambezi Valley merges with the Tsiribihina Valley, which originates from the Madagascar margin. The submarine valley ends in the Mozambique Basin (Fig. 1B) in the form of a distal coarse-grained depositional area (Kolla et al., 1980b). Between $21^{\circ} \mathrm{S}$ and $25^{\circ} \mathrm{S}$, the valley flows on an area that underwent a structural doming during the Late Miocene that affected the Cretaceous 
to Pliocene sediments and resulted in the confinement of turbidites upstream the structural dome (Ponte, 2018).

Previous studies have already defined some subsurface sedimentary features in the Mozambique Channel (Fig. 1B). Wiles et al. (2017a) stated that the base of the Beira High terrace is delineated by a moat and a separated sediment drift. Downstream from the Zambezi Valley, the distal coarsegrained deep-sea depositional area (Kolla et al., 1980a, b) is flanked on its western side by large-scale seafloor bedforms (Breitzke et al., 2017). These bedforms are called sediment waves, a generic term provided by Wynn et al. (2000) describing large-scale deep-water depositional bedforms that may be generated beneath along slope-flowing bottom currents or downslope-flowing turbidity currents. Finally, in addition to the Oligocene-Miocene contourite ridges (Raisson et al., 2016), several contourite drifts have been identified on top of the Mozambique Ridge (Raillard, 1990; Thompson, 2017). Sedimentary core data was previously retrieved from the study area (Fig. 1B) and indicated mainly a terrigenous origin of the Quaternary sediments (Simpson et al., 1974; Kolla et al., 1980a; Hall et al., 2016).

\subsection{Hydrodynamic settings}

The Mozambique Channel is a very dynamic area characterized by large surface gyres and intense deep circulation (Fig. 2). The modern surface circulation in the Mozambique Channel is dominated by a train of deep-reaching anticyclonic eddies with a large diameter (over $300 \mathrm{~km}$ ). These counter clockwise (anticyclonic) features propagate southward and generate a poleward flow of about $15 \mathrm{~Sv}$ (1 Sv $=10^{6} \mathrm{~m}^{3} / \mathrm{s}$ ) along the Mozambique margin, generally described in the literature as the Mozambique Current (De Ruijter et al., 2002). This Mozambique Current was established in the Early Miocene (Walford et al., 2005). Temporary clockwise (cyclonic) gyres occur southwest of Madagascar and can proceed in westerly or west-southwesterly direction towards the African continent (Quartly and Szokosz, 2004). 
Deeper circulation flows northward along the western margin of the Channel and is driven by the Mozambique Undercurrent (MUC) and Antarctic Bottom Water (AABW) (Fig. 2) (De Ruijter et al., 2002; Wiles et al., 2014). The MUC includes the Antarctic Intermediate Water (AAIW) between $800 \mathrm{~m}$ and $1500 \mathrm{~m}$ and the North Atlantic Deep Water (NADW) from $2000 \mathrm{~m}$ to $3500 \mathrm{~m}$ depth. The AAIW together with the upper portion of the NADW pass northwards along the northern part of the Davie Ridge before flowing across it into the Somali Basin (De Ruijter et al., 2002; Donohue and Toole, 2003; Van Aken et al., 2004; Breitzke et al., 2017). The decreasing depth of the seafloor around $20^{\circ} \mathrm{S}$ causes a segregation of the lower portion of the NADW that is deflected southward along the Madagascar margin (Van Aken et al., 2004). Depths below $4000 \mathrm{~m}$ are characterized by the northward flowing Antarctic Bottom Water Current (AABW). Where the bathymetry becomes shallower (around $25^{\circ} \mathrm{S}$ ) the AABW deflects towards the east then south forming a weaker return current at the eastern side of the Mozambique Basin (De Ruijter et al., 2002; Donohue and Toole, 2003).

\section{Data and methods}

This study is based on a total of $32,750 \mathrm{~km}$ of multibeam bathymetric data and very high-resolution sub-bottom profiles (Fig. 3 ) that were collected simultaneously, at a speed varying from 8 to 10 knots, throughout four different surveys (Table 1) as part of the PAMELA (Passive Margin Exploration Laboratory) research project (Bourillet et al., 2013).

\subsection{Bathymetric data}

Multibeam data acquisition parameters are summarized in Table 1. Bathymetric data were processed using Ifremer's software CARAIBES ${ }^{\mathrm{TM}}$ and later gridded to obtain digital terrain models (DTM) (WGS84) with a resolution between $30 \mathrm{~m}$ and $75 \mathrm{~m}$ depending on depth range. In order to fill the gaps, the GEBCO global bathymetric grid (GEBCO, 2014) with a spatial resolution of 30 arc-seconds 
was added to the bathymetric data set. ArcGISTM v10.3.1 was used to display the bathymetric DTM's using World Mercator as map projection. Finally, the bathymetric data were superimposed on a slope raster (or vice-versa).

\subsection{Sub-bottom profiler data}

Very high-resolution seismic reflection profiles were collected using an IXSEA ECHOES 3500 subbottom profiler system operating in a chirp configuration $(1.8-5.3 \mathrm{kHz})$. Data were processed using Ifremer's QC Subop software and displayed by HIS Kingdom Suite software. Chirp data provide a penetration up to $100 \mathrm{~ms}$ twt $(75 \mathrm{~m})$, depending on seafloor roughness and sediment composition, with a vertical resolution of $0.3 \mathrm{~m}$. In order to provide an estimate for the subsurface sediments depths and thicknesses, the seismic velocity is approximated to $1500 \mathrm{~m} / \mathrm{s}$ to convert two-way times (s) to depth $(\mathrm{m})$ for both sea water and subsurface strata.

From sub-bottom data, superficial echo facies were derived, classified and compiled to produce an acoustic facies map by interpolation between the survey lines. The limits between the echo facies are not sharp, except locally, and generally correspond to progressive variations of amplitudes, frequencies or continuity of the sub-bottom reflections. In addition, the density of chirp sub-bottom data is generally low and interpolation is missing high-resolution changes. Taking these uncertainties into account, the produced echo facies map (see section 4.3) is necessarily an approximation of the distribution of the echo classes in the Mozambique Channel.

\subsection{Nomenclature of used morphological terms}

\subsubsection{Zambezi Fan and Zambezi turbidite system}

The turbidite systems are usually given the name of the rivers that feed the systems. Concerning the Zambezi River inputs, they are distributed all along the Mozambican margin (see section 4). A part of these inputs is used to construct the Zambezi Fan (or channelized fan), characterized by the Zambezi Valley with its tributaries (southern branch, Serpa Pinto, Tsiribihina), the distal distributaries and the 
depositional area. The other part is feeding the canyons and channels that funnel sediments towards the Intermediate Basin. Therefore, the Zambezi turbidite system is the combination of these two very different depositional systems.

\subsubsection{Zambezi Valley}

The Zambezi Valley shows a particular cross-sectional shape consisting of a V-shaped upper portion and a U-shaped lower portion, denominated the thalweg (Fig. 4A), separated by main slope changes (Fig. 4B). The U-shaped portion is limited laterally by highly sloping flanks ( 15\%), while the Vshaped portion is characterized by gentler sloping flanks ( $3 \%)$. Outside the valley, the valley borders (see Fig. 4A, B) are flat to very gently sloping ( $0.7 \%$ ) with possibly some bedforms.

\subsection{Measurements of morphological parameters}

\subsubsection{Morphometrics of the valley and thalweg}

In order to fully quantify the morphological specificities of the Zambezi Valley and be able to compare its dimensions with valleys of other well-known turbidite systems (see Section 5.1), measurements were performed on the U-shaped lower portion as well as the V-shaped upper portion, as shown in figure 4B. When the slope changes marking the valley and thalweg limits are not at the same depth on the right and left hand sides of the valley, thalweg relief (Rt) and valley relief (Rv) were measured at the mid-depth (see for example Rv in figure 4B).

The cross-sectional areas of the upper portion of the valley and the thalweg were approximated using a triangular shape and a rectangular form, respectively (Fig. 4C). The valley and thalweg crosssectional areas (respectively $\mathrm{Av}$ and $\mathrm{At}$ ) are calculated from the formula given in figure $4 \mathrm{C}$. The measurements were done similar to those described for previous studies, e.g. Congo Fan (Babonneau et al., 2002), Amazon Fan (Pirmez and Imran, 2003), Tanzanian Fan (Bourget et al., 2008 and Fournier, 2016) and North Atlantic Mid-Ocean Channel (NAMOC; Hesse et al., 1987). 


\subsubsection{Morphometrics of bedforms}

Between the Iles Eparses and the Zambezi Valley, from approximately $\mathrm{S} 20^{\circ}$ to $\mathrm{S} 25^{\circ}$, the sea floor is covered by large bedforms characterized by a succession of crests and troughs (see Section 4.3). In order to typify these bedforms we used morphological parameters (wavelength, WL; wave height, WH; crest length, LC) defined in figure 5.

\section{Results and interpretation}

\subsection{Regional scale morphological character}

The Mozambique Channel approximates a rectangular trough with a North-to-South direction and varies in width between $430 \mathrm{~km}$ at $17^{\circ} \mathrm{S}$ and $1300 \mathrm{~km}$ at $28^{\circ} \mathrm{S}$. It is characterized by a North to South bathymetric variability (Fig. 6): the bowl-shape encountered in the North (profile d, Fig. 6B) changes to a flat-bottomed shape to the South where the basin is bounded by the Mozambique and Madagascar Ridges (profile h, Fig. 6B). The Mozambique margin can be subdivided into 3 different morphological parts (depth transects a to c, Fig. 6C) based on main slope changes. The most upstream portion has a concave shape with a substantial decrease in slope percentage (from $2.1 \%$ to $0.11 \%$ in profile b, Fig. 6C). At approximately $950 \mathrm{~km}$ (profile a) and $750 \mathrm{~km}$ (profile c), seaward, a significant increase in slope gradient (from $0.11 \%$ to $0.6-0.7 \%$ ) is observed over a distance of 100 to $200 \mathrm{~km}$ at approximately $3500 \mathrm{~m}$ water depth. This slope increase limits the Mozambique Basin northwards and probably corresponds to the southward limit of the area that was uplifted during the Miocene (Ponte, 2018). At the most distal part of the basin, the seafloor becomes smoother and more regular with a lower slope gradient ( $0.16 \%$ to $0.03 \%$, profile a, Fig. $6 \mathrm{C})$.

\subsection{High-resolution upstream-downstream morphological evolution of the Zambezi Valley and Tsiribihina Valley}

\subsubsection{The Zambezi Valley}


The Zambezi Valley appears as a very long (> $1200 \mathrm{~km}$ from the shelf break), very wide V-shaped valley (up to $53 \mathrm{~km}$ wide at the apex of the "V") with an up to $15 \mathrm{~km}$ wide U-shaped thalweg (Figs. 7; see also Fig. 4). The V-shaped valley is up to $750 \mathrm{~m}$ deep and has a slightly sinuous course at the regional scale.

At a regional scale, the longitudinal depth profile along the Zambezi Valley and its down-fan prolongation (Figs. 7C, 8) shows that the valley floor is at grade. However, from $\mathrm{km} \sim 900$ to $\mathrm{km}$ 1600, a ca. $700 \mathrm{~km}$ long abnormal sea floor elevation is observed. This elevation begins $200 \mathrm{~km}$ upstream the present-day Zambezi Valley mouth. It is found more downstream than the Miocene structural dome identified by Ponte (2018) (Figs. 1B and 6C) and therefore probably do not refer to this tectonic morphology. It is rather interpreted as a sedimentary accumulation inside the valley. However, without information on the internal structure of this accumulation we cannot definitively prove this interpretation. If our hypothesis is correct, it could indicate that the valley mouth, previously located about $200 \mathrm{~km}$ upstream, prograded southwards since this elevation was created.

At higher resolution (Fig. 8), the slope of the valley floor generally decreases downstream (from 0.36 to $0.05 \%$ ), through successive slope changes. The slope increases at two principal areas, i.e. from 0.16 to $0.19 \%$ around the confluence with the Tsiribihina Valley ( $800 \mathrm{~km})$ and from 0.08 to $0.21 \%$ $(\sim 1350 \mathrm{~km})$. Down profile, the Zambezi Valley flares out and turns into an area with very low longitudinal slopes (0.05\%). Near the confluence with the Serpa Pinto paleo-valley (Fig. 8) and in the area where faults crosses the valley (Deville et al., 2018), an abrupt $80 \mathrm{~m}$ depth change attests the presence of a possible knickpoint. This slope variability suggests that the valley floor alternates areas of erosion and deposition and that the valley is currently not at equilibrium. Transverse profiles (Fig. 7B) show a significant widening of the U-shaped valley after the confluence with the Serpa Pinto Valley and Tsiribihina Valley.

The morphological variabilities of both the thalweg and valley are emphasized by the downstream evolution of width, relief, aspect ratio and cross-sectional areas (Fig. 9), based on nine measurements for the valley and 34 for the thalweg (Fig. 4D). Figure 9 clearly shows that the valley and the thalweg 
widths and reliefs evolve independently until the distance of about $1200 \mathrm{~km}$ (i.e. after cross-section 12 in Fig. 7B) where the upper V-shape of the valley disappears and only the thalweg remains (crosssection 13 in Fig. 7B). This area corresponds to the present-day mouth of the Zambezi Valley and the beginning of the wide erosional/depositional area of the distal Zambezi fan.

\section{Thalweg evolution}

The thalweg averages $7 \mathrm{~km}$ in width, although it varies between 4 and $15 \mathrm{~km}$ (Fig. 9B). The most important increases of width occurs at the confluence with Serpa Pinto Valley $+3 \mathrm{~km}$ with regards to the average value) and at about $1200 \mathrm{~km}$ where the thalweg widens rapidly (+ $8 \mathrm{~km}$ compared to the average). The most significant width decrease occurs at about $\mathrm{km} 770$, i.e. 15 kilometers upstream the confluence with the Tsiribihina Valley.

The average relief of the thalweg is $181 \mathrm{~m}$ (Fig. 9C) but shows a very high variability from $100 \mathrm{~m}$ to $290 \mathrm{~m}$. Two main relief increases are observed at 450 and $880 \mathrm{~km}$ associated with either the knickpoint of the fault zone or with the along-valley slope increase $(0.19 \%)$ at about $930 \mathrm{~km}$. A decrease of thalweg relief to $100 \mathrm{~m}$ is observed at the same position as the width decrease to $5 \mathrm{~km}$ ( $\mathrm{km} \mathrm{770,} \mathrm{Fig.} \mathrm{9B)} \mathrm{and} \mathrm{a} \mathrm{main} \mathrm{decrease} \mathrm{to} 56 \mathrm{~m}$ is observed at the end of the relief profile accompanying the widening of the distal portion of the Zambezi Valley.

Cross-sectional area of the thalweg is $1 \mathrm{~km}^{2}$ on average (Fig. 9E) and shows a similar variability to that of the relief curve (Fig. 9C). Numerous zones with increased area are observed, especially where the Serpa Pinto paleo-valley joins the Zambezi Valley $\left(2.3 \mathrm{~km}^{2}\right)$. The most important decrease to 0.5 $\mathrm{km}^{2}$ occurs around $\mathrm{km} 770$ correlative to low relief and width (Fig. 9B and C).

\section{Valley evolution}

Width and relief of the valley are significantly higher than the thalweg (up to $+45 \mathrm{~km}$ in width and $580 \mathrm{~m}$ in relief) and show a two-step increase until km 950 (Fig. 9C) and km 1050 (Fig. 9B), respectively. Further downstream the valley relief shows an abrupt decrease. The valley approaches the size of the thalweg at the beginning of the profiles until about $250 \mathrm{~km}$ and at the end of the 
profiles at about $1200 \mathrm{~km}$. The variability of these parameters is rather low, but possibly underestimated because of the small number of measurements $(n=9)$. The valley is characterized by average width of $30 \mathrm{~km}$ and relief of $470 \mathrm{~m}$. A significant increase of these parameters (from 10 to 30 $\mathrm{km}$ in width and from 150 to $600 \mathrm{~m}$ in relief) is observed around $400 \mathrm{~km}$ in the area of the Serpa Pinto confluence and fault zone. The parameters then increase more progressively up to $53 \mathrm{~km}$ in width and $758 \mathrm{~m}$ in relief after the Tsiribihina confluence.

The average valley cross-sectional area is $9 \mathrm{~km}^{2}$ (Fig. 9E) and shows a similar evolution to that of the width curve (Fig. 9B) with a maximum of $16 \mathrm{~km}^{2}$ between 850 and $1050 \mathrm{~km}$.

\subsubsection{The Tsiribihina Valley}

The lower course of the Tsiribihina Valley (Fig. 10), the main tributary originating from the Madagascan margin, shows different morphological characteristics compared to the Zambezi Valley: higher sinuosity, lower width ( 2 to $3 \mathrm{~km}$ ) and higher average slope $(0.28 \%)$. The longitudinal depth profile along the valley (Fig. 10A) is marked by 3 main knickpoints, indicating that the Tsiribihina Valley is not at an equilibrium state. The two most upstream knickpoints may be related to direction changes in meanders. The last one corresponds to the junction with the Zambezi Valley marked by a $17 \mathrm{~m}$ high scarp, indicating that the Tsiribihina Valley is a perched valley (Fig. 10A).

\subsection{Subsurface sediment distribution in the Mozambique Channel}

Four principal acoustic echo classes (stratified, transparent, opaque and hyperbolic, Table 2) have been recognized by examining the seafloor echo (sharp or prolonged) and the continuity, amplitude, frequency and geometry of sub-bottom echoes (see Section 3.2). These echo classes have been compiled into an acoustic facies map (Fig. 11A) that shows the extent of acoustic echo classes encountered at the ocean floor throughout the study area. Some examples of echo classes found in the subsurface are shown in table 2 and figures 11 to 13. 


\subsubsection{Acoustic facies and inferred sediments}

Stratified facies (class S) are characterized by continuous and parallel reflections that usually can be distinguished down to a depth of several tens of meters. This facies class suggests the presence of layered sedimentary deposits and can represent pelagic or hemipelagic sedimentation, turbidite deposits or contourites (Kolla et al., 1980b; Damuth and Olson, 2015; Miramontes et al., 2016). This echo facies class is subdivided into 4 different sub-classes (S1 to S4) based on clear differences in reflection frequency and amplitude.

-Sub-class S1 is defined by a continuous and sharp seafloor reflection along with several distinct, continuous, parallel sub-bottom reflections that show lateral variability in amplitude (Figs. 11A, 12, 13A). It is associated with areas of relatively smooth flat-lying to slightly undulated seafloor. This acoustic signature partly resembles to type $1 \mathrm{~A}$ facies proposed by Damuth and Olson (2015) and is interpreted as dominantly hemipelagic to pelagic sediments where infrequent interbeds of silt and/or sand can occur (Damuth, 1980, and references therein). It is mainly observed along the Mozambique and Madagascar upper margins (Fig. 11A). Considering that the continental slope domain of the Mozambique margin is cut by numerous valleys that extend southeastwards until the Iles Eparses (Fig. 1; Wiles et al., 2017a), the coarser interbeds could represent sheet-like turbidite deposits.

-Sub-class S2 is often found when the surface morphology is undulated. It comprises a distinct, continuous bottom echo with parallel, high-frequency and low amplitude sub-bottom reflections (Fig. 11A). This echo class, similar to echo type IB and 4 described by Damuth and Olson (2015), can represent hemipelagic to pelagic sedimentation or migrating sediment waves created by bottom currents.

-Sub-class S3 is observed on flat-lying seafloor and consists of a distinct, continuous seafloor echo together with numerous distinct, parallel, high-amplitude sub-bottom reflections (see Figs. 11A, 12C and 13D). It resembles to type IA defined by Damuth and Olson (2015) and can be interpreted as turbidite deposits. 
-Sub-class S4 is found at the right hand side of the most downstream portion of the Zambezi Valley and southern part of the study area where the seafloor is relatively flat. Besides an intermediate to distinct seafloor reflection, it is characterized by high frequency, parallel and continuous sub-bottom echoes with variable vertical amplitude (Figs. 11A, 13D). It differs from the S3 sub-class principally by lower frequency and amplitudes. This echo sub-class correspond to echo type 2 of Damuth and Olson (2015) indicating a moderate amount of interbedded silt and sand (Damuth, 1980, and references therein). The variation of amplitude in this sub-class may represent alternation in grain size in gravity deposits or alternation of hemipelagic deposits with coarse-grained sediments (Biscara, 2011).

The transparent facies (class T) (Figs. 11, 12) are characterized by the absence of reflections and are observed as lens-shaped depositional units. It corresponds to type 5 of Damuth and Olson (2015). This echo class is dominantly found in the southern part of the studied area in the Mozambique Basin at the end of the Zambezi Valley, where it shows a high-amplitude bottom reflection and transparent bodies limited by very high-amplitude sub-bottom reflections. This facies corresponds to coarsegrained sand as evidenced by cores VM14-79, VM14-80, VM19-219 and VM20-197 reported by Kolla et al. (1980a) (Fig. 11A) and is interpreted as stacked-up terminal lobes.

Locally, this echo facies class is also recognized on the Mozambique margin. When located on the upper slope, the transparent acoustic response is interpreted as slide deposits, while for the other areas turbidite sheets are considered (Wiles et al., 2017a).

The opaque echo facies (class 0 ) shows semi- to very-prolonged bottom echoes with no sub-bottom reflections (Fig. 11A, 13). It resembles to the echo type 3 defined by Damuth and Olson (2015). This facies is dominantly found along the Zambezi and Tsiribihina Valley floors where coarse to very coarse sediments have been recovered during Leg 25 DSDP drillings (site-243, Simpson et al., 1974) and cores VM19-212, VM20-195, VM20-193 and VM34-147 (Kolla et al., 1980a) (see Fig. 11A for locations of drillings and cores). Furthermore, difficulties to core the Zambezi Valley floor with 
traditional Kullenberg coring system and recovery of some gravel (PAMELA-MOZ2 survey, Robin and Droz, 2014) attest of the coarse-grained composition of sediments at the seafloor.

The hyperbolic facies (class H) (Figs. 11A, 13) is defined by large single or regular overlapping hyperbolic reflections with varying vortex depth characterized by strong surface echo (echo types 7 and 8 of Damuth and Olson, 2015). Sub-bottom reflections are generally absent, but discontinuous parallel reflections can be locally observed. These hyperbolae are generally artefacts due to steep slopes or microrelief of the seafloor or may represent very short wavelength sediment waves.

\subsubsection{Sediment distribution, morphology and tentative process-based interpretation}

Despite the approximations of the echo facies distribution (the variability of the echo classes is illustrated in Figs. 12 and 13) in relation to the size of the study area and the generally low density of the data (see Section 3.2), the studied area appears organized as three main sedimentary systems at regional scale (Fig. 11B): (i) the Zambezi Fan appears mainly coarse-grained and is dominated by its long valley with opaque facies (class 0 ) that ends up at a wide channelized and transparent zone (class T) characteristic of terminal lobes. Stratified facies (S3 and S4) interpreted as fine-grained turbidites (overflow of turbidity currents or channel-levee systems) are restricted to 6 zones of limited areal extent; (ii) close to the Mozambique and Madagascar margins, the sediments are mainly stratified (S1) and are supposed to relate to hemipelagic or contouritic sediments with episodic turbiditic contribution essentially from the Mozambique margin; (iii) to the west of the Zambezi Fan, the area is dominated by hyperbolic and stratified (S2) facies interpreted as contour current bedforms, as already observed by Kolla et al. (1980a) and in more detail by Breitzke et al. (2017).

\subsubsection{The Zambezi Fan}

Examining the high-resolution bathymetric data, the main morphological characteristic of the Zambezi Valley is that it suffered from erosion all along its course. Erosion resulted in a thalweg affected by several generations of incisions. These incisions are illustrated from North to South, in 
the upstream portion of the valley (Figs. 14 and 15), in the faulted zone (Fig. 16), in the confluence area with the Tsiribihina Valley (Fig. 17) and in the lowermost portion of the system (Fig. 18, 19).

Data acquired upstream the Zambezi Valley illustrate the morphology of the confluence area of two main tributaries, called the Northern and Southern branches, which converge to form the Zambezi Valley (Fig. 14). The confluence is located at $180 \mathrm{~km}$ off the Mozambique shelf break (see Fig. 4 for location of the $0 \mathrm{~km}$ reference point). The Northern branch is wider (4 to $6.5 \mathrm{~km}$ ) and deeper (180 m) than the Southern branch ( $4 \mathrm{~km}$ wide and $135 \mathrm{~m}$ deep). At the confluence the Northern branch valley floor lies $40 \mathrm{~m}$ deeper than the Southern branch valley floor (profile 4, Fig. 14) indicating that the Northern branch is currently the most active tributary of the Zambezi Valley. Downstream the confluence, the Zambezi Valley widens to $7.5 \mathrm{~km}$ (profile 5, Fig. 14).

The valley floor of the Northern branch hosts significant erosional features, contrarily to the valley floor of the Southern branch that is relatively smooth and regular in the area of the confluence. These erosional features are mainly ovoid asymmetrical forms that evoke amalgamated scour marks. The updip scarp of the most upstream scour observed is $50 \mathrm{~m}$ high (profile 1, Fig. 14), attesting to the strength of the erosional process that created these features. A long lasting erosion may also result in such high scarp. Successive incisions resulted in a double thalweg at the tributaries confluence (profile 4, Fig. 14). Large slide scars (e.g. $2.8 \times 2.9 \mathrm{~km}$ ) are observed mainly at the confluence and at the left flank of the Southern branch and attests of active instability processes. Smaller scars $(1 \mathrm{~km} \mathrm{x}$ $1 \mathrm{~km}$ ) on the left flank of the Northern branch evoke smaller slides associated to the proximity of the thalweg.

About 30 kilometers downstream in a wide meander curves, the thalweg exhibits polyphased incisions (e.g. Fig. 15). The asymmetrical cross-section of the thalweg (i.e., steep slope at the outer bend associated with incisions to gentle slope of the inner bend) suggests preferential deposition inside the meander and erosion at the outer bend. The along-thalweg depth profile (profile 1, Fig. 15) 
shows an irregularly decreasing slope, with a $20 \mathrm{~m}$ high scarp. At this location, the Zambezi thalweg has a width of about $5 \mathrm{~km}$ (profiles 2 and 3, Fig. 15).

Further downstream (Fig. 16), where the Zambezi Valley approaches the Davie Ridge and turns from North-West-South-East to North-South, the thalweg shows comparable polyphased incisions to those found more upstream (Fig. 15). However, scours are less numerous. Upstream, the thalweg is $7 \mathrm{~km}$ wide and shows two incisions separated by a medium high. The thalweg narrows locally to $5 \mathrm{~km}$ where the valley crosses the northward extension of the faulted area described by Deville et al. (2018) (Fig. 1). On the right hand side of the valley, normal faults with up to $100 \mathrm{~m}$ offset are observed on seismic profiles (Fig. 16C) and provoke the collapse of the western valley border. Faults A and B are still well expressed on the bathymetric map in the collapsed area. Inside the valley however, the faults are hardly recognized, possibly because of later erosion.

Inside the valley, the prolongations of the faults are barely observed, except that of fault A, which is expressed by small-scale topographic perturbations on the medium high between thalweg incisions. This is probably due to the fact that faults offsets have been erased by incisions, indicating that the observed thalweg incisions post-date the activity of these faults. As it is being supposed that the faults remained active (or were reactivated) very recently (Deville et al., 2018), we can infer that the thalweg incisions are currently active.

Incisions are still present at $780 \mathrm{~km}$ from the 0 reference point at the shelf break (see Fig. 4) where the Tsiribihina Valley joins the Zambezi Valley (Fig. 17A). The $17 \mathrm{~m}$ scarp separating both valleys (Fig. 10A) and the perched position of the Tsiribihina Valley emphasizes either that the Zambezi Valley was submitted to erosive flows after the occurrence of the confluence, or that the Tsiribihina Valley is fairly recent and has not yet acquired an equilibrium state.

As classically observed in meandering valleys (e.g. Dietrich et al., 1979; Dietrich and Smith, 1984) and in link with turbidity current behavior, the identified morphologic features and slopes of the Tsiribihina flanks are different on the outer and inner bends of the meanders (profiles 4 to 9, Figs. 10, 17B). Slide scars are predominant on the outer bends, indicating privileged erosion and instability 
processes and resulting in steep valley flanks. In contrast, the inner bends mainly show lineations parallel to the thalweg, have terraced or less steep flanks and are a privileged site of deposition. In the upstream portion of the Tsiribihina Valley, however, slide scars occur on both sides, and dominantly on the inner bend resulting in a steep inner valley flank (profiles 1 to 3 , Figs. 10, 17B). This indicates that, locally, instabilities may not be related to turbidity current behavior (or that current behavior is different).

The right hand-side of the Tsiribihina Valley, north of $21^{\circ} 40^{\prime} \mathrm{S}$, shows slightly arcuate bedforms (green lines in Fig. 17B) that are ca. $5 \mathrm{~m}$ high, and have an average wavelength of $750 \mathrm{~m}$. These bedforms are oriented NW-SE, i.e. oblique to the valley course and to lineations (blue lines in Fig. 17B) that are found on and parallel to the flanks of the Zambezi Valley. Owing to their orientations and sizes (Fig. 17B), we suggest that the bedforms on the right-hand side of the Tsiribihina Valley are sediment waves created by overflow of turbidity currents by analogy to other deep-sea fans (e.g. Migeon et al., 2000; Normark et al., 2002; Babonneau et al., 2012). Due to high slopes of the flanks, the Zambezi flanks lineations are imaged as hyperbolic echoes masking any strata on sub-bottom profiles. However, owing to their orientation parallel to the flanks, these lineations are suggested to be outcropping strata resulting from the erosion of the flanks. Such lineations are identified from $\mathrm{km}$ 550 to $\mathrm{km} 1100$.

4.3.2.2. The mouth of the Zambezi-Tsiribihina valley: the main depositional/erosional area of the fan

The distal portion of the turbidite system is mainly characterized by transparent echo facies (class T, Figs. 11A, 18), which are organized as superposed lens-shaped depositional units. They are interpreted as coarse-grained terminal lobes (see Section 4.3.1) extending along $700 \mathrm{~km}$ from the end of the opaque facies of the Zambezi Valley to the south and $420 \mathrm{~km}$ laterally. To the south and west of the transparent echo facies zone mainly hyperbolic echoes dominate; this delineates the 
southern and western extent of the terminal lobes (Fig. 11A). The position of this boundary is supported by sediments collected at DSDP Site 248 (Leg 25, Schlich et al., 1974), DSDP site 250 (Leg 26, Davies et al., 1974) and core VM29-79 (Kolla et al., 1980a), which register no more coarse sediments but only fine-grained clay deposits (for position of cores and drillings, see Fig. 11A).

A channel-levee system is identified to the west of the southern limit of the Zambezi Valley opaque facies. A seismic profile crossing the system obliquely (Fig. 18C) clearly shows sedimentary structures classically encountered in aggradational deep-sea fans (e.g. Amazon Fan, Flood et al., 1997), i.e. stratified, wedge-shaped levees and a higher amplitude channel fill. On the bathymetric map (Fig. 18B) this channel-levee system is parallel to and truncated by the Zambezi thalweg. It therefore appears to be an ancient feature related to the Zambezi Valley. The crests of the levees appear dismantled by E-W oriented incisions and the outer part of the western levee shows a scalloped shape. These E-W orientated features are conform to those observed by Breitzke et al. (2017) more westwards, and are believed to be due to erosion by bottom currents. Channel-levees linked to the Zambezi Valley are not observed elsewhere.

Intense erosion in the distal area, observed off the mouth of the Zambezi Valley, is manifest as northeast-southwest oriented, elongate, channel-like incisions (incisions A to C, Fig. 19). Analysis shows that incised distributary channels are numerous across the depositional area (Figs. 11B and $18 \mathrm{~A})$, mainly diverging radially from the end of the opaque facies of the Zambezi Valley, but some incisions are clearly not connected to the Zambezi distributaries.

In Fig. 19, at $240 \mathrm{~km}$ from the valley mouth, the most recent pathway (C3) is 1 to $1.5 \mathrm{~km}$ wide, shows an irregular axial depth profile bounded updip by a $45 \mathrm{~m}$ high scarp (profile 1, Fig. 19) and is up to 60 $m$ deep in cross-sections (profiles 2 and 3, Fig. 19). Erosional channel-like features, up to more than $100 \mathrm{~m}$ deep, are also observed (Fig. 18D) some tens of kilometers downstream from those of Fig. 19. These characteristics observed at more than $1450 \mathrm{~km}$ from the shelf break attest to powerful erosional processes affecting the distal portion of the system, at least until $4500 \mathrm{~m}$ water depth. 


\subsubsection{The Intermediate Basin: another sink for the Zambezi inputs}

The Mozambique margin is characterized by the draping S1 stratified facies, which can be interpreted mainly as hemipelagic or contouritic sediments (Fig. 11). This echo facies has the particularity to show lateral variations of reflections from low to very high amplitude. The high amplitude levels could relate to thin sheet-like coarse-grained turbidites that accumulate in the area southwest of the Zambezi Valley in the so-called Intermediate Basin (for location see Fig. 6). Wiles et al. (2017a) proposed a network of canyons and channels issuing from the Mozambique margin that could feed these turbidites.

Southeastwards, to the northeast of the lles Eparses, a zone with S3 stratified facies (Fig. 11A) with an infilling (i.e. onlapping) configuration, is interpreted as ponded tubidites that accumulated recently, locally between and on fossil sediment waves (see Fig. 20). This type of turbidite accumulation is also observed (but not mapped in Fig. 11) in numerous narrow elongated depressions between sediment waves (see Fig. 21). Taking into account that the Zambezi Valley is too deeply incised (more than $600 \mathrm{~m}$, Fig. 9) and moreover that this S3 zone is located very far from the valley (110 to $190 \mathrm{~km}$, depending on the relative location of the valley), we favor the hypothesis that these turbidites originate from the portion of the Mozambique margin facing the Zambezi delta (solid blue arrows in Fig. 11B).

The Mozambique margin is also characterized by several up to $20 \mathrm{~m}$ thick bodies of transparent facies (class T), interpreted as mass movement deposits (Fig.12A to E). These are infrequent on subbottom profiles in the studied area, but widespread instabilities are known at the shelf break (Cattaneo et al., 2017; Ponte, 2018).

\subsubsection{Bottom current controlled bedforms}

Adjacent to and west of the Zambezi Valley large zones of echo sub-class S2 are present (Fig. 11A). Cores from Kolla et al. (1980a) (VM19-214 and VM19-213, see Fig. 11A for location) revealed finegrained (foraminiferal ooze and clay) deposits that lead to interpret these wide S2 zones as fine- 
grained hemipelagic to pelagic sediments. The seafloor morphologies observed in these zones have been interpreted by Breitzke et al. (2017) as bedforms produced by bottom currents.

We provide here some additional examples that indicate the great variability of bottom current orientation that generating these bedforms. Four different sites are chosen to illustrate some of the sediment waves occurring in the Mozambique Channel (Figs. 20 to 23).

\section{Fossil sediment waves}

At about 3100 m water depth northeastward from the lles Eparses, NW-SE isolated sediment waves separated by a flat seafloor are present (Fig. 20). These straight, relatively symmetrical bedforms show an average wavelength (WL) of $2.1 \mathrm{~km}$, an average height (WH) of $78 \mathrm{~m}$ and their crests (LC) are on average $10.1 \mathrm{~km}$ long. The flat depressions in between these undulations are characterized by high-amplitude, continuous sub-bottom reflections with high frequency (echo facies S3, Table 2) suggesting the presence of turbidite sediments (Damuth and Olson, 2015). Chirp analysis shows that these turbidites drape the sediment waves, which therefore appear fossilized (Fig. 20). Turbidites are usually onlapping on reliefs, and do not drape topographic highs as observed here. However, a vertical exaggeration of the profile closer to 1:1 (Fig. 20D) shows that the morphology is nearly flat, i.e. easy to be overflowed by turbidity currents. These bedforms that are located inside a wide area where Breitzke et al. (2017) proposed the development of "arcuate bedforms" and could represent local straighter parts of a wider arcuate feature.

\section{Sub-circular bedforms}

Sediment waves characterized with dominant N-S and E-W orientations are identified at $100 \mathrm{~km}$ east of Bassas da India and $30 \mathrm{~km}$ west of the Zambezi Valley at a water depth of about $3000 \mathrm{~m}$ (Fig. 21). The whole of elements is part of a larger circular complex, wherein the central portion predominantly consists of $\mathrm{N}-\mathrm{S}$ features and the external portions are mainly composed of $\mathrm{E}-\mathrm{W}$ orientated elements. Examination of morphological relationships of both wave directions suggests 
that the E-W oriented features are a second generation. The N-S oriented sediment waves have an average wavelength (WL) of $3.2 \mathrm{~km}$ and average height (WH) of $59 \mathrm{~m}$. Their crests are slightly sinuous and can longitudinally be followed over an average length (LC) of $10.4 \mathrm{~km}$. The second generation (EW) features are smaller with an average wavelength (WL) of $2.1 \mathrm{~km}$, an average height (WH) of $33 \mathrm{~m}$ and an average crest length (LC) of $5.8 \mathrm{~km}$. On sub-bottom chirp seismic profiles (profiles 1 and 2, Fig. 21), these sediment waves show a distinct bottom echo with continuous internal reflections with high frequency and low amplitude (echo facies S2 in Table 2). This together with the draping and wavy configuration of reflections points to a hemipelagic nature of sediments reworked by bottom currents and therefore to contourites. This type of bedforms is referred to "irregular elongated and sub-circular depressions" by Breitzke et al. (2017).

\section{Polygonal sediment waves}

Seventy five kilometers southeast of Europa Island along the west flank of the Zambezi Valley (location in figure 11B), an area of sediment waves with no dominant orientation is observed (Fig. 22). The sediment waves extend over an area larger than $9000 \mathrm{~km}^{2}$ and can be described as rather symmetrical polygonal features developed upon a local high (Fig. 22, profile A). These symmetrically shaped morphologies are smaller than the previous ones (average $\mathrm{WH}=28 \mathrm{~m}, \mathrm{WL}=1.7 \mathrm{~km}$ and $\mathrm{LC}=$

$2.2 \mathrm{~km}$ ). The sediments show a distinct bottom echo with several internal weak reflections (echo subclass S2, Table 2). Showing no preferential direction, these bedforms suggest the occurrence of multidirectional bottom currents shaping the seafloor. They have been described as "small/medium-size bedforms with conformable sub-bottom reflections (W5)" by Breitzke et al. (2017).

\section{Anastomosed sediment waves}

Bedforms with a NW-SE preferential orientation, which changes to NNW-SSE, are mainly representative of the area $230 \mathrm{~km}$ south of the lles Eparses (Fig. 23, location in Fig. 11B). Additionally, a minor set of E-W bedforms with similar dimensions give to the area a kind of zigzag pattern. The E- 
W orientations seem to be more dominant northwestwards. The NW-SE sediment waves show a mean height (WH) of $73 \mathrm{~m}$, wavelength (WL) of $2.4 \mathrm{~km}$ and longitudinal length (LC) of $7.5 \mathrm{~km}$. The sediment waves are composed of high frequency and low amplitude reflections (echo sub-class S2, profile 1, Fig. 23). This train of sediment waves is cut to the NW by a $200 \mathrm{~m}$ deep flat-bottomed channel infilled by high-amplitude echo facies (profile 2, Fig. 23) evoking turbidites (echo sub-class S3, Table 2). The NW-SE dominant bedforms appears to belong to the "large steeped-sided beforms with hyperbolic refection pattern (W3)" of Breitzke et al. (2017), while the area dominated by NNWSSE bedforms could refer to the "arcuate bedforms" proposed by these authors.

\section{Discussion}

The Zambezi turbidite system comprises a channelized fan (with a wide and deep rectilinear, eroded valley and a coarse-grained distal depositional/erosional area) and a ponded semi-confined fan (Fig. 24) currently separated from the river outlet by $200 \mathrm{~km}$ and $90 \mathrm{~km}$, respectively. In contrast to transient fans (e.g. Gamberi and Rovere, 2011) and ponded basins (e.g. Madof et al., 2009), the lateral association of a ponded semi-confined fan with a channelized fan linked to the outputs of the same river has not yet, to our knowledge, been documented.

\subsection{Zambezi Fan morphometric characteristics compared to other fans}

Figure 25 illustrates the comparison of morphometric characteristics (width and relief) of systems at low latitudes and with different contexts (including the permanently connected Congo Fan, the disconnected during high sea-levels Amazon Fan, and the multisource Tanzanian Fan) and of the NAMOC.

From $400 \mathrm{~km}$ downstream, the relief of the Zambezi thalweg is higher in average than other turbidite systems especially from $600 \mathrm{~km}$ downstream and shows a greater variability. In contrast, from 200 to 
$400 \mathrm{~km}$, the relief of the Zambezi thalweg is closer to that of the Amazon Fan. The width of the Zambezi thalweg is higher than for more "classical" Congo fan (permanently connected valley with incised channels and levees) and Amazon fan (disconnected during high SL and connected, aggradational during low SL) and generally closer to the Tanzanian channel and NAMOC, which are disconnected during high SL and connected and erosional during low SL. The Zambezi thalweg aspect ratio (R/W) plotted as a function of average downchannel slope (Fig. 25C) also indicates a clear affinity with these systems. In the classification of Piper and Normark (2001) both the Tanzanian Channel and NAMOC belong to "type 4" fans (Skene and Piper, 2006; Bourget et al., 2008) that are characterized by high mainly muddy sediment inputs delivered by river or by glacier plumes. In contrast, the Congo and Amazon fans refer to "type 3" fans (Piper and Normark, 2001) that are fed by large rivers with high volume, muddy to sandy sediment supply.

As for the Zambezi Valley, (i.e. the V + U-shaped conduct, see Section 3.4), the width and relief are not comparable with other systems where such differentiation between a thalweg and a valley does not exist. Figure 25 demonstrates the significant difference in relief and width between the Zambezi Valley and the Tanzanian Channel and NAMOC systems; the Zambezi Valley being, on average, $200 \mathrm{~m}$ greater in relief and $10 \mathrm{~km}$ greater in width.

\subsection{Formative origins of the atypical Zambezi Valley}

The differences in relief and width of the valley and thalweg of the Zambezi Valley could indicate that the shaping agents of both features do not refer to similar processes. The size (cross-sectional area, Fig. 9E) of the thalweg and the presence of several generations of incisions on the floor (Figs. 14 to 16) are coherent with the hypothesis of an erosional activity of turbidity currents.

In contrast the relief and width of the entire valley, with flanks affected by lineations parallel to the valley evoking outcropping strata (e.g. Fig. 17), appears far too high to be entirely shaped and maintained solely by turbidity currents. Therefore, the exceptional dimensions of the valley are suggested to refer to other, probably combined, causes such as the age of the valley in link with the 
feeding evolution of the fan, the imposed stability of the valley course by physiographic constraints and the flank erosion by powerful bottom circulation.

The N-S portion of the valley is a composite feature that was initiated during the Oligocene (Droz and Mougenot, 1987; Ponte, 2018), in link with the feeding by Serpa Pinto Valley and remained active after the Miocene shift to the NW-SE upper portion of the Zambezi Valley. The longer activity duration of the N-S portion of the valley is a possible cause for its great relief from $400 \mathrm{~km}$ to $850 \mathrm{~km}$ (Fig. 9C). It must be noticed that the Serpa Pinto confluence is located near a faulted zone (Figs. 1, 16) (Deville et al., 2018) and faulting could have had a role on the valley relief. However, the impact of the fault zone is only observed locally in the valley around $450 \mathrm{~km}$ (Fig. 16) and therefore it is considered as not responsible to the drastic increase of the valley relief.

In addition, downstream the Serpa Pinto confluence, the Zambezi Valley is constrained by lateral morpho-tectonic features, i.e. the southern portion of the Davie Ridge and the Madagascar margin to the east and the carbonate platforms (lles Eparses and seamounts) to the west. Similarly, Fournier (2016) attributes the large width of the Tanzanian Channel (Fig. 25B) to the confinement by tectonic features resulting in the stabilization of the channel and consecutive strengthening of flows inside it. In contrast, more classical, unconfined deep-sea fans (e.g. the Congo, Amazon, Cap Timiris, or Angola channels, Wynn et al., 2007) show typical tree-like organizations, linked to recurring lateral channel migrations.

Lastly, using a hydrodynamic ROMS model, Miramontes et al. (2019) demonstrated the presence of strong bottom current velocities (up to $20 \mathrm{~cm} / \mathrm{s}$ mean and up to $60 \mathrm{~cm} / \mathrm{s}$ max) along the Zambezi Valley flanks (Fig. 26), suggested to be able to erode the flanks and to contribute to the widening of the valley. From Miramontes et al. (2019), these bottom currents are related to the retroflected southward flowing portion of the NADW. Marchès et al. (2007) documented similar downslope enlargement of the Portimão canyon (Gulf of Cadiz) caused by the combination of downslope gravity processes and the deep Mediterranean Outflow Water current. The presence of sediment waves 
(shown in Fig. 20 to 23 and previously identified by Breitzke et al., 2017) is a further evidence of bottom current activity in the area. These bedforms are all located in areas where the mean velocities are lower than $10 \mathrm{~cm} / \mathrm{s}$ (Fig. 26B), which are favorable to deposition by bottom currents (Miramontes, 2016). Generation of large sediment waves by bottom currents in unconfined settings is, for example, also found in the eastern Equatorial Pacific (Lonsdale and Malfait, 1974), in the Argentine Basin (Flood and Shor, 1988), in the western South Atlantic (Cunningham and Barker, 1996) and offshore NW-Svalbard (Hustoft et al., 2009; Forwick et al., 2015)..

\subsection{Turbiditic overflows from the Zambezi Valley?}

Fine-grained levee deposits are scarcely observed close to the Zambezi Valley. A possible explanation for this is the winnowing of the upper fine-grained portion of turbidity currents by the strong, deep oceanic currents that flow inside the valley (Figs. 2, 26). This pirating process was also invoked in the Tugela Fan (Natal Valley, South Africa) to explain the stunted development of the fan (Wiles et al., 2013).

In the Zambezi Fan, only 4 zones of S3 or S4 echo facies (interpreted as fine-grained turbidites, Fig. 11B) are present at the right-hand side (western) and at the mouth of the Zambezi Valley.

Breitzke et al. (2017) propose that the echo facies S3 on the right-hand side of the valley just downstream of the Tsiribihina confluence results from overflow of turbidity currents from the Zambezi Valley. However, at this location turbidity currents should be $\geq 750 \mathrm{~m}$ thick to be able to overflow from the valley (Fig. 9C). Direct information on turbidity current thicknesses in the Zambezi Fan is lacking. However, turbidity currents thicknesses of 100 to $400 \mathrm{~m}$ are classically reported in the literature (Nelson, 1983; Damuth and Flood, 1985; Nakajima et al., 1998; Migeon, 2000; Migeon et al., 2001; Babonneau et al., 2002; Ercilla et al., 2002; Curray et al., 2003; Deptuck et al., 2003; Pirmez and Imran, 2003; Bourget et al., 2011; Babonneau et al., 2012). Higher thicknesses (600 to $1000 \mathrm{~m}$ ) are not frequently reported (Normark et al., 1980; Stow and Bowen, 1980; Piper and Savoye, 1993; Mitchell, 2014). 
A minimum thickness of $600 \mathrm{~m}$ (i.e. relief of the valley) is estimated in the Tsiribihina Valley ca. $80 \mathrm{~km}$ upstream the confluence, where sediment waves of turbiditic origin are observed and testify of overflow processes (Fig. 17).

The knickpoint found at the junction with the Zambezi Valley (Fig. 10A, zoom) might cause a hydraulic jump that could thicken the current by 1.5 (Muck and Underworld, 1990) to $900 \mathrm{~m}$, which is sufficient for local deposition of fine-grained levee sediments by overflow. Another mechanism that could enhance the resulting current thickness is the interaction or addition of turbiditic flows at the Zambezi and Tsiribihina confluence, as described by Babonneau et al. (2012) in the Kramis Fan.

Other zones of fine-grained stratified deposits are encountered distally where the Zambezi Valley widens and shallows to about $50 \mathrm{~m}$ (Fig. 11, 19A). On the right hand side of the valley, an ancient rather classical channel-levee system (Fig. 18B) attests to a previous (not dated) phase when aggradational and overflow processes where more active than today, which is dominated by erosional processes. On the left hand side of the valley, two other zones of fine-grained turbidites possibly relate to inputs from southern Madagascar.

\subsection{Supply of the Zambezi fan and Mozambican ponded fan}

Canyons observed on the upper slope (Jouet and Deville, 2015) and valleys identified on the lower slope by Wiles et al. (2017a) appear under-sized and barely compatible with the high sediment load of the Zambezi River (48 x 106 t/yr, Milliman and Syvitski, 1992). Therefore, the connections and paleo-connections from the river to the different elements of the turbidite systems are still not understood.

According to Schulz et al. (2011), and based on sediment rates calculated from cores on the Mozambican slope, the channelized and ponded semi-confined fans would alternate their activity as a function of the relative sea-level: the channelized fan would be fed by the Zambezi inputs during periods of high sea-level, when the littoral drift transports the inputs towards the Northeast and deposit the inner belt on the shelf (Beiersdorf et al., 1980; Schulz et al., 2011); the ponded fan would 
be supplied during periods of low sea-level through the canyons and channels on the continental slope facing the Zambezi delta. Contradictorily, Wiles et al. (2017a) propose that, during high sealevels, sediments of the present-day inner mud belt are dominantly transported towards the Angoche Basin (Fig. 1), i.e. further north than the hypothesis of Schulz et al. (2011) and can therefore more difficultly feed the Zambezi Valley. Wiles et al. (2017a) suggest that the Zambezi Valley would be supplied during lowering of sea-levels. These contradictory assumptions on the timing of feeding of the northwestern and southeastern parts of the margin (Schulz et al., 2011; Wiles et al., 2017a) show that the question of the feeding time of both fans is not resolved yet. Moreover, very high sediment rate (average of about $1 \mathrm{~m} / \mathrm{ky}$ for the last $120 \mathrm{ky}$ ) calculated at IODP Core U1477 (Fig. 11A) on the upper Mozambique slope in the extension of the Zambezi delta (Leg 361, Hall et al., 2016) suggests that this area remained a preferential site of deposition during low and high sea-levels of the last climatic cycle. However, a Holocene sediment rate of $0.2 \mathrm{~m} / \mathrm{ky}$ was calculated from a PAMELA core (Jouet and Deville, 2015) close to U1477, indicating that supply to this part of the margin varied drastically and that a more detailed stratigraphy of core U1477 is needed to specify the supply of the Mozambican slope during high and low sea-levels.

In the present state of this study, the stratigraphic relationships (synchronicity or diachronism?) between the Zambezi fan and the ponded fan is unknown and our results do not bring decisive arguments to choose between these previous findings (Schulz et al., 2011; Wiles et al., 2017a). Incisions of the Zambezi thalweg (Figs. 14 to 17) are arguments towards recently (currently?) active turbidity currents in the Zambezi Valley, in agreement with the proposition of Schulz et al. (2011). In contrast, moorings in the distal Zambezi Valley (MLP5 and MLP8, Miramontes et al., 2019) did not registered turbidity currents over two years (November 2014 to January 2017), indicating a presentday inactivity of the Zambezi Fan, or at least that the Zambezi Fan is not presently a very active fan, favoring the hypothesis of Wiles et al. (2017a) of a low supply during high stand of sea-level. Moreover, in addition to the shelf circulation that probably influence the feeding of both fans, the Mozambique Current formed on the upper Mozambican slope by southward moving eddies (Walford 
et al., 2005), probably also contributed to the feeding of the ponded fan by pirating inputs of the Zambezi Valley during high and low sea-level stands. This pirating process was also proposed by Wiles et al. (2013) in the Tugela Canyon (Natal Valley).

Additional sedimentological, architectural and stratigraphical information is needed to conclude on the question of the timing of sediment supply to the Zambezi turbidite system.

\section{Conclusions}

The Zambezi turbidite system consists in two architecturally different fans, for which the respective timing of feeding and activity (either erosional or depositional) is not yet established. The Zambezi Fan is a channelized fan mainly composed of the Zambezi Valley, its Madagascan tributaries and a wide distal depositional area. A ponded semi-confined fan (in the Intermediate Basin) is present on the Mozambique rise, westwards from the Zambezi Valley. Main results from this bathymetric and high-resolution seismic study are:

- The Zambezi Fan is a multiple sources fan in which the precise contribution of the Zambezi and Madagascar rivers is not yet quantified. Evidences of intense erosion observed along the entire length of the Zambezi Valley and depositional area indicate that erosive processes were widely active in the recent (current?) time. The Zambezi Valley is composed of a Ushaped thalweg with dimensions comparable to the Tanzanian Channel and NAMOC and an over-sized V-shaped valley more than three times as deep and wide compared to the thalweg. These extreme proportions of the thalweg and valley suggest erosive processes from both turbidity currents in the thalweg and oceanic bottom currents on the upper flanks of the valley.

- Presently, the deep entrenchment of the Zambezi Valley limits the overflow of turbidity currents and fine-grained sediments (levees) are mostly absent. The principal sediment accumulation occurs distally from the mouth of the Zambezi Valley and consists mainly of coarse-grained terminal lobes. A single channel-levee system at the mouth of the Zambezi 
Valley witnesses an "anomalous" aggradational growth pattern in the distal Zambezi Fan. This episode of aggradational deposition, although not accurately dated, is older than the present-day thalweg.

- The semi-confined fan (in the Intermediate Basin) is infilled with sheet-like, coarse-grained turbidites and ponded, fine-grained turbidites.

The Zambezi turibidite system, therefore, appears unique in terms of (i) association of 2 separated maybe alternating depocenters, (ii) exceptionally great dimensions of the Zambezi Valley, (iii) recent (current?) widespread erosion and (iv) mainly coarse-grained deposits in the valley and depositional area. These specificities are thought to be largely controlled by erosion/deposition activity of combined turbiditic and oceanic currents.

\section{Acknowledgments}

The PhD thesis of Ruth Fierens, post-doctoral fellowship of Elda Miramontes and Master thesis of Steven Landurain were co-funded by TOTAL and IFREMER as part of the PAMELA (Passive Margin Exploration Laboratories) scientific project. The PAMELA project is a scientific project led by Ifremer and TOTAL in collaboration with Université de Bretagne Occidentale, Université Rennes 1, Université Pierre and Marie Curie, CNRS and IFP-EN.

We thank the Captains and crew members of the 2014 and 2015 cruises PTOLEMEE, PAMELA-MOZ1 and PAMELA-MOZ2 onboard the R/V L'Atalante and PAMELA-MOZ4 onboard of R/V Pourquoi pas? and the technicians from Genavir that ensured acquisitions of the geophysical data. The onboard scientific teams of PAMELA surveys are greatly thanked for their contribution to data acquisitions. Seismic data were analyzed using Kingdom Suite software, kindly made available to UBO by IHS in the framework of their Educational Grant Program. We greatly acknowledge the reviews from the Editor in Chief Zhongyuan Chen, from Dr. Errol Wiles and from an anonymous reviewer who greatly helped improving the paper. 


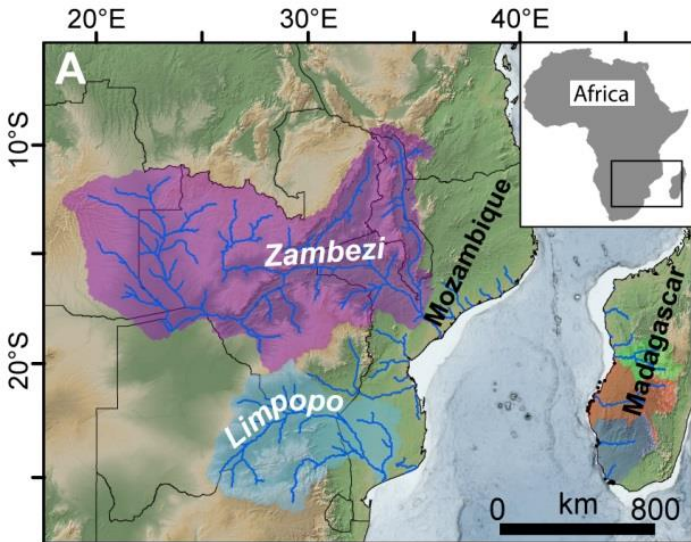

Shelf dynamics

$>$ Inner and outer mud belt (1)

Sedimentary features

Turbiditic features

Distal depositional area (2)

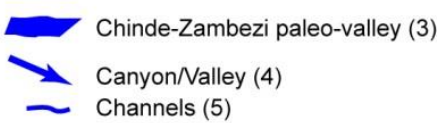

Contouritic features

Sediment waves (6 \& 7)

Drifts (5, 8 \& 9)

Moat (5)

Oligocene contouritic ridge (10)

Modern drift (10)

\section{Structural features}

Aivis Beira High (11)

Davie Ridge (12)

Fractured zone (13)

. Buried prolongation of

- Davie Ridge (12)

- Late Miocene doming (14)

$\ldots$ Scarps

.- Structural lineaments (7)

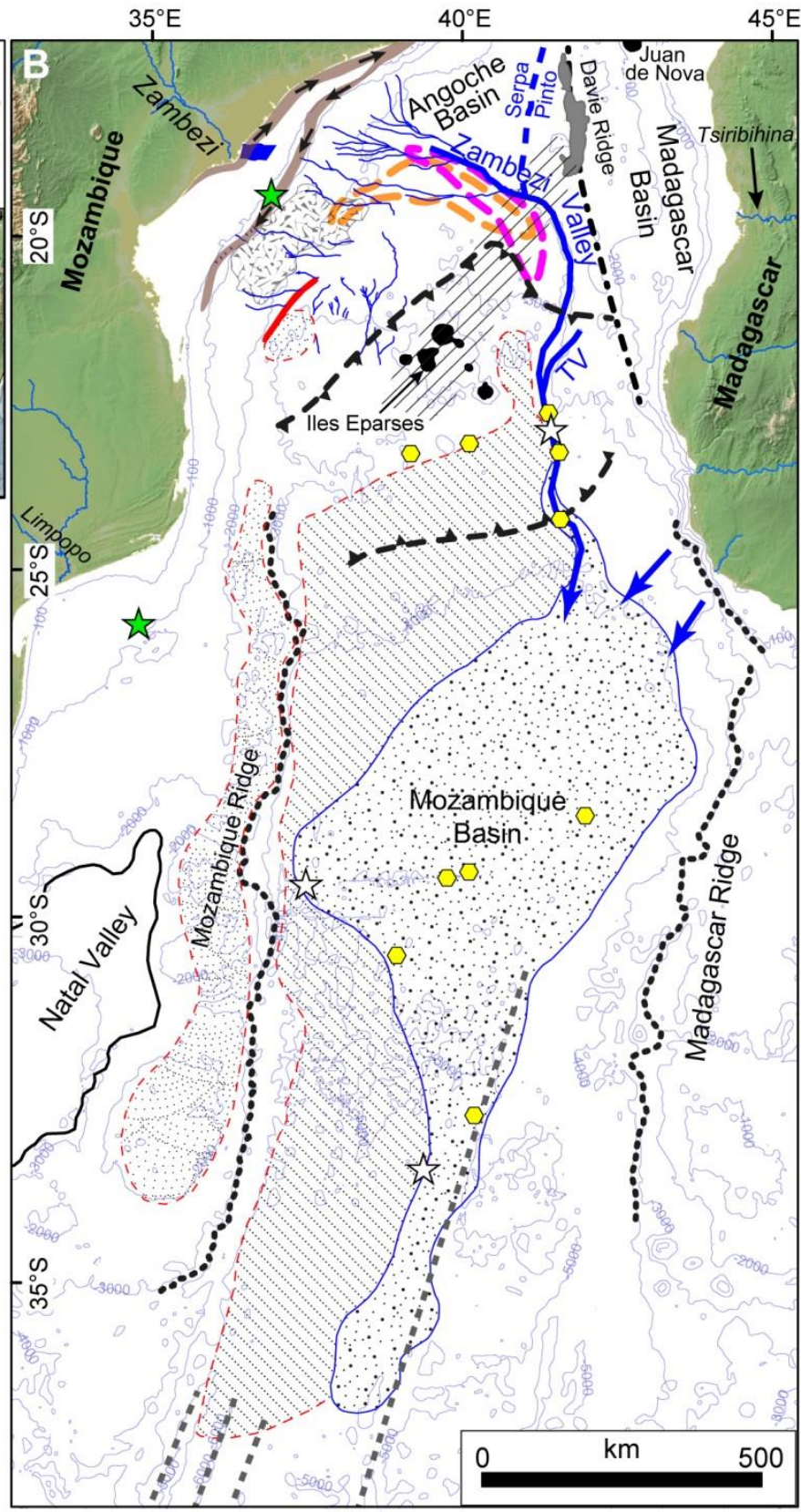

Figure 1 ( 2 columns) 


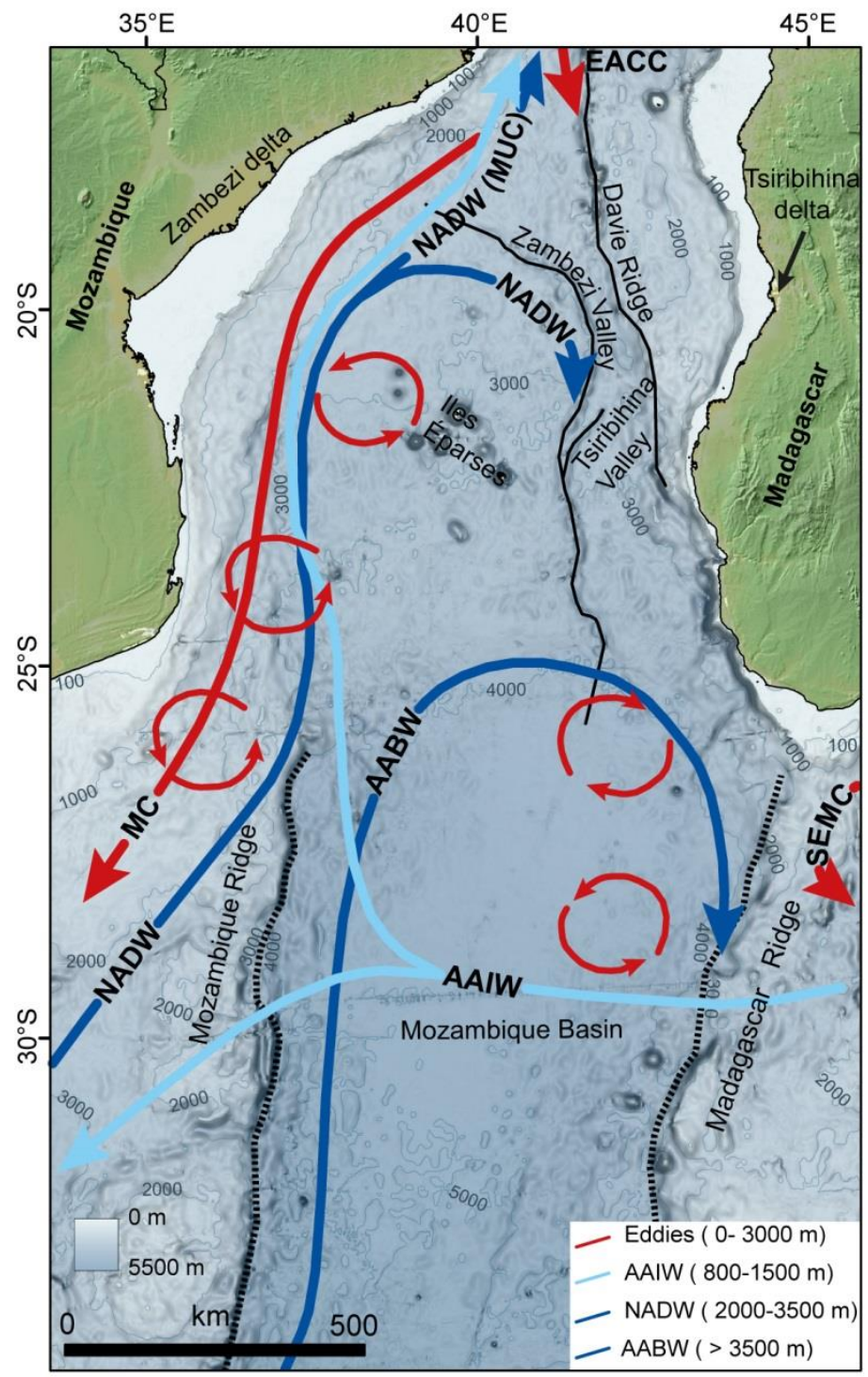

Figure 2 (1.5 column) 


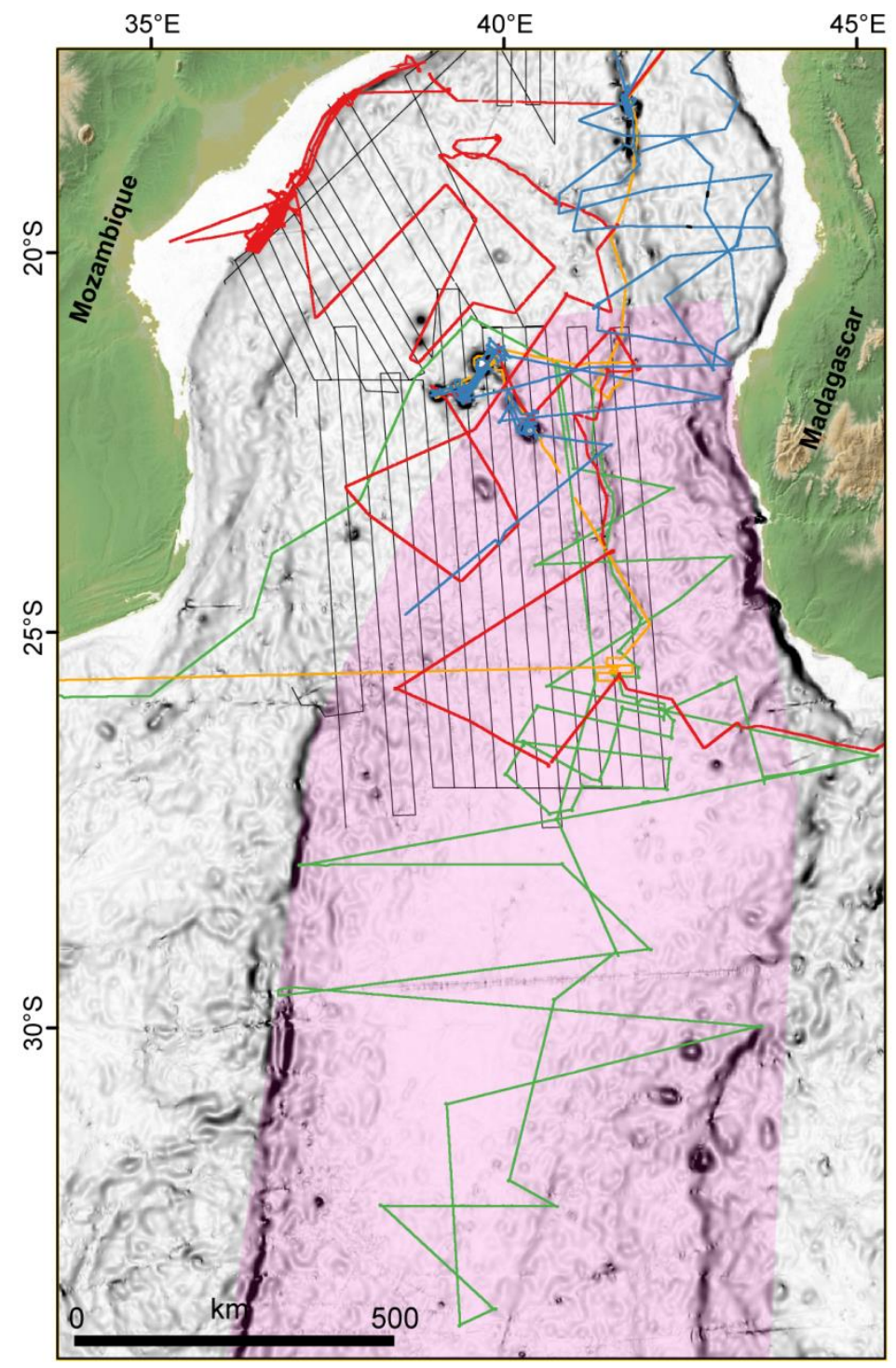

Figure 3 (1.5 column) 


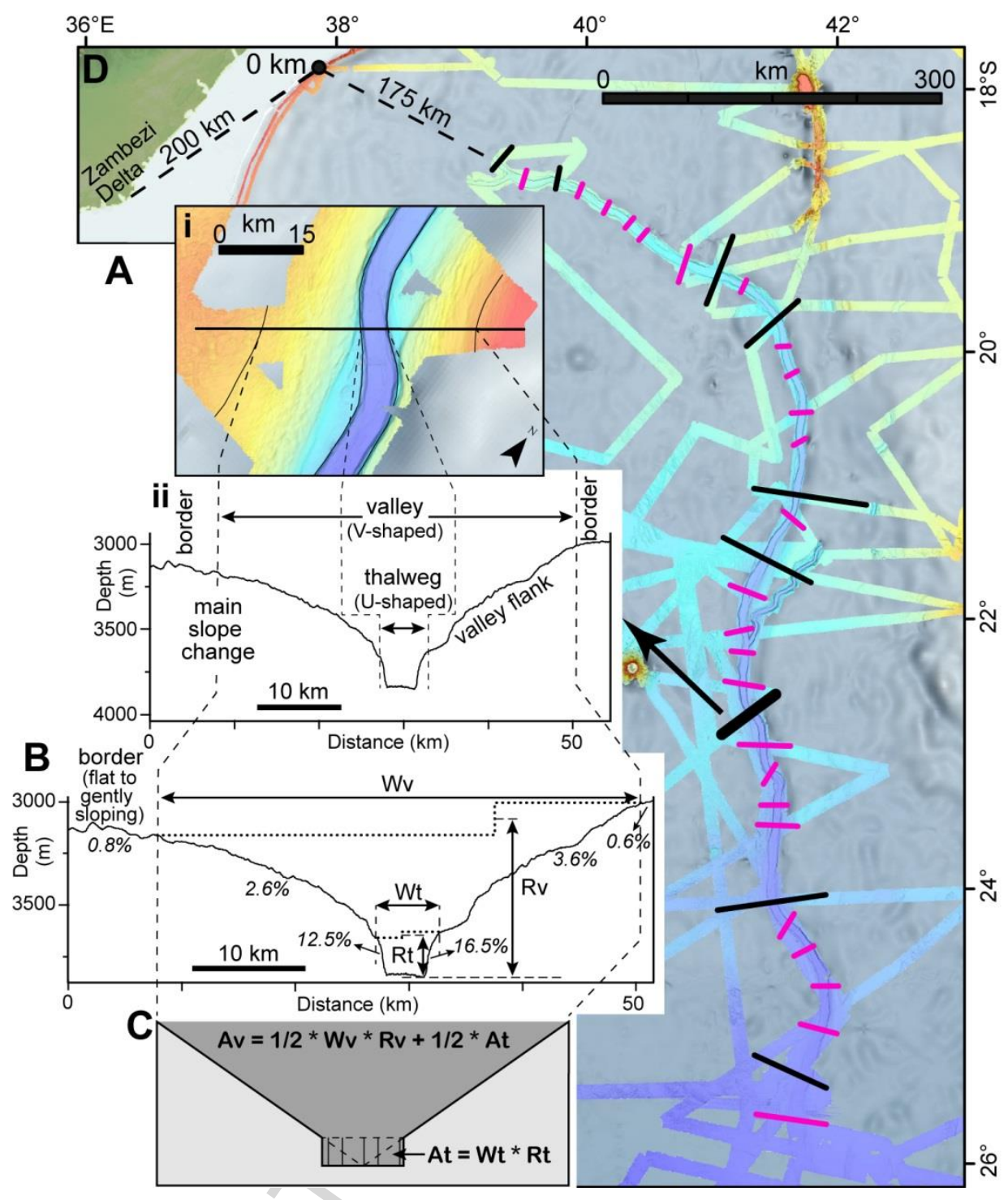

Figure 4 ( 1.5 column) 


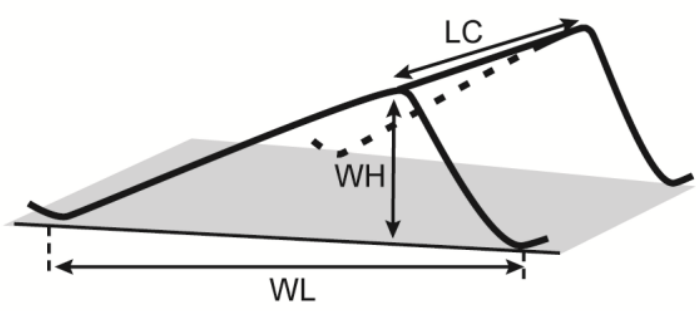

Figure 5 ( 1 column) 
B<smiles>[CH][CH]</smiles>

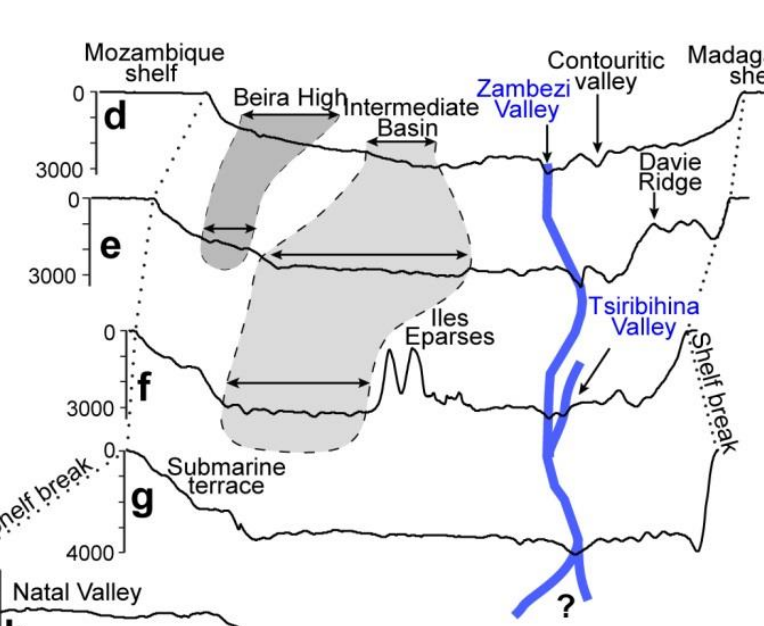

Mozambique
shelf

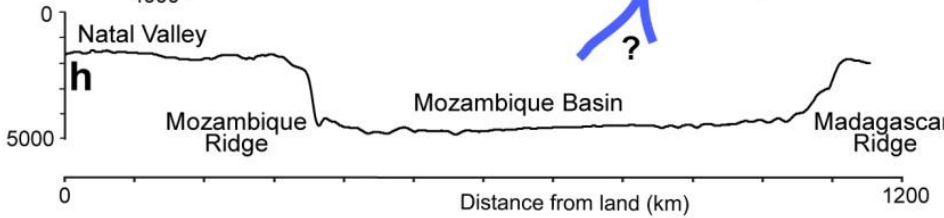

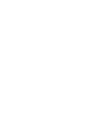
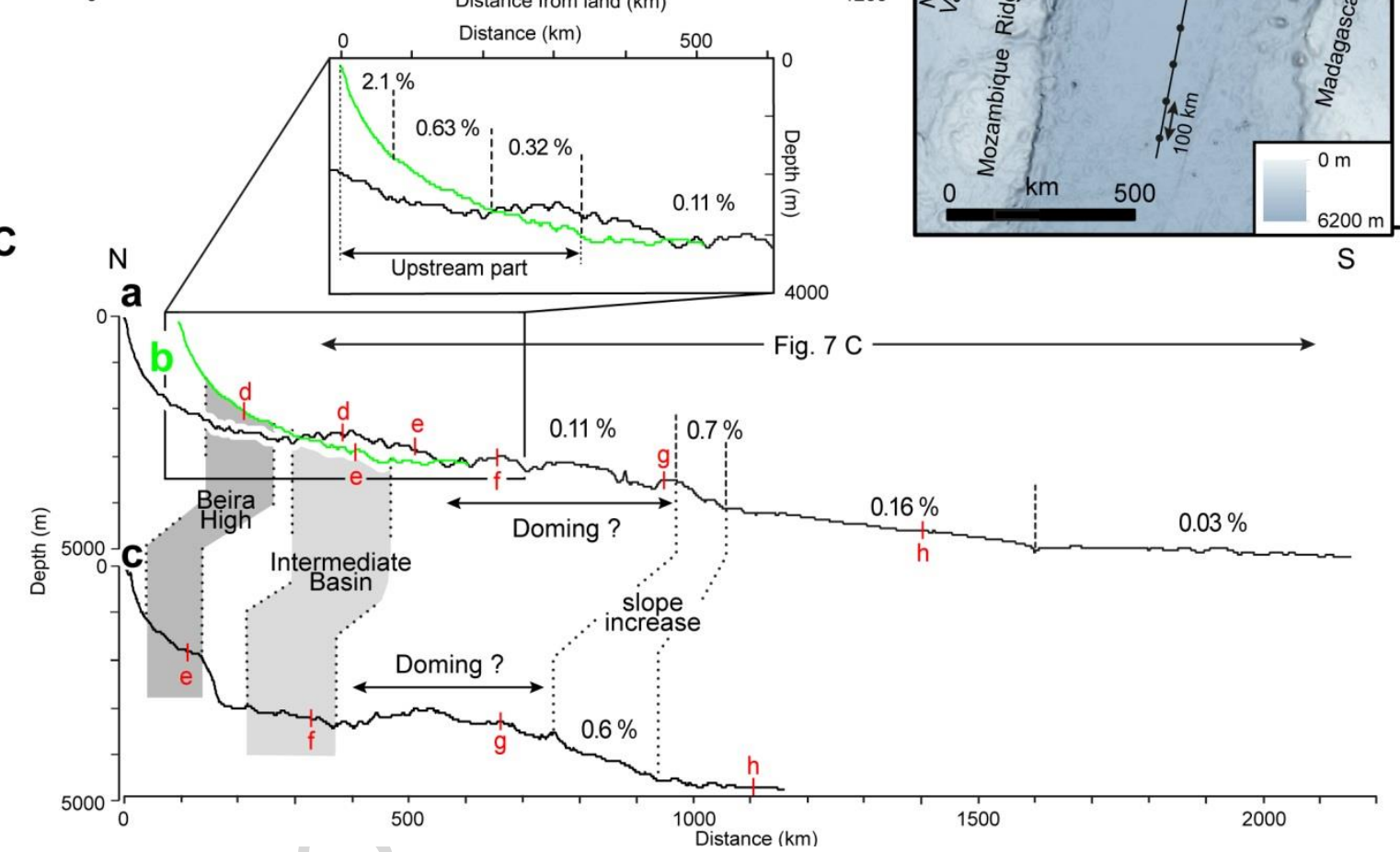

Figure 6 ( 2 columns)

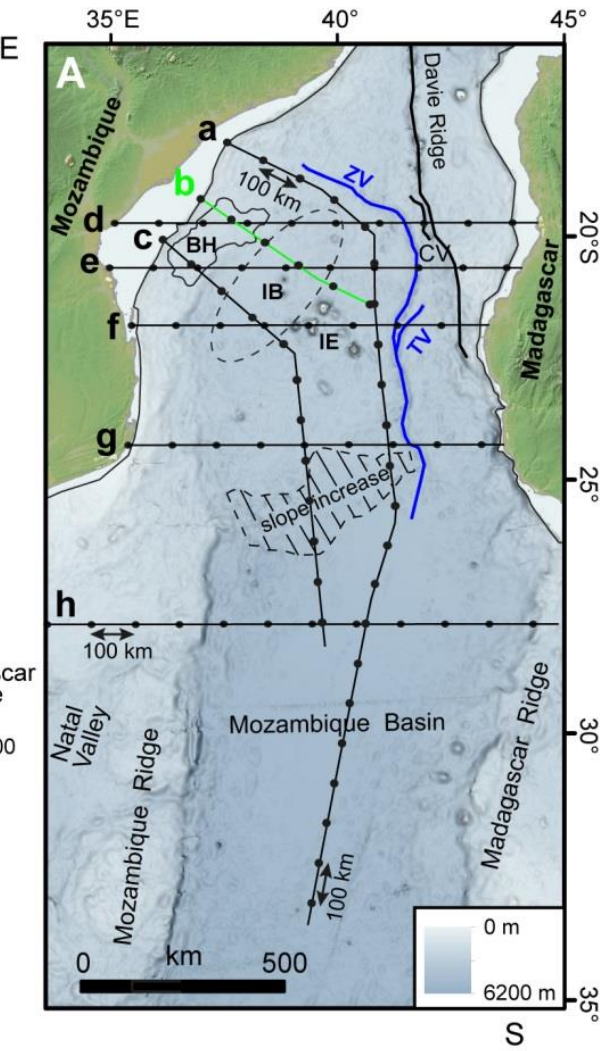

$$
\text { N }
$$



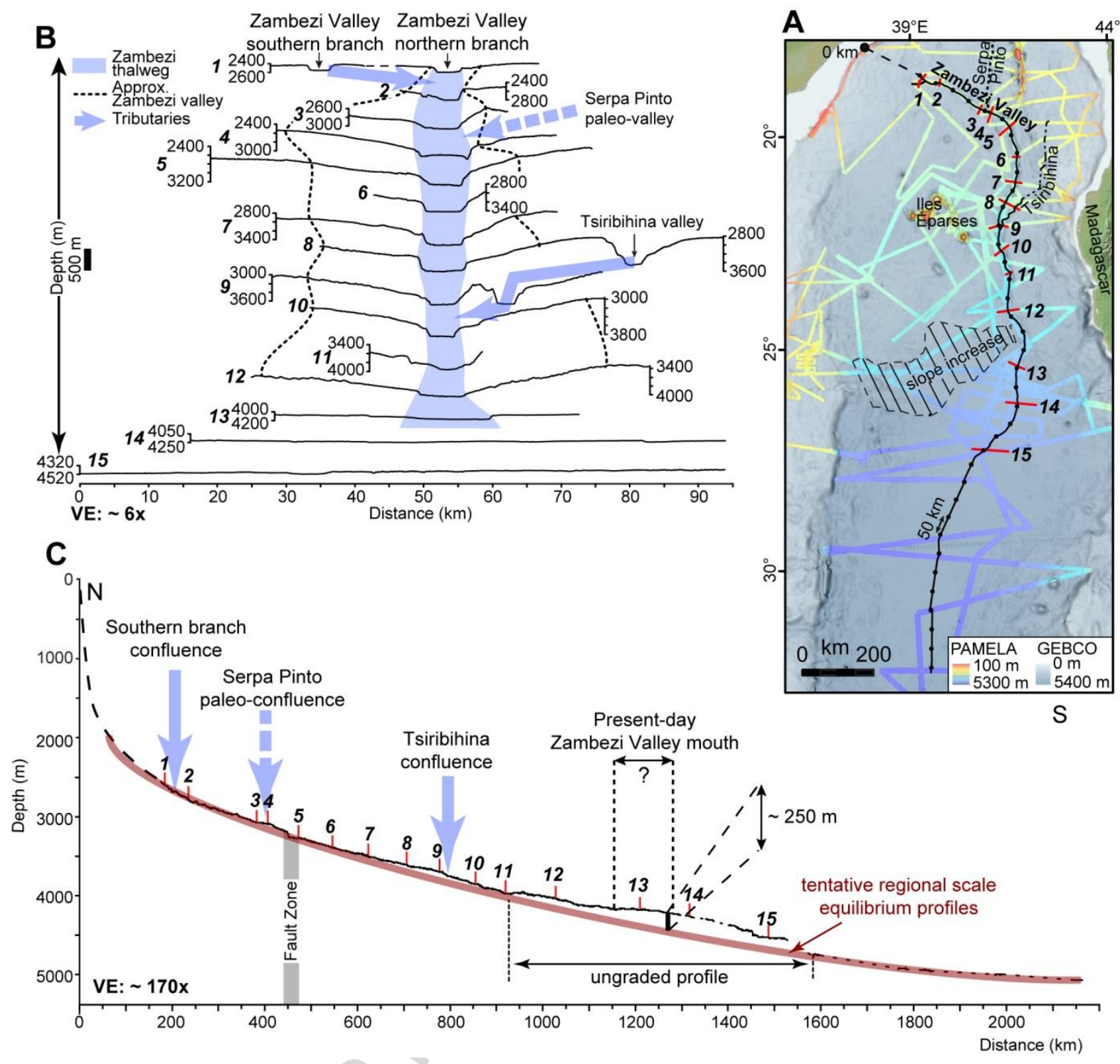

Figure 7 ( 2 columns) 


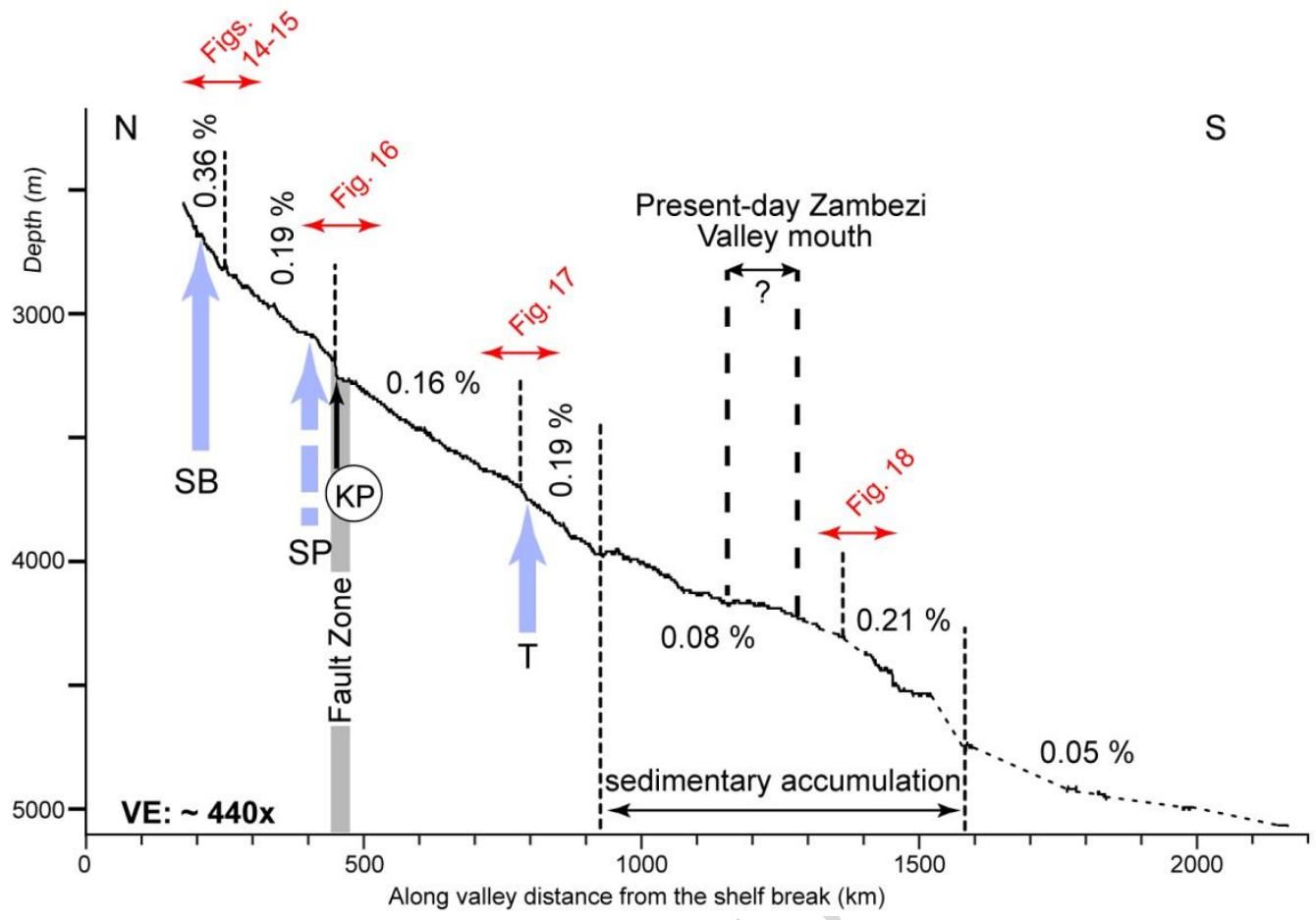

Figure 8 (1.5 column) 

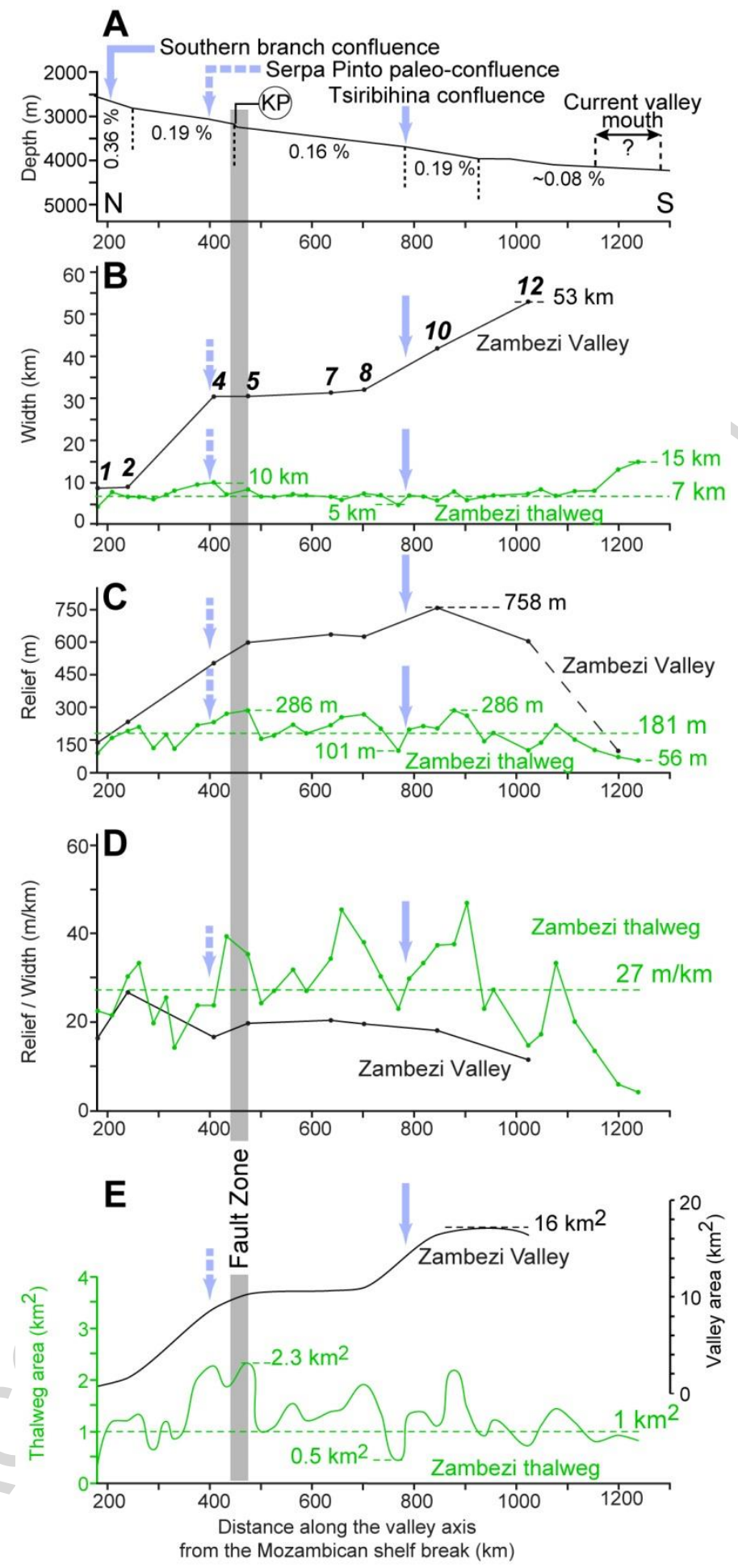

Figure 9 ( 1 column) 


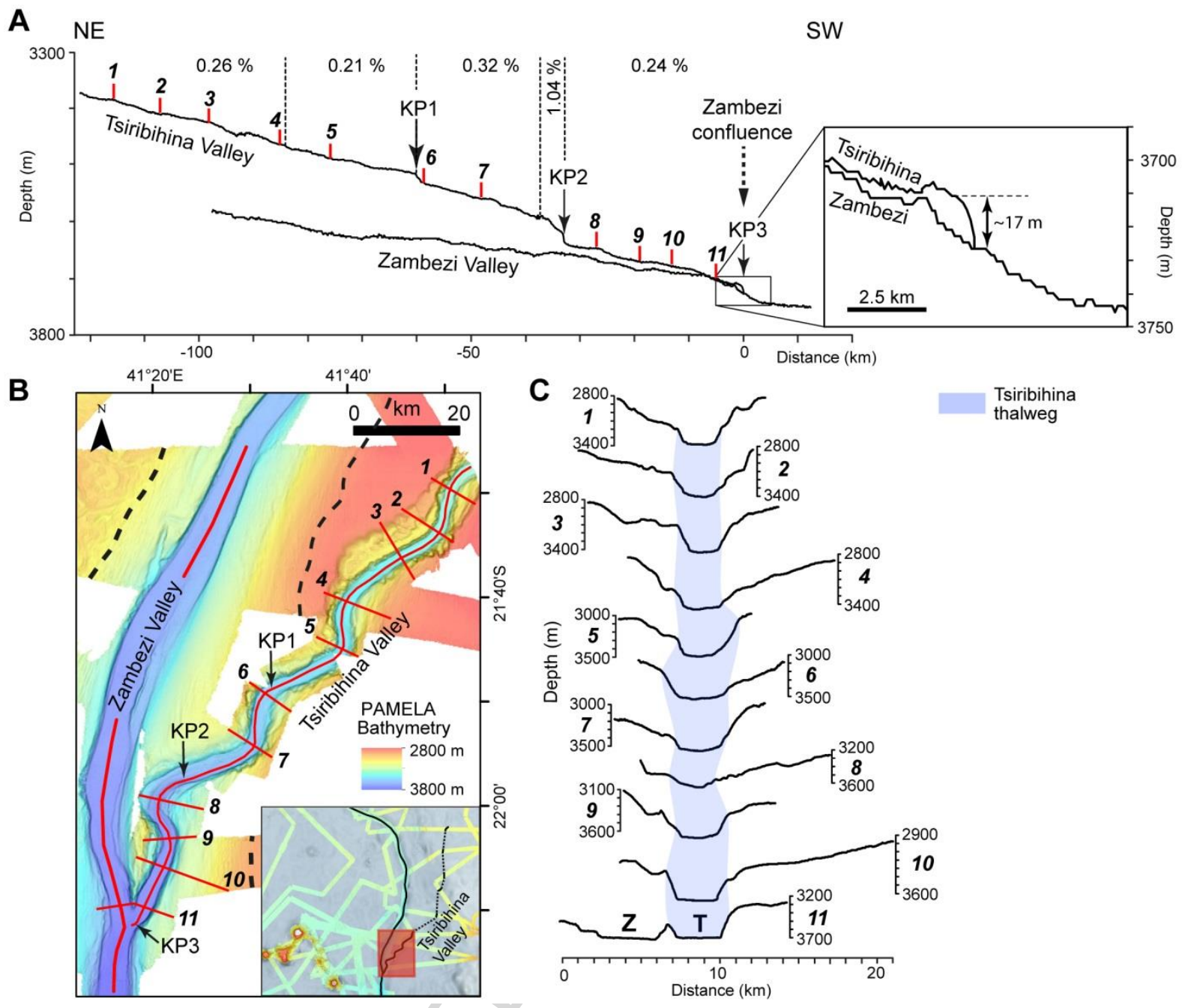

Figure 10 ( 2 columns) 


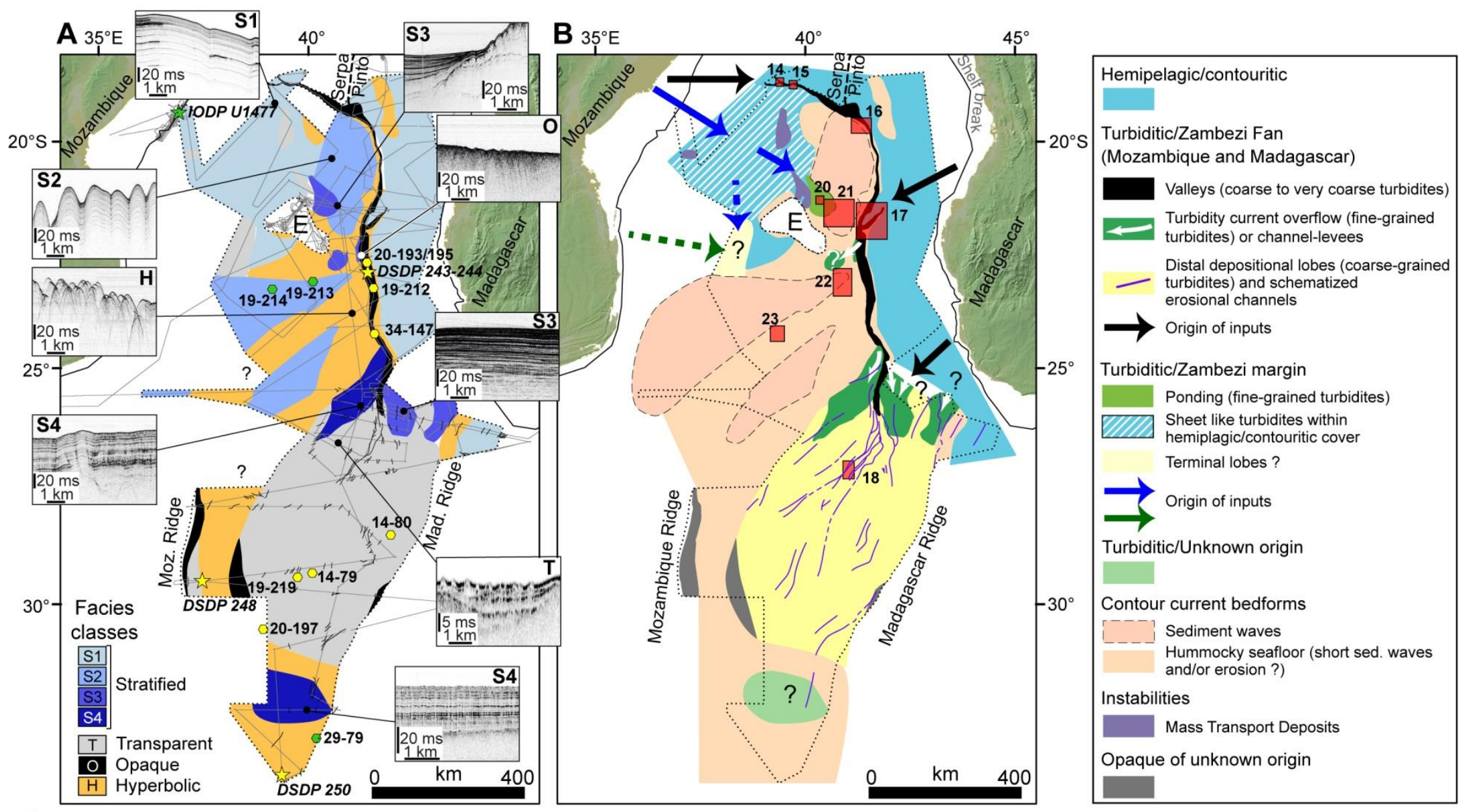

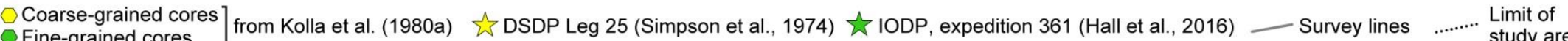

Figure 11 ( 2 columns) 

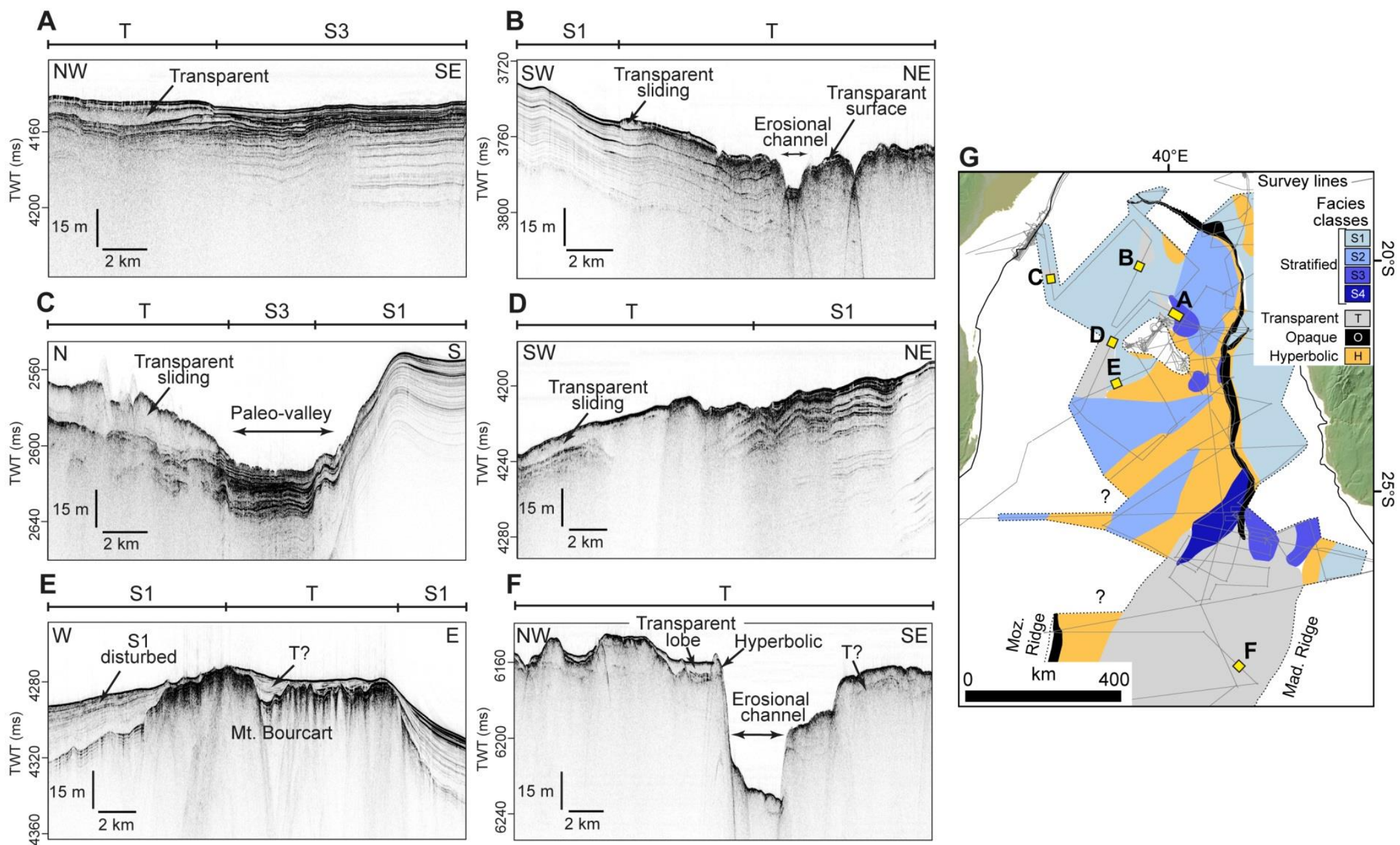

Figure 12 ( 2 columns) 

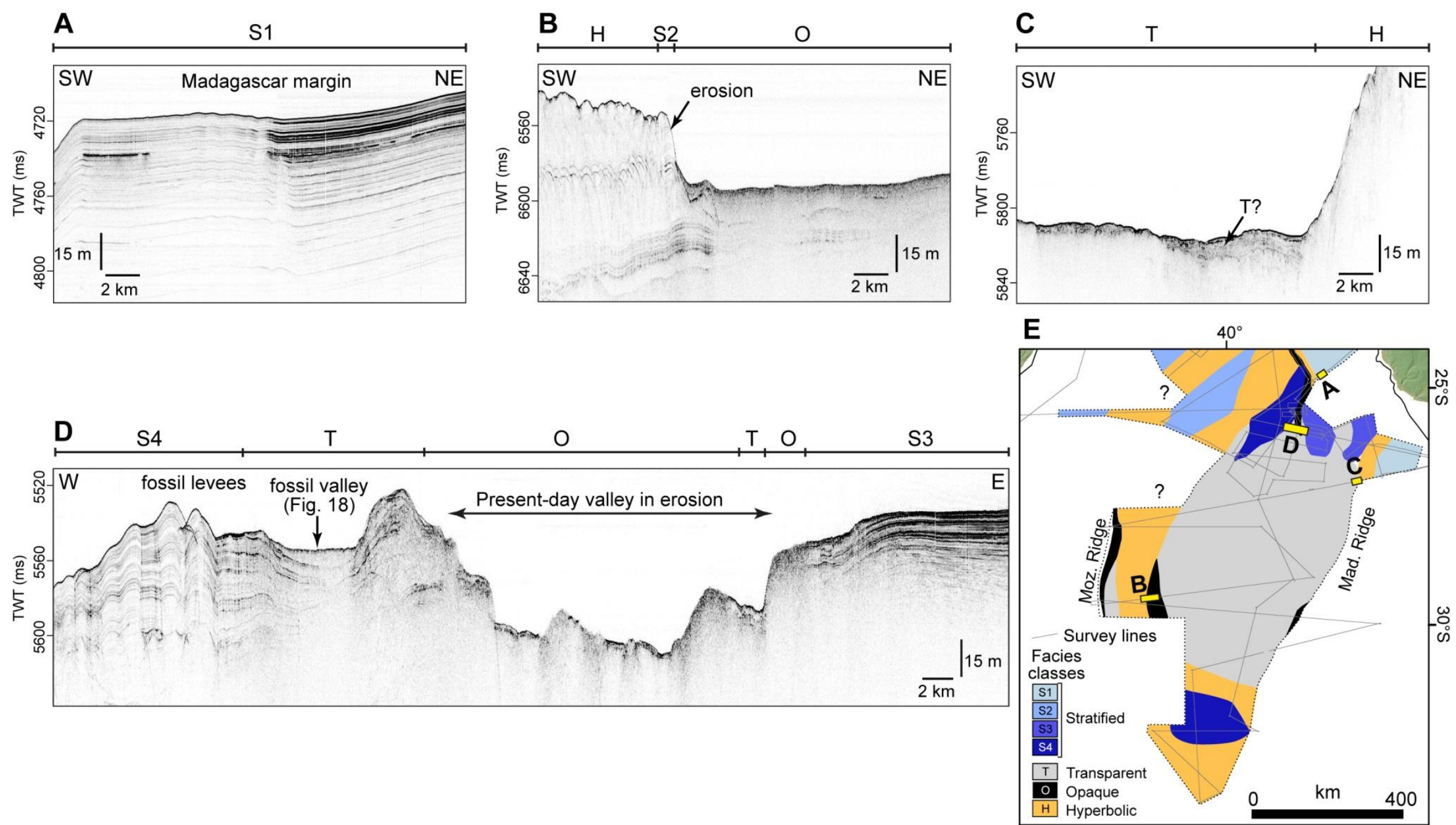

Figure 13 ( 2 columns) 

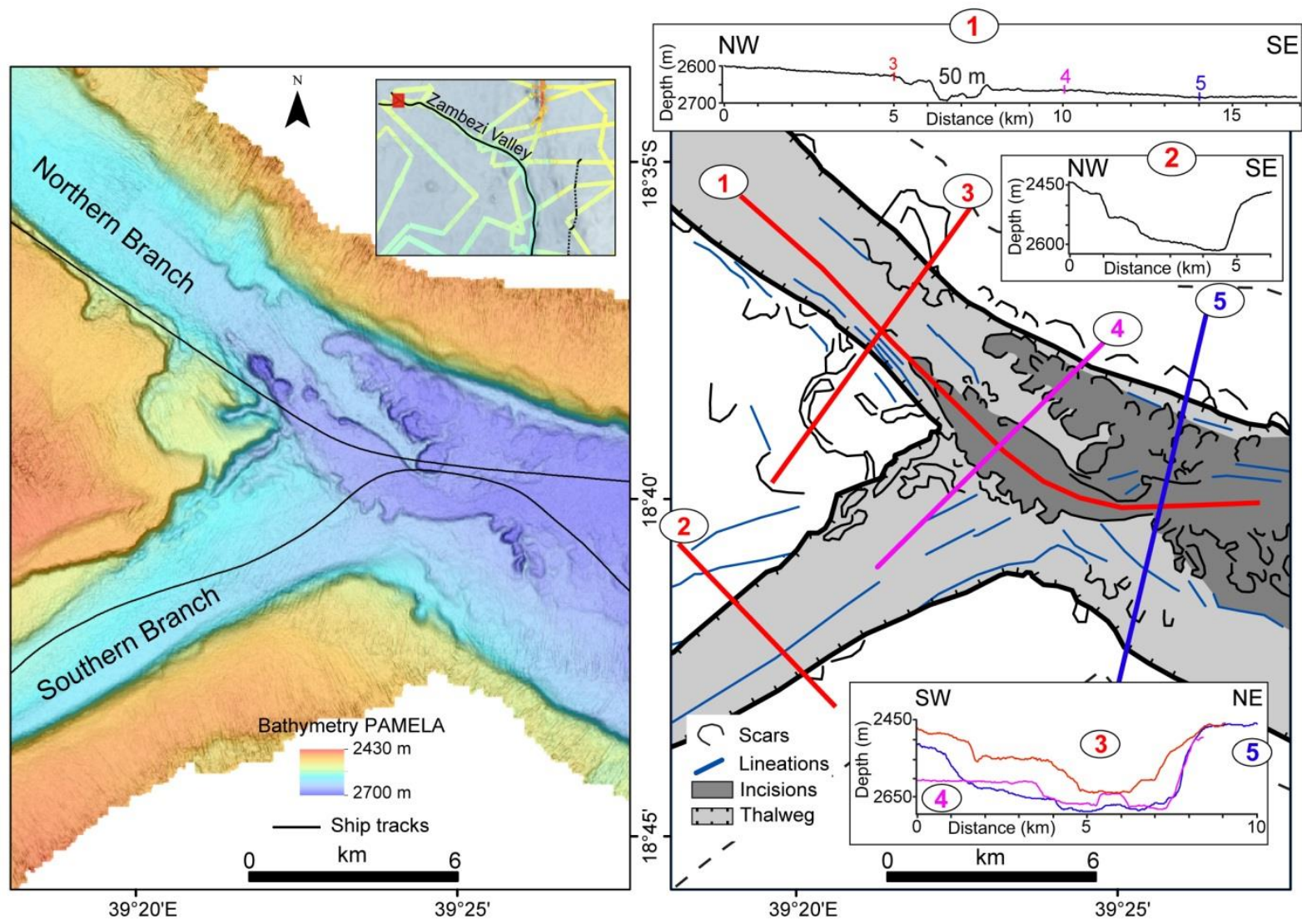

Figure 14 ( 2 columns) 


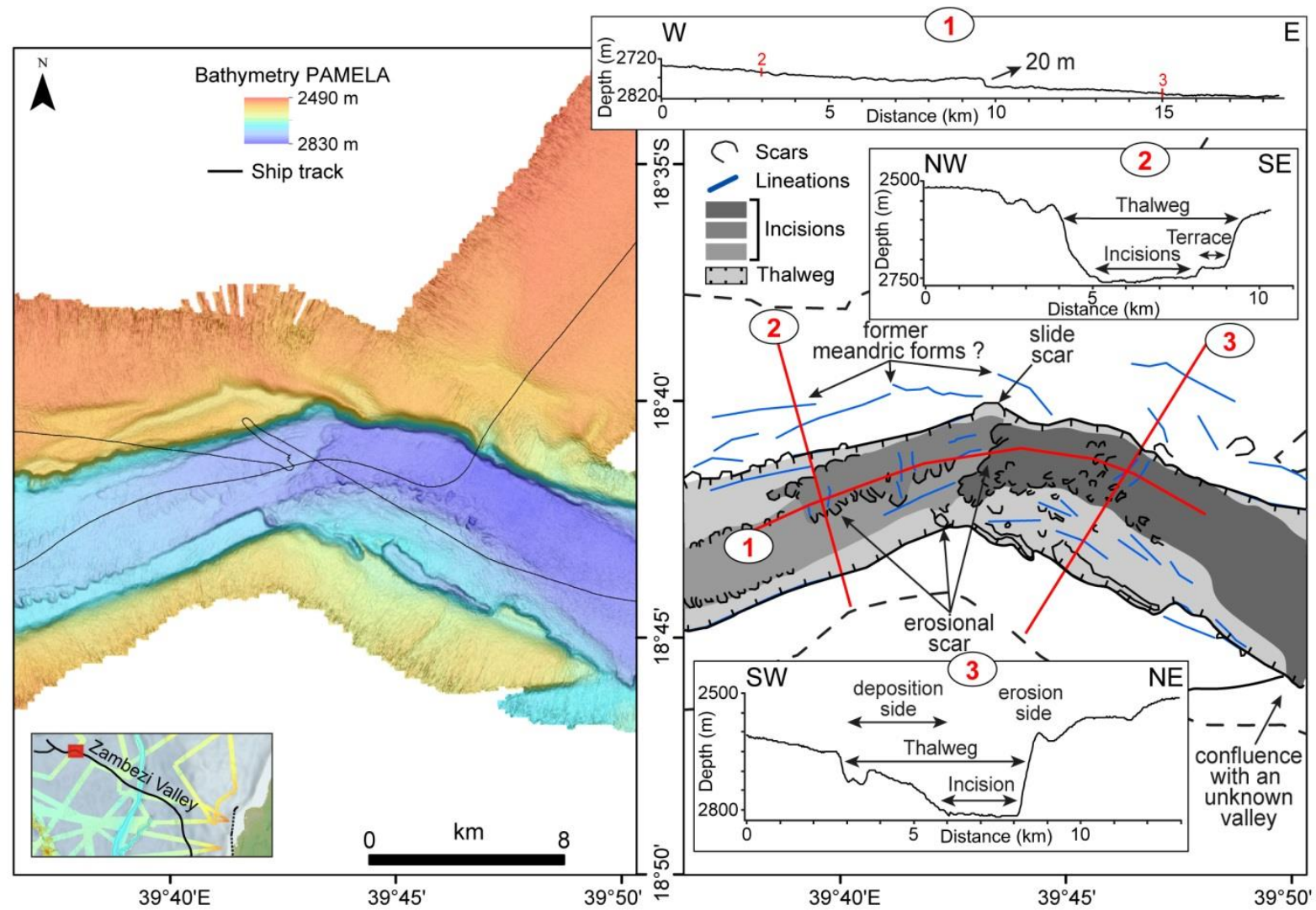

Figure 15 (2 columns) 
A

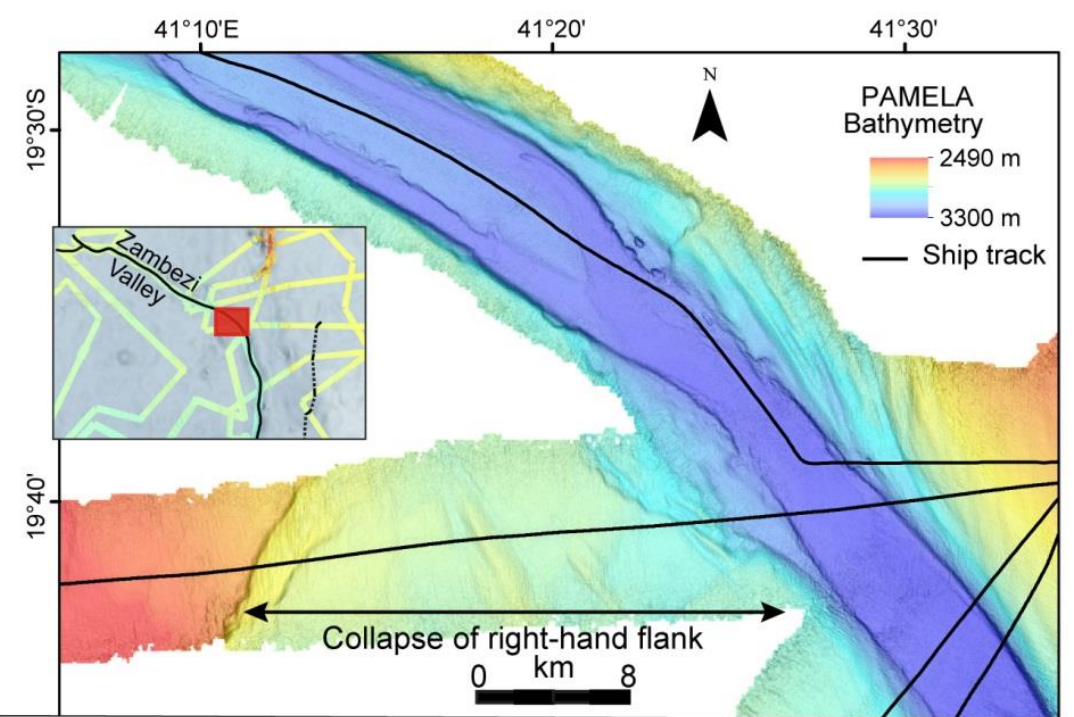

B
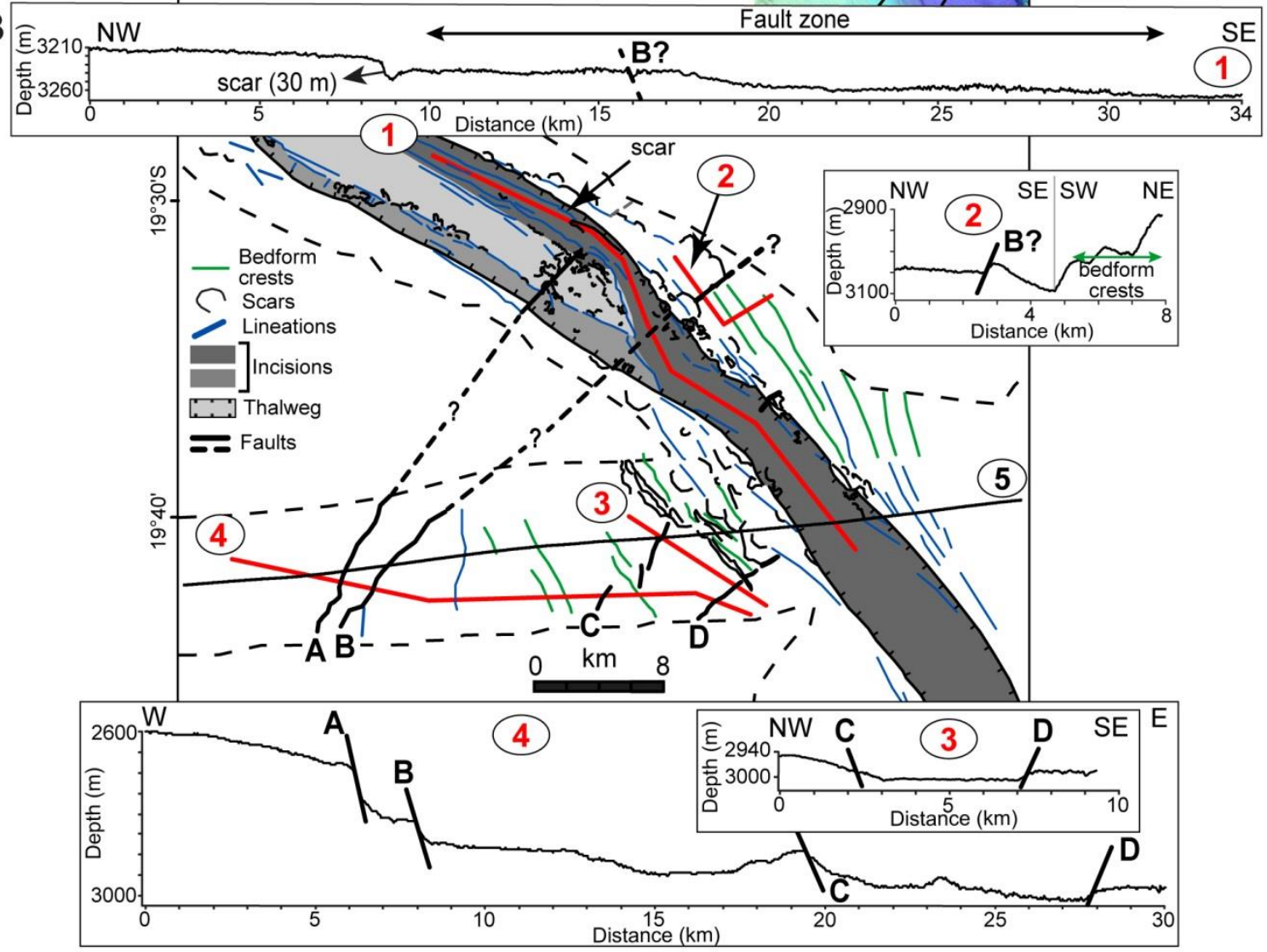

C

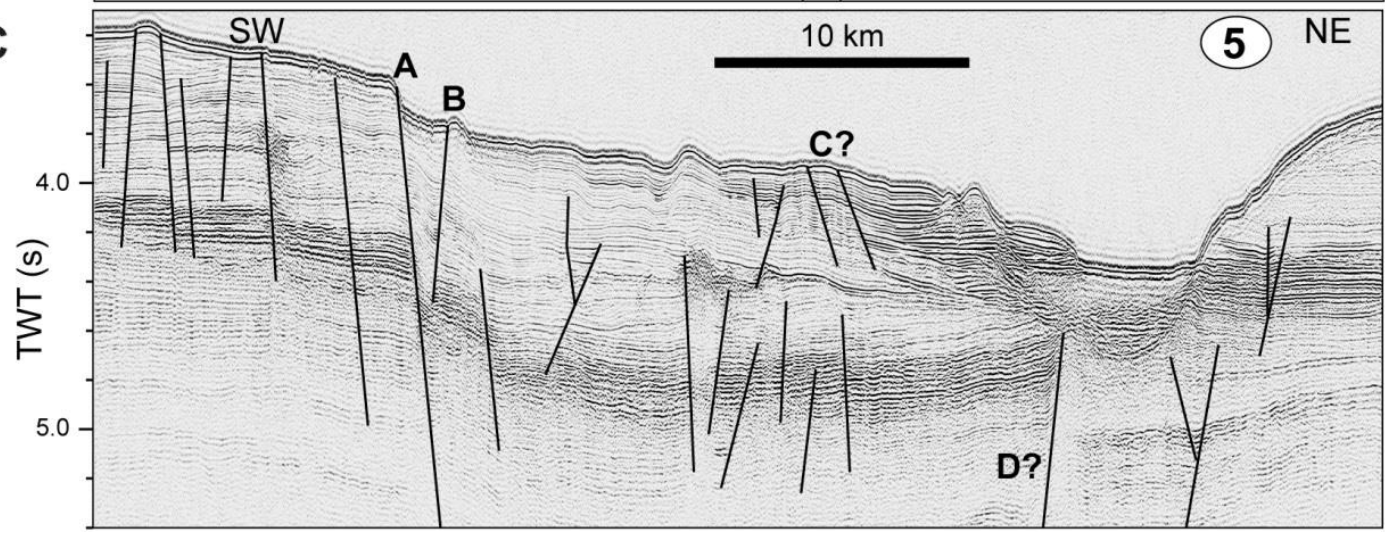

Figure 16 ( 2 columns) 
A

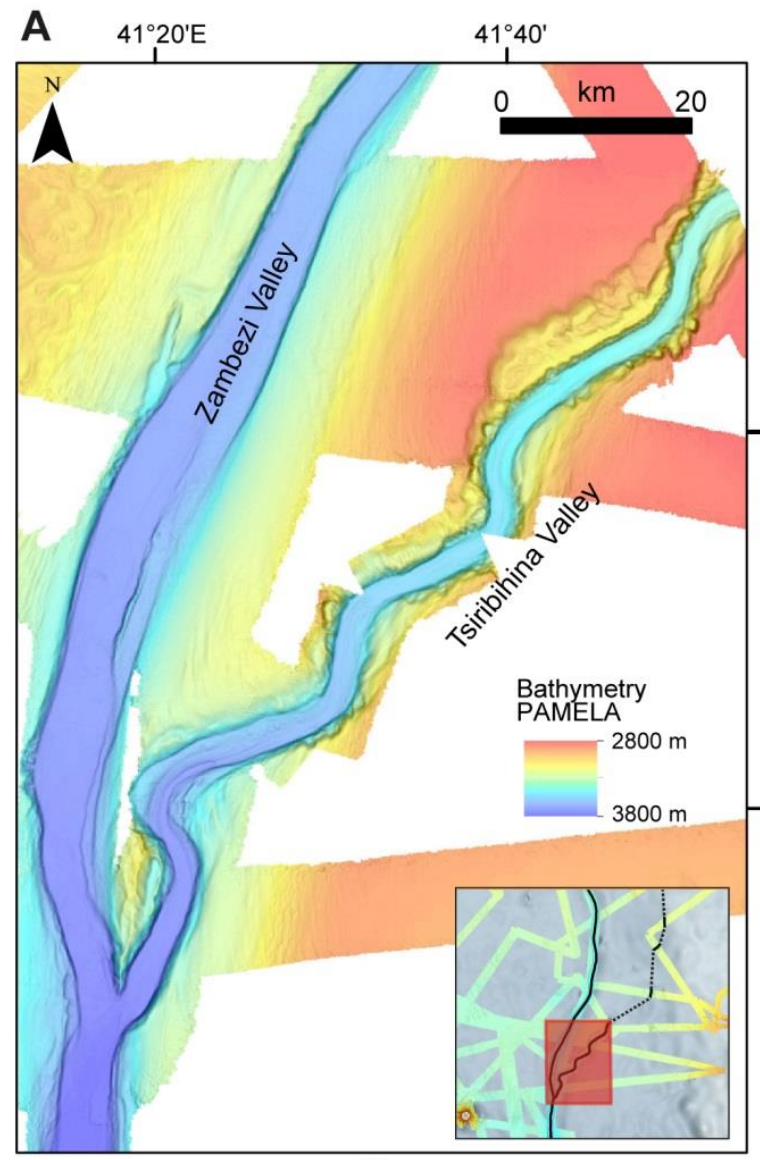

B
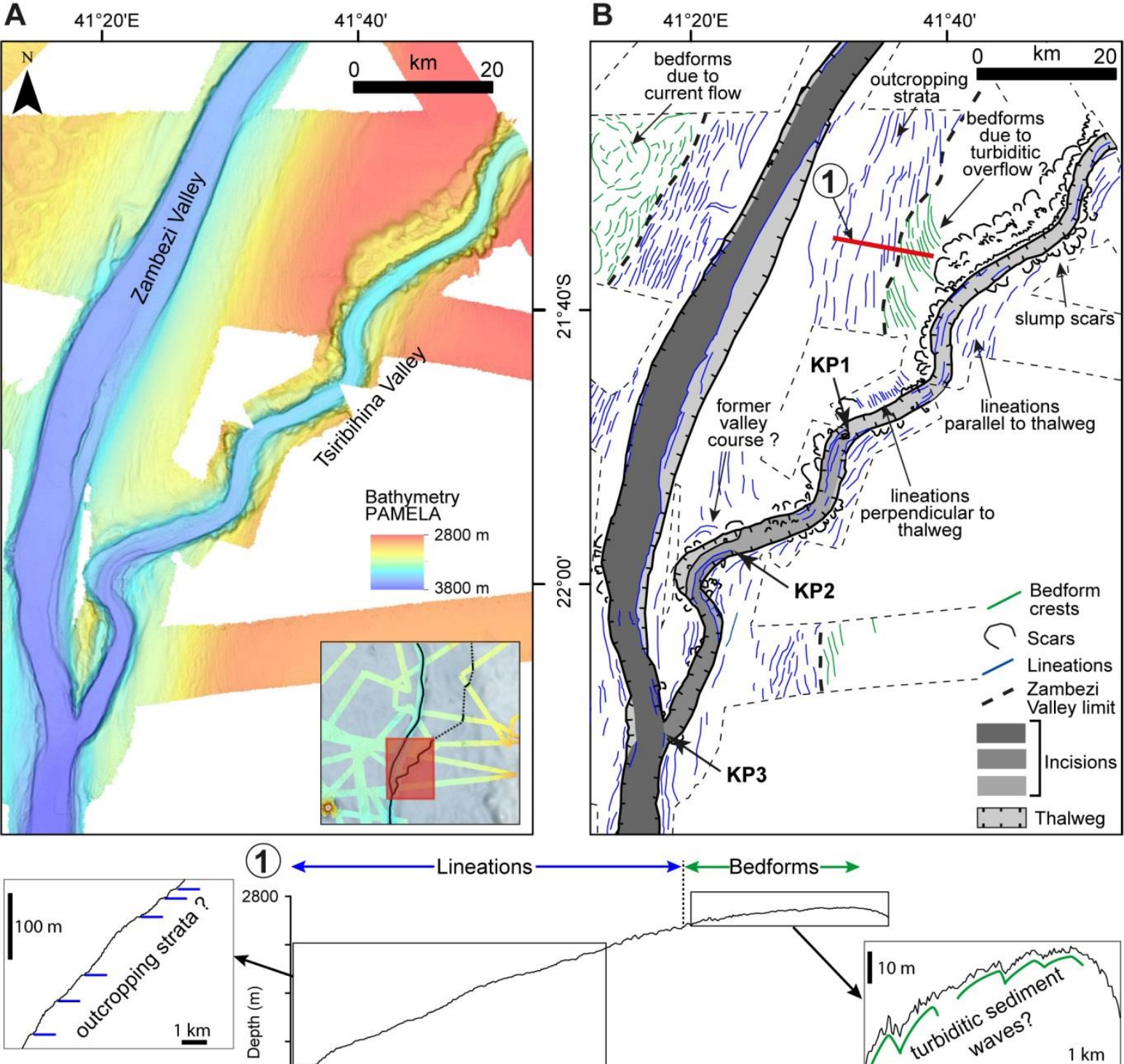

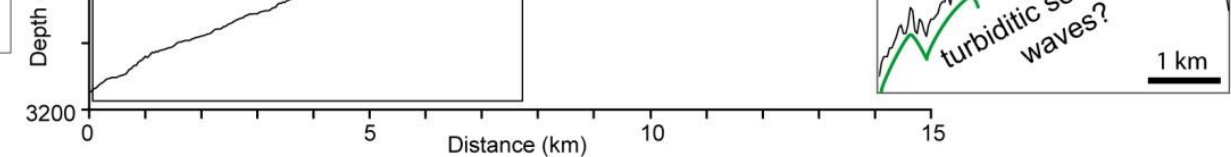

Figure 17 ( 2 columns) 
Hemipelagic/contouritic ren

Turbiditic/Zambezi Fan

Valley

Turbidity current overflow or channel-levees Distal depositional lobes and schematized erosional channels Contour current bedforms $\lceil$ Sediment waves

Hummocky seafloor

Opaque of unknown origin
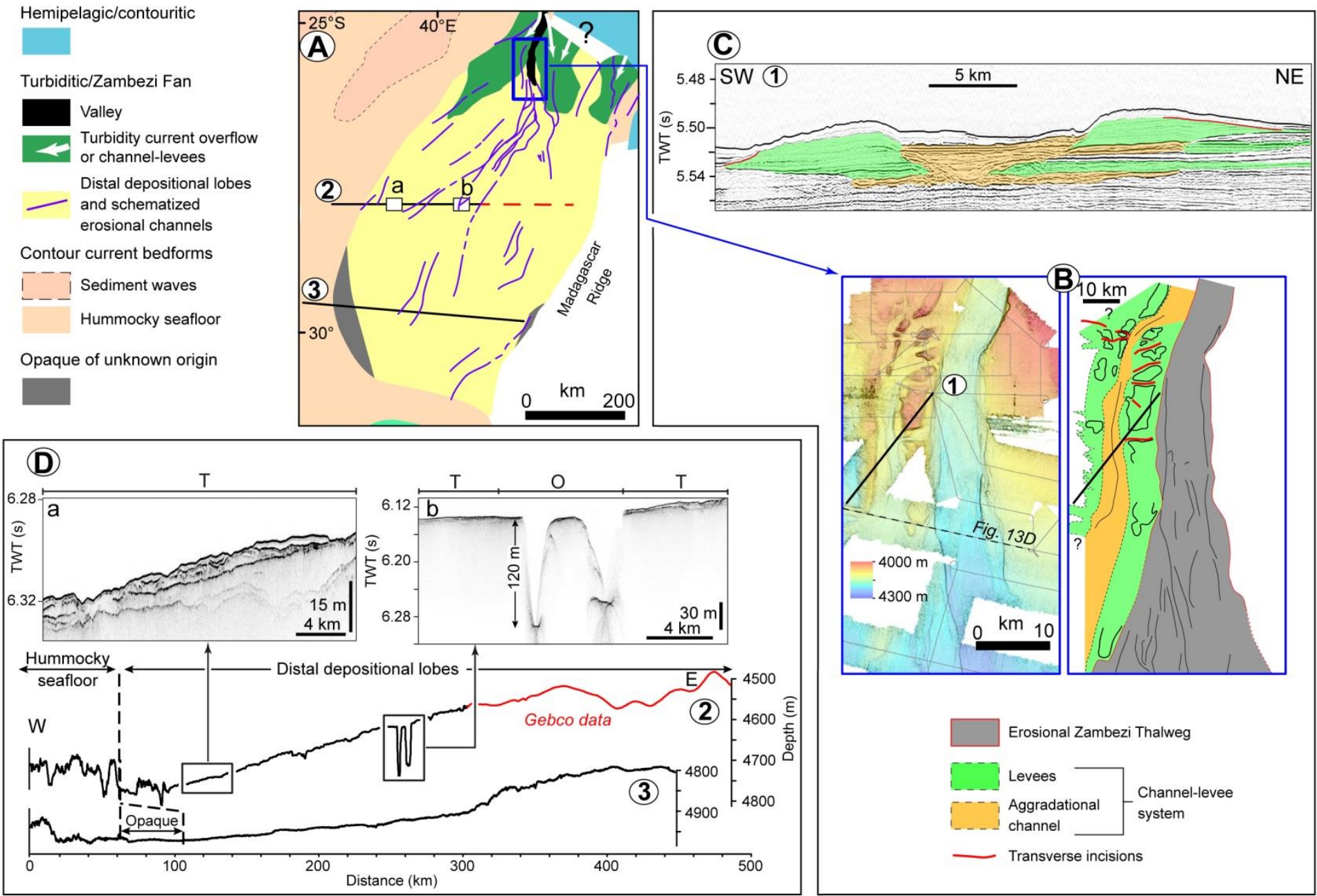

Figure 18 ( 2 columns) 

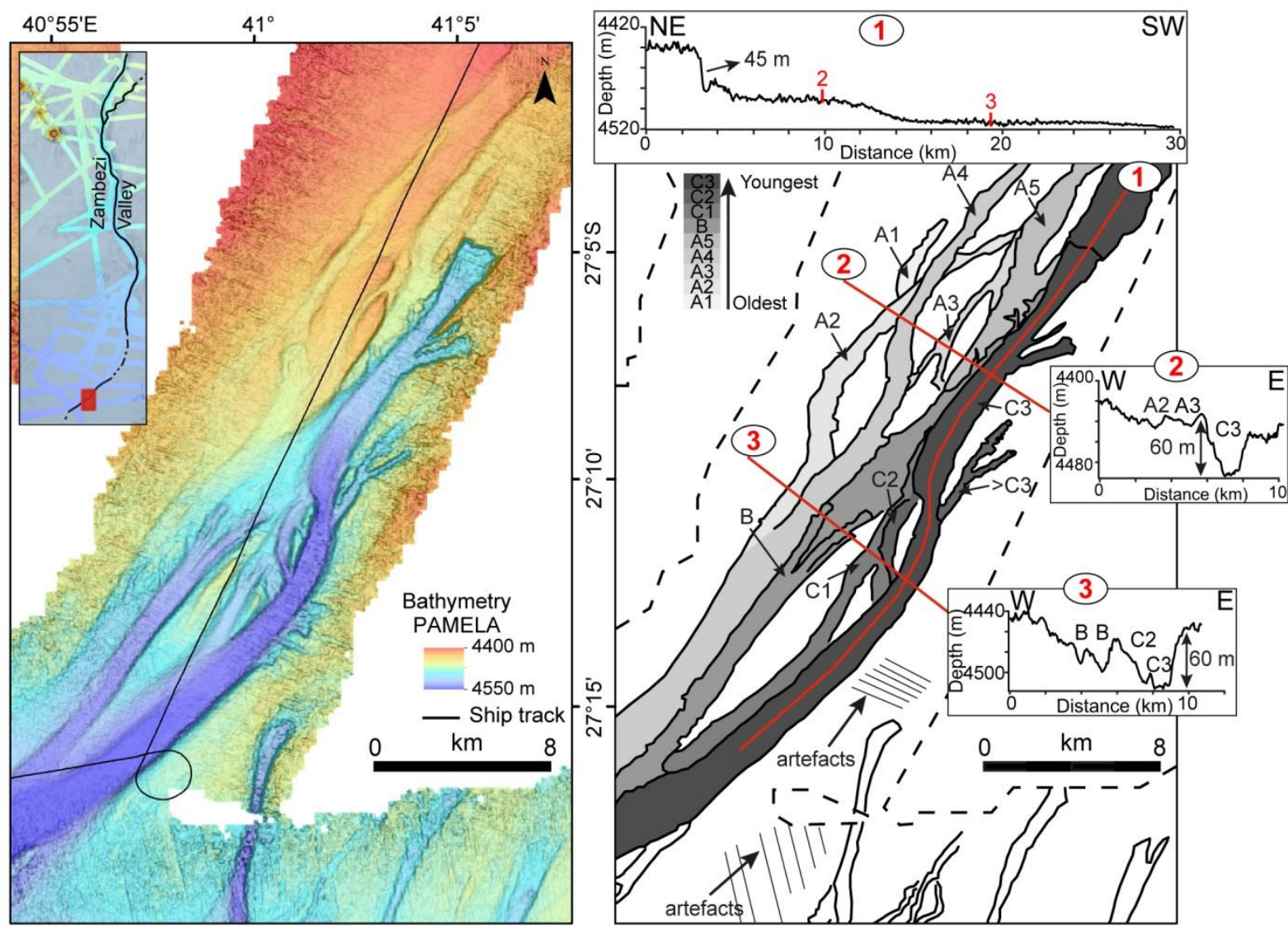

Figure 19 ( 2 columns) 


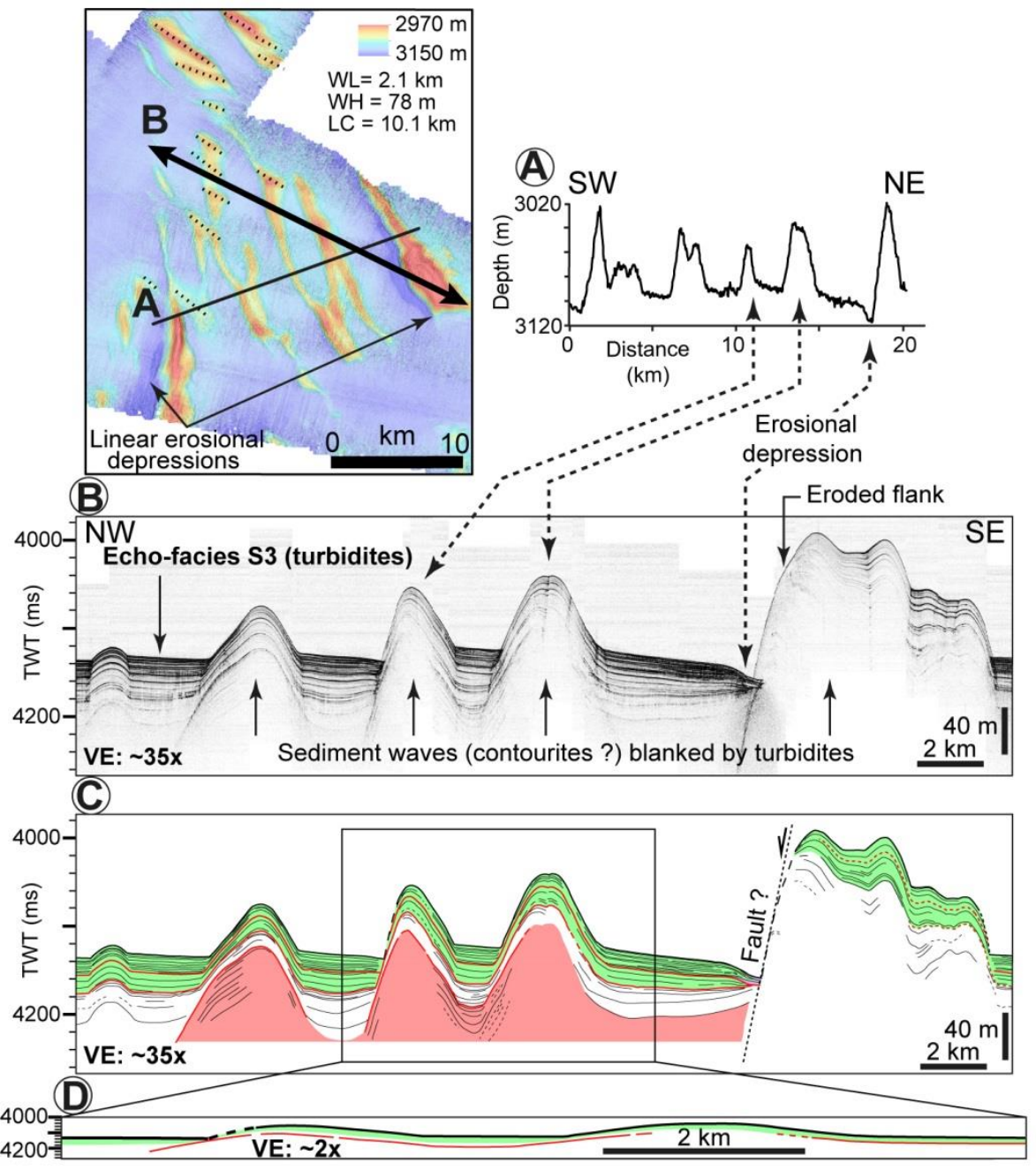

Figure 20 ( 1.5 column) 

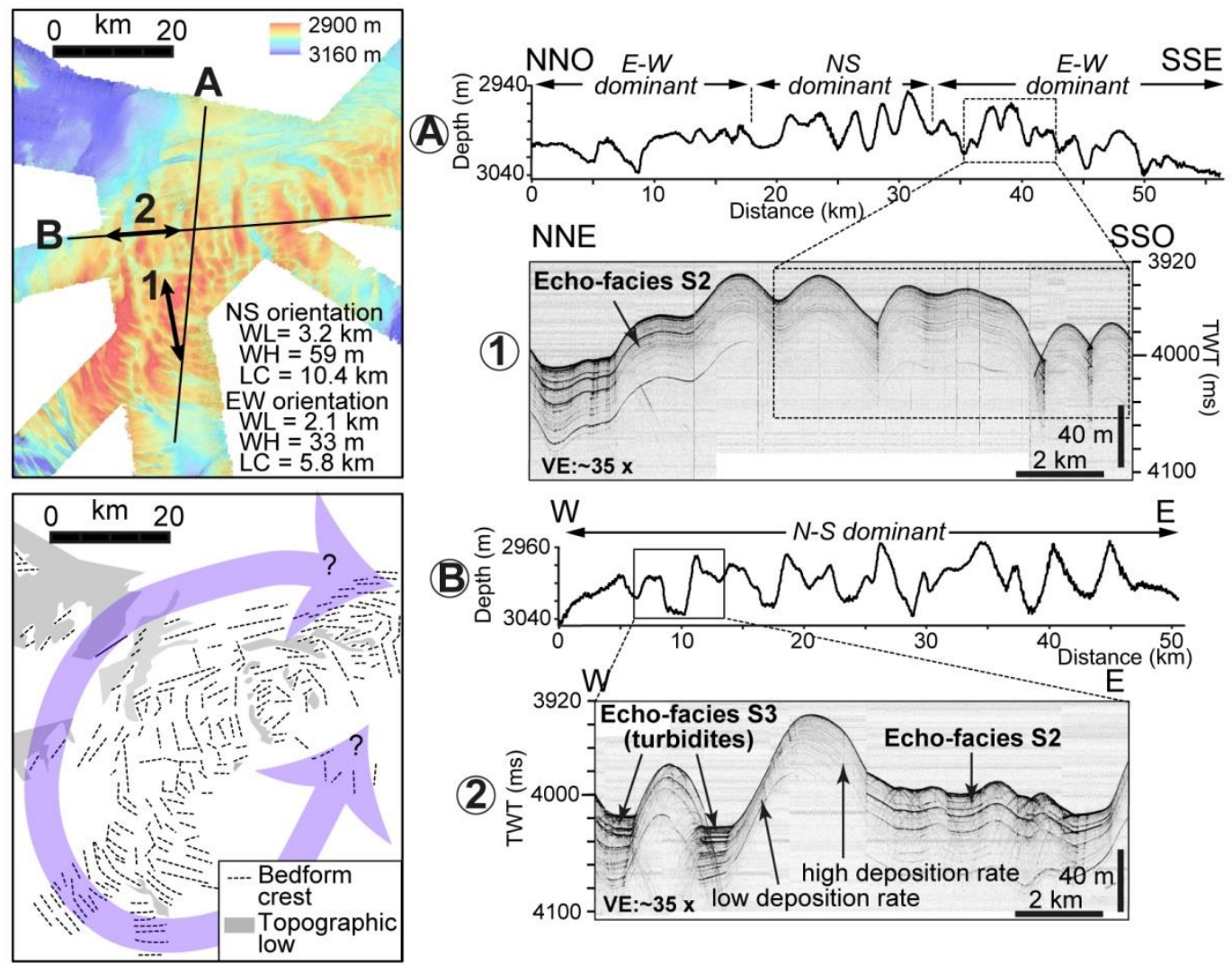

Figure 21 (1.5 column) 

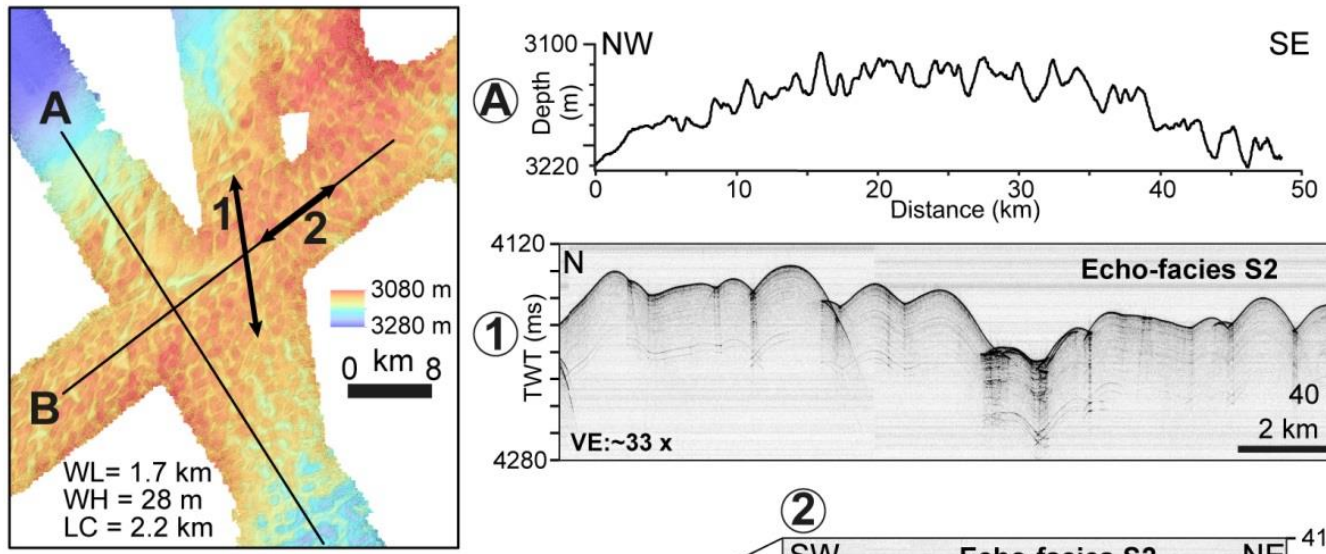

SE

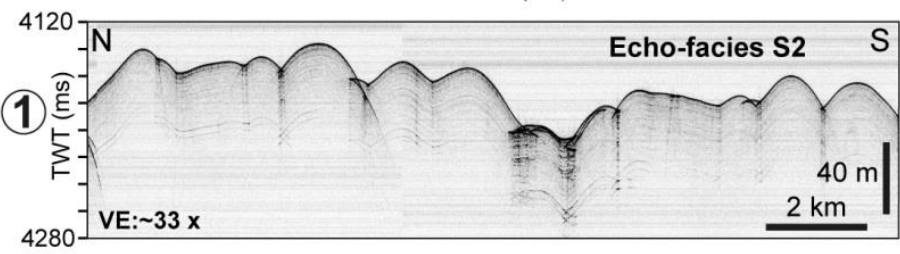

$\mathrm{LC}=2.2 \mathrm{~km}$

(2)

(B)

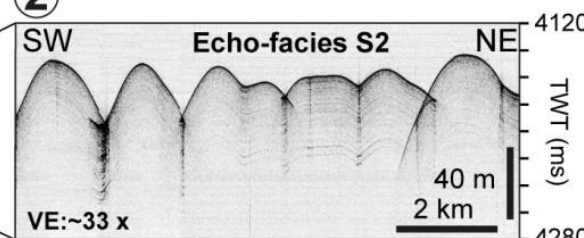

Figure 22 (1.5 column) 

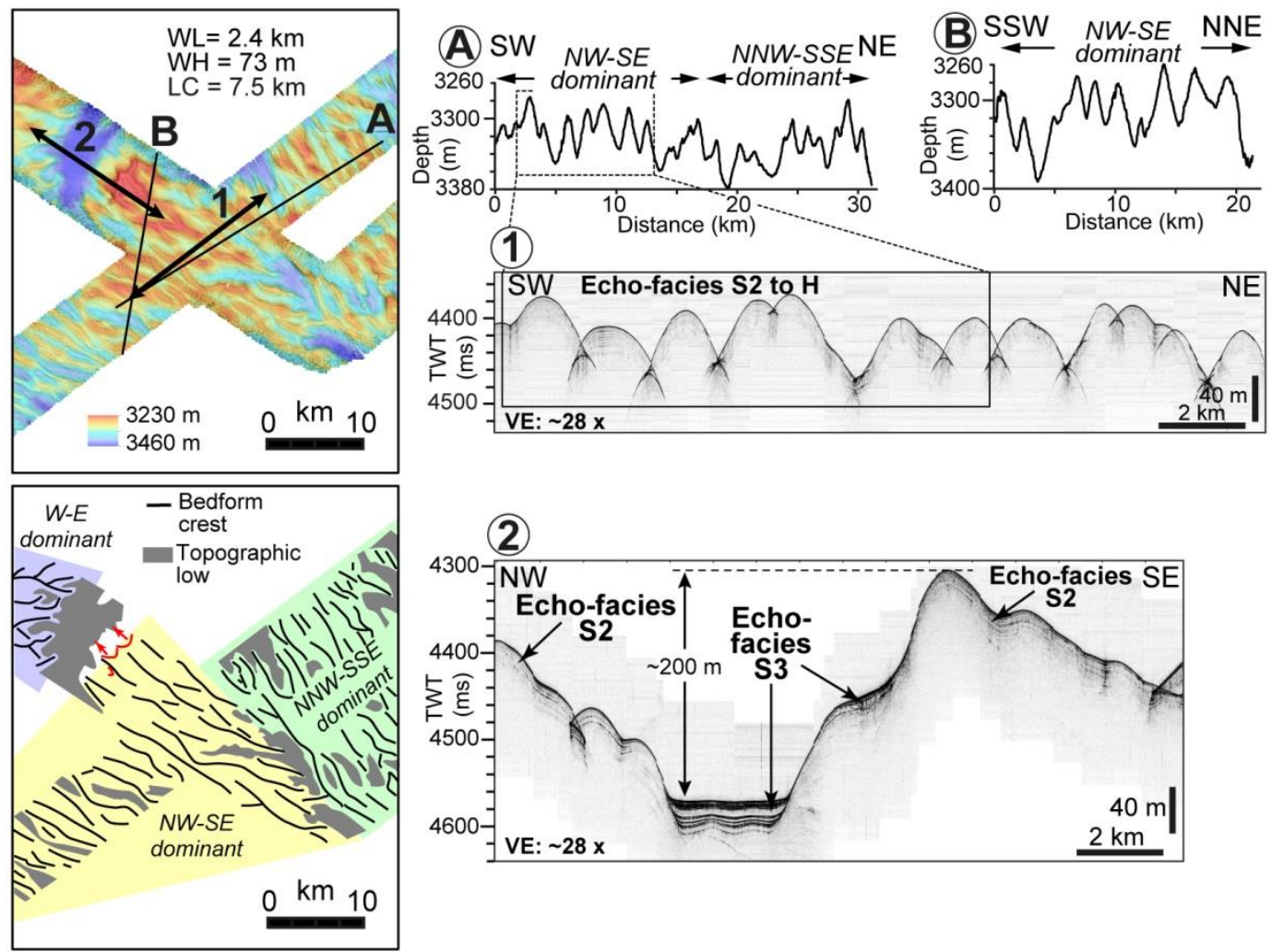

Figure 23 ( 1.5 column) 


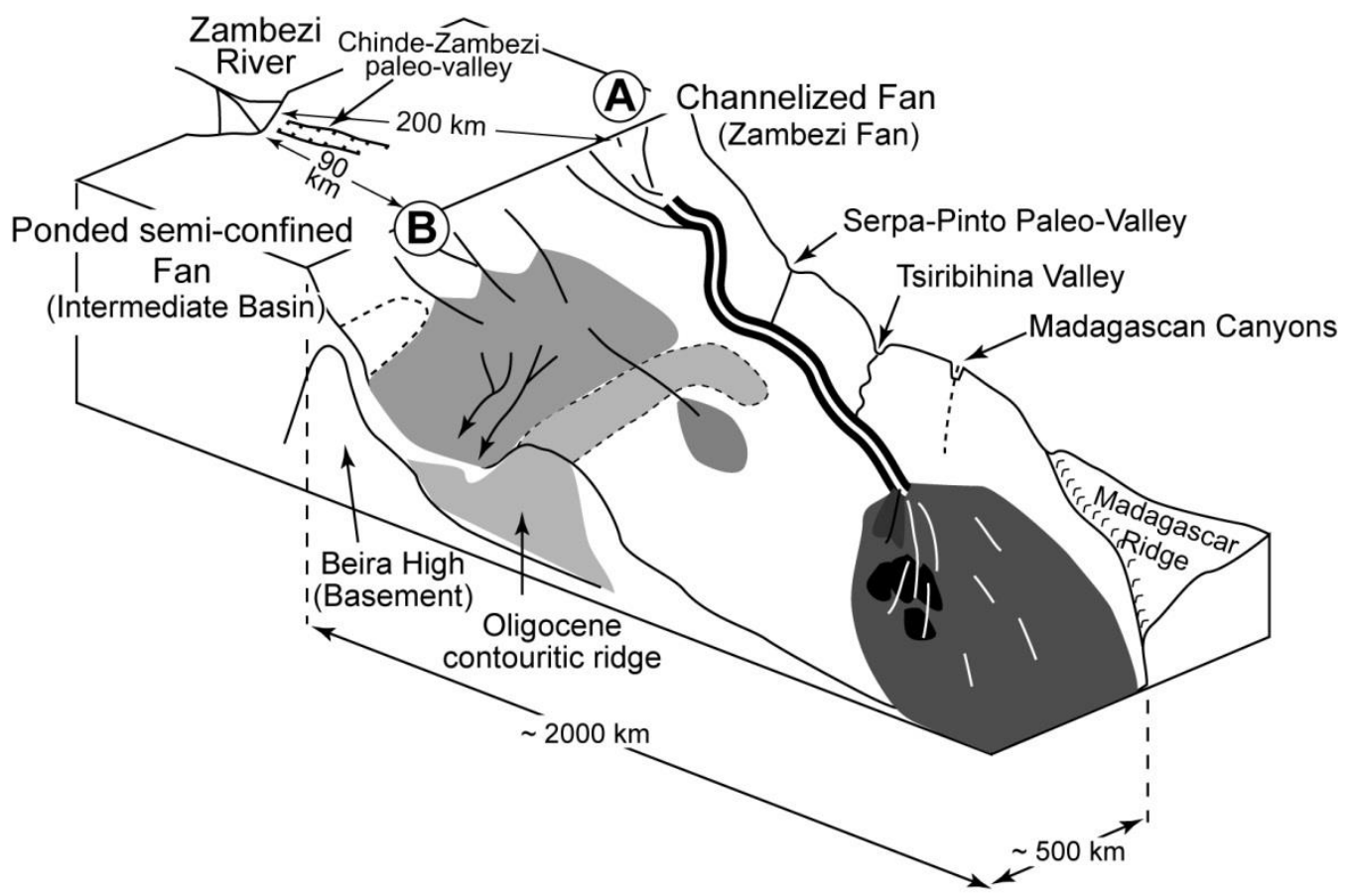

Figure 24 ( 1.5 column) 
A
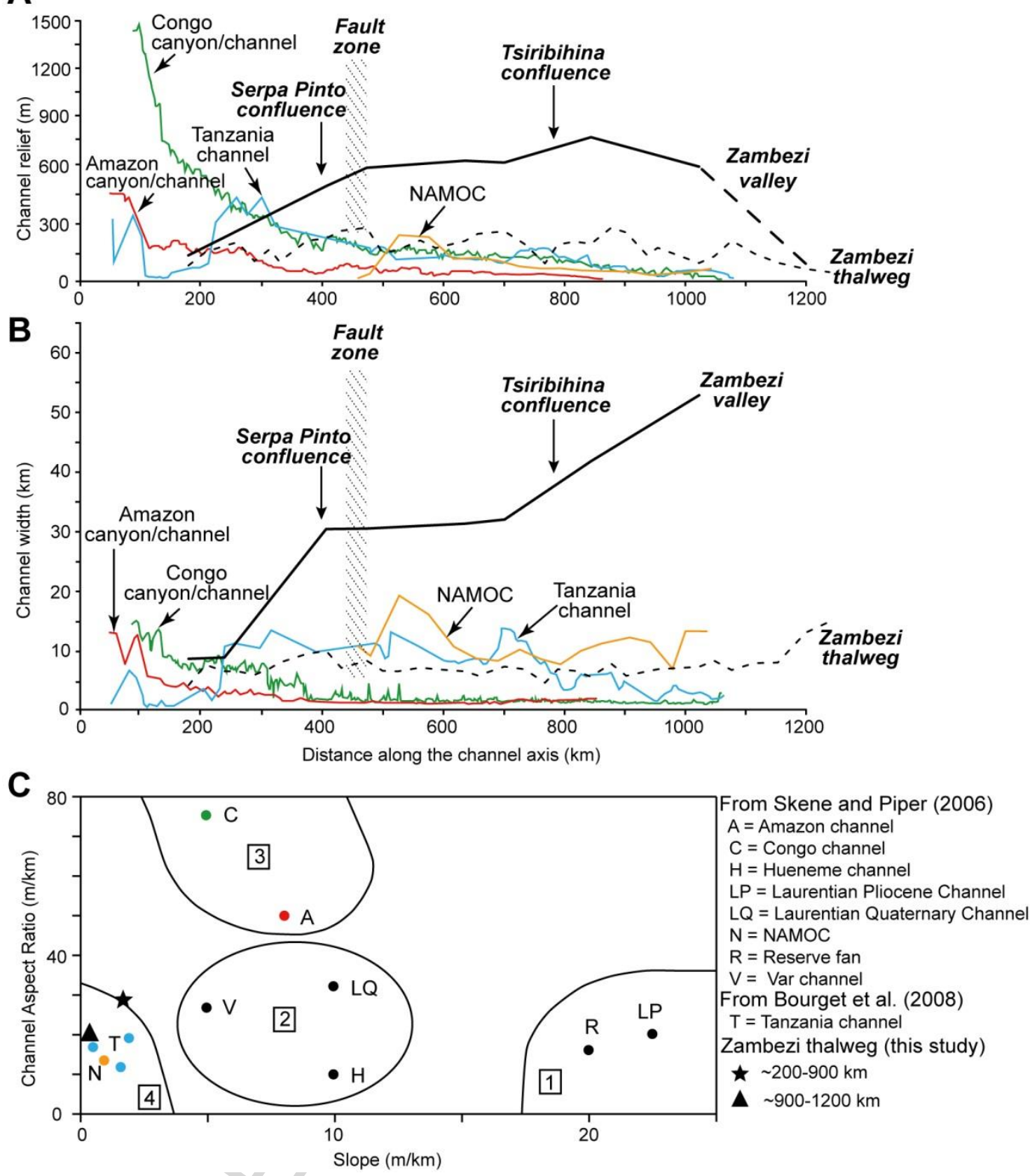

Figure 25 ( 1.5 column) 

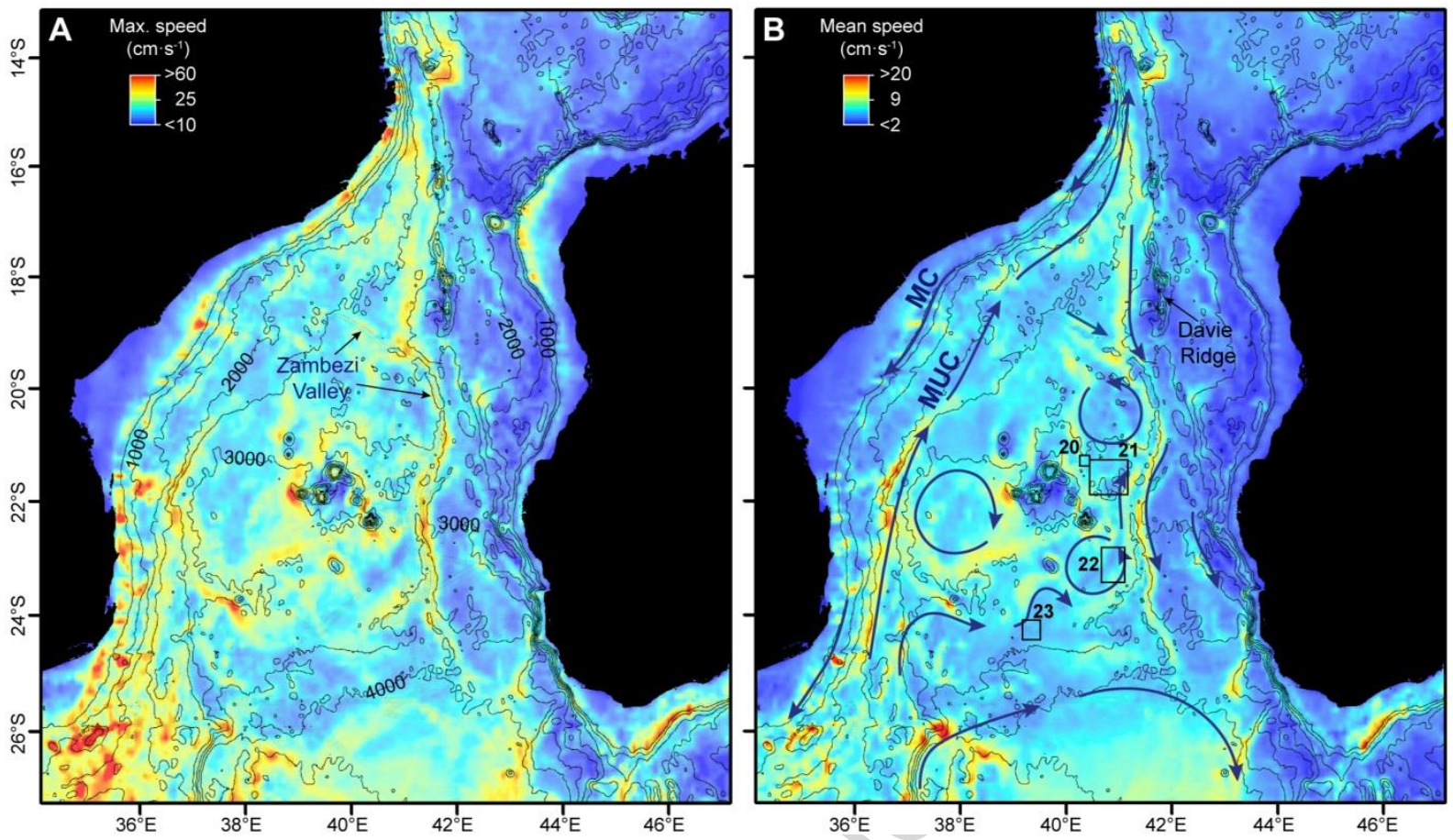

Figure 26 ( 2 columns) 


\begin{tabular}{|c|c|c|c|c|}
\hline \multirow[b]{2}{*}{ PAMELA Cruises } & \multicolumn{2}{|c|}{ Bathymetric and SBP data } & \multicolumn{2}{|c|}{ Multibeam acquisition system } \\
\hline & $\begin{array}{l}\text { Acquisition } \\
\text { speed } \\
\text { (kts) }\end{array}$ & $\begin{array}{l}\text { Profile } \\
\text { distance } \\
(\mathrm{km})\end{array}$ & Type & $\begin{array}{c}\text { Emission frequency } \\
(\mathrm{kHz})\end{array}$ \\
\hline PTOLEMEE $^{1}$ & $8-10$ & 6910 & Kongsberg EM122 & 12 \\
\hline PAMELA-MOZ1 $^{2}$ & $8-10$ & 3350 & Kongsberg EM122 & 12 \\
\hline PAMELA-MOZ2 $^{3}$ & $8-10$ & 12020 & Kongsberg EM122 & 12 \\
\hline PAMELA-MOZ4 ${ }^{4}$ & $8-10$ & 10470 & Reson Seabat 7150 & 12 \\
\hline
\end{tabular}

${ }^{1}$ : Jorry, 2014, ${ }^{2}$ : Olu, 2014, ${ }^{3}$ : Robin and Droz, 2014, ${ }^{4}$ : Jouet and Deville, 2015

Table 1 


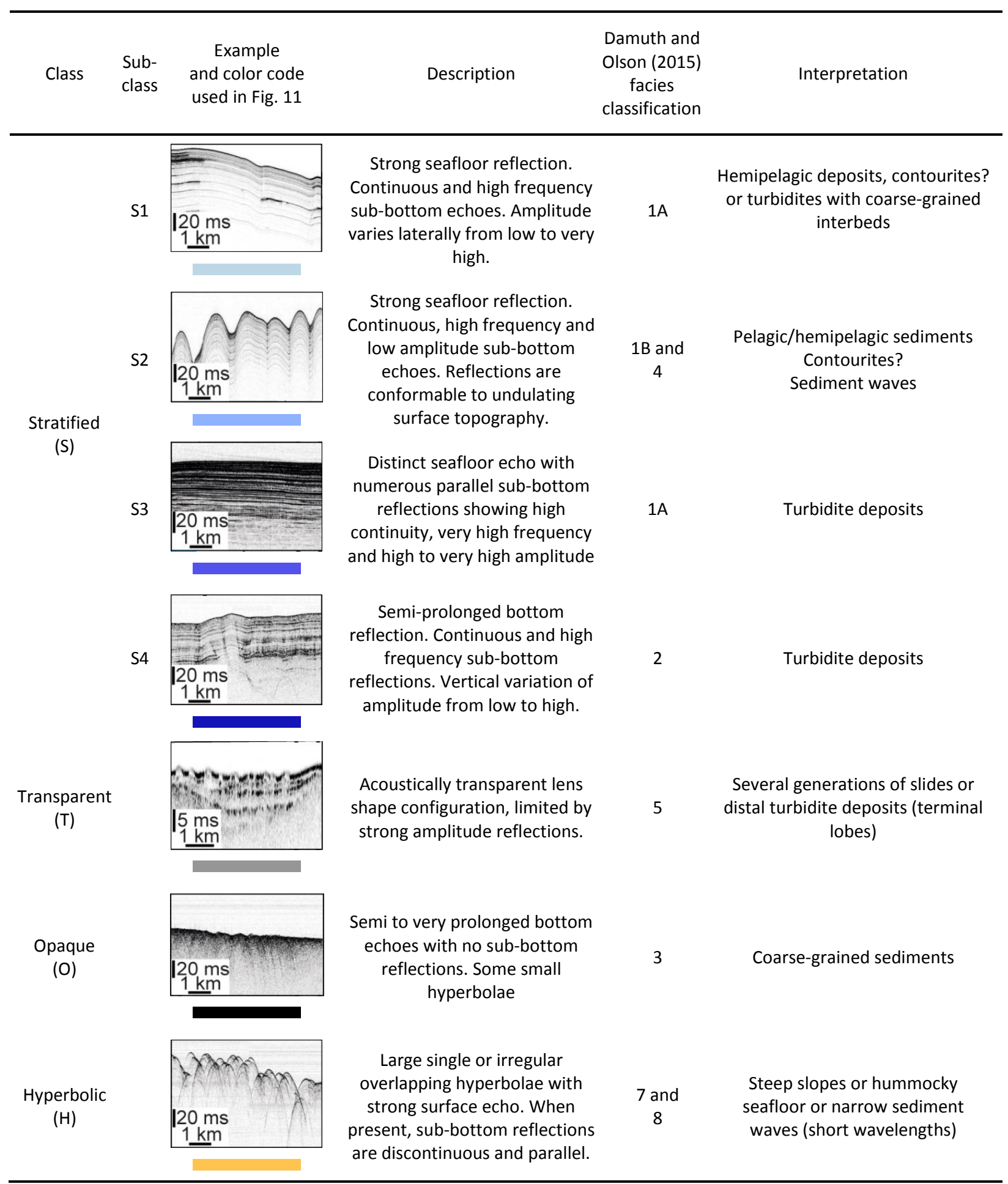

Table 2 


\section{References}

Adeogba, A. A., McHargue, T. R., Graham, S. A., 2005. Transient fan architecture and depositional controls from near-surface 3-D seismic data, Niger Delta continental slope. AAPG bulletin 89(5), 627-643. https://doi.org/10.1306/11200404025

Antobreh, A. A., Krastel, S., 2006. Morphology, seismic characteristics and development of Cap Timiris Canyon, offshore Mauritania: a newly discovered canyon preserved-off a major arid climatic region. Marine and Petroleum Geology 23, 37-59. https://doi.org/10.1016/j.marpetgeo.2005.06.003

Babonneau, N., Cattaneo, A., Savoye, B., Barjavel, G., Déverchère, J., Yelles, K., 2012. The Kramis deep-sea fan off western Algeria: Role of sediment waves in turbiditic levee growth. SEPM Special Publication 99. Application of the Principles of Seismic Geomorphology to ContinentalSlope and Base-of-Slope Systems: Case Studies from Seafloor and Near-Seafloor Analogues. 293-308.

Babonneau, N., Savoye, B., Cremer, M., Klein, B., 2002. Morphology and architecture of the present canyon and channel system of the Zaire deep-sea fan. Marine and Petroleum Geology 19, 445467. https://doi.org/10.1016/S0264-8172(02)00009-0

Baby, G., 2017. Mouvements verticaux des marges passives d'Afrique australe depuis $130 \mathrm{Ma}$, étude couplée: stratigraphie de bassin: analyse des formes du relief. Ph.D. Thesis, Université de Rennes 1. France. 363 pp.

Beiersdorf, H., Kudrass, H. R., Von Stackelberg, U., 1980. Placer Deposits of limenite and Zircon on the Zambezi Shelf. Geologisches Jahrbuch Reihe D 36,1-85. 
Biscara, L., 2011. Le système turbiditique de l'Ogooué (Gabon, Marge Ouest Africaine): Évolution Fini-Holocène de la morphologie et de la dynamique sédimentaire. Ph.D. Thesis, Université Bordeaux I. France. 316 pp.

Bourget, J., Zaragosi, S., Garlan, T., Gabelotaud, I., Guyomard, P., Dennielou, B., Ellouz-Zimmermann, N., Schneider, J., 2008. Discovery of a giant deep-sea valley in the Indian Ocean, off eastern Africa: The Tanzania channel. Marine Geology 255, 179-185. https://doi.org/10.1016/j.margeo.2008.09.002

Bourget, J., Zaragosi, S., Ellouz-Zimmermann, N., Mouchot, N., Garlan, T., Schneider, J., Lanfumey, V., Lallemant, S., 2011. Turbidite system architecture and sedimentary processes along topographically complex slopes: the Makran convergent margin. Sedimentology 58, 376-406. https://doi.org/10.1111/j.1365-3091.2010.01168.x

Bourillet, J. F., Ferry, J. N., Bourges, P., 2013. PAMELA "PASSIVE MARGINS EXPLORATION LABORATORIES", http://dx.doi.org/10.18142/236

Breitzke, M., Wiles, E., Krocker, R., Watkeys, M. K., Jokat, W., 2017. Seafloor morphology in the Mozambique Channel: evidence for long-term persistent bottom-current flow and deepreaching eddy activity. Marine Geophysical Research 38, 241-269. https://doi.org/10.1007/s11001-017-9322-7

Cattaneo, A., Riboulot, V., Jouet, G., Lempreur, C., Scalabrin, C., Marsett, T., Le Roy, P., Droz, L., Deville, E., Cauquil, E., 2017. Submarine landslides impact on the morphology of the Mozambique continental margin. In: IMS 2017-International Meeting of Sedimentology, Toulouse (France), $161 \mathrm{pp}$.

Courgeon, S., Jorry, S. J., Camoin, G., BouDagher-Fadel, M., Jouet, G., Révillon, S., Bachèlery, P., Pelleter, E., Borgomano, J., Poli, E., 2016. Growth and demise of Cenozoic isolated carbonate 
platforms: New insights from the Mozambique Channel seamounts (SW Indian Ocean). Marine Geology 380, 90-105. https://doi.org/10.1016/j.margeo.2016.07.006

Courgeon, S., Jorry, S. J., Jouet, G., Camoin, G., BouDagher-Fadel, M. K., Bachèlery, P., Caline, B., Boichard, R., Révillon, S., Thomas, Y., Thereau, E. and Thereau, E., 2017. Impact of tectonic and volcanism on the Neogene evolution of isolated carbonate platforms (SW Indian Ocean). Sedimentary Geology 355, 114-131. https://doi.org/10.1016/j.sedgeo.2017.04.008

Covault, J. A., Graham, S. A., 2010. Submarine fans at all sea-level stands: Tectono-morphologic and climatic controls on terrigenous sediment delivery to the deep sea. Geology 38, 939-942. https://doi.org/https://doi.org/10.1130/G31081.1

Cunningham, A. P., Barker, P. F., 1996. Evidence for westward-flowing Weddell Sea deep water in the Falkland Trough, western South Atlantic. Deep Sea Research Part I: Oceanographic Research Papers 43, 643-654. https://doi.org/https://doi.org/10.1016/0967-0637(96)00034-9

Curray, J. R., Emmel, F. J., Moore, D.G., 2003. The Bengal Fan: morphology, geometry, stratigraphy, history and processes. Marine and Petroleum Geology 19, 1191-1223. https://doi.org/10.1016/S0264-8172(03)00035-7

Damuth, J. E., 1980. Quaternary sedimentation processes in the South China Basin as revealed by echo-character mapping and piston-core studies. The tectonic and geologic evolution of southeast Asian seas and islands - Geophysical Monograph 23, 105-125. https://doi.org/10.1029/GM023p0105

Damuth, J. E., Flood, R. D., 1985. Amazon Fan, Atlantic Ocean, in: Bouma A.H., Normark W.R., Barnes N.E. (eds) Submarine Fans and Related Turbidite Systems. Springer, New York, NY, pp. 97-106. https://doi.org/10.1007/978-1-4612-5114-9_15 
Damuth, J. E., Olson, H. C., 2015. Latest Quaternary sedimentation in the northern Gulf of Mexico Intraslope Basin Province: I. Sediment facies and depositional processes. Geosphere 11, 16891718. https://doi.org/10.1130/GES01090.1

Davies, T. A., Luyendyk, B. P., Rodolfo, K. S., Kempe, D. R. C. , McKelvey, B. C., Leidy, R. D., Horvath, G. J., Hyndman, R. D., Thierstein, H. R., Herb, R. C., Boltovskoy, E., Doyle, P.,1974. 9. Site 250, leg 26, Deep Sea Drilling Project. doi:10.2973/dsdp.proc.26.103.1974

Deptuck, M. E., Steffens, G. S., Barton, M., Pirmez, C., 2003. Architecture and evolution of upper fan channel-belts on the Niger Delta slope and in the Arabian Sea. Marine and Petroleum Geology 20, 649-676. https://doi.org/10.1016/j.marpetgeo.2003.01.004

De Ruijter, W. P. M., Ridderinkhof, H., Lutjeharms, J. R. E., Schouten, M. W., Veth, C., 2002. Observations of the flow in the Mozambique Channel. Geophysical Research Letters 29, 140-1140-3. https://doi.org/10.1029/2001GL013714

Deville, E., Marsset, T., Courgeon, S., Jatiault, R., Ponte, J. P., Thereau, E., Jouet, G., Jorry, S. J., Droz, L., 2018. Active fault system across the oceanic lithosphere of the Mozambique Channel: Implications for the Nubia-Somalia southern plate boundary. Earth and Planetary Science Letters 502, 210-220. https://doi.org/https://doi.org/10.1016/j.epsl.2018.08.052

Dietrich, W. E., Smith, J. D., 1984. Bed load transport in a river meander. Water Resources Research 20, 1355-1380. https://doi.org/10.1029/WR020i010p01355

Dietrich, W. E., Smith, J. D., Dunne, T. 1979. Flow and sediment transport in a sand bedded meander. The Journal of Geology 87(3), 305-315. https://doi.org/10.1086/628419

Donohue, K. A., Toole, J. M., 2003. A near-synoptic survey of the Southwest Indian Ocean. Deep Sea Research Part II: Topical Studies in Oceanography 50, 1893-1931. https://doi.org/10.1016/S0967-0645(03)00039-0 
Droz, L., Mougenot, D., 1987. Mozambique upper fan: origin of depositional units. AAPG Bulletin 71, $1355-1365$.

Droz, L., Rigaut, F., Cochonat, P., Tofani, R., 1996. Morphology and recent evolution of the Zaire turbidite system (Gulf of Guinea). Geological Society of America Bulletin 108, 253-269. DOI:10.1130/0016-7606(1996)108<0253:MAREOT>2.3.CO;2

Ducassou, E., Capotondi, L., Murat, A., Bernasconi, S. M., Mulder, T., Gonthier, E., Migeon, S., Duprat, J., Giraudeau, J., Mascle, J., 2007. Multiproxy Late Quaternary stratigraphy of the Nile deep-sea turbidite system - Towards a chronology of deep-sea terrigeneous systems. Sedimentary Geology 200, 1-13. https://doi.org/10.1016/j.sedgeo.2007.01.023

Ercilla, G., Alonso, B., Estrada, F., Chiocci, F. L., Baraza, J., Farran, M., 2002. The Magdalena Turbidite System (Caribbean Sea): present-day morphology and architecture model. Marine Geology 185, 303-318. https://doi.org/10.1016/S0025-3227(02)00182-2

Fischer, M. D., Uenzelmann-Neben, G., Jacques, G., Werner, R., 2016. The Mozambique Ridge: a document of massive multi-stage magmatism. Geophysical Journal International 208, 449-467. https://doi.org/10.1093/gji/ggw403

Flood, R. D., Piper, D. J. W., Klaus, A., \& Peterson, L. C. (Eds.), 1997. Amazon Fan sedimentation: the relationship to equatorial climate change, continental denudation, and sea-level fluctuations. In: Proceedings of the Ocean Drilling Program, Scientific Results, 155, College Station, TX, pp. 653675.

Flood, R. D., Shor, A. N., 1988. Mud waves in the Argentine Basin and their relationship to regional bottom circulation patterns. Deep Sea Research Part A. Oceanographic Research Papers 35, 943-971. https://doi.org/10.1016/0198-0149(88)90070-2 
Forwick, M., Laberg, J. S., Hass, H. C., Osti, G., 2015. The Kongsfjorden Channel System offshore NW Svalbard: downslope sedimentary processes in a contour-current-dominated setting. Arktos 1 , 1-16. https://doi.org/10.1007/s41063-015-0018-4

Fournier, L., 2016. Rôle des facteurs de contrôle sur l'architecture et le fonctionnement sédimentaire des systèmes turbiditiques de l'océan Indien au cours du Cénozoïque : exemple des systèmes Rovuma-Rufiji et Gange-Brahmapoutre. Sciences de la Terre. Ph.D. Thesis, Université de Bordeaux. France. 306 pp.

Gamberi, F., Rovere, M., 2011. Architecture of a modern transient slope fan (Villafranca fan, Gioia basin-Southeastern Tyrrhenian Sea). Sedimentary Geology 236, 211-225. https://doi.org/10.1016/j.sedgeo.2011.01.007

GEBCO, 2014. GEBCO_2014 Grid. British Oceanographic Data Centre (BODC). Available at: http://www.gebco.net/data_and_products/gridded_bathymetry_data/.

Hall, I. R., Hemming, S. R., LeVay, L. J., Barker, S. R., Berke, M. A., Brentegani, L., Caley, T., CartagenaSierra, A., Charles, C. D., Coenen, J. J., 2016. International Ocean Discovery Program; Expedition 361 preliminary report; South African climates (Agulhas LGM density profile); 30 January-31 March 2016. https://doi.org/10.14379/iodp.pr.361.2016

Halo, I., Backeberg, B., Penven, P., Ansorge, I., Reason, C., Ullgren, J. E., 2014. Eddy properties in the Mozambique Channel: A comparison between observations and two numerical ocean circulation models. Deep Sea Research Part II: Topical Studies in Oceanography 100, 38-53. https://doi.org/10.1016/j.dsr2.2013.10.015

Hesse, R., Chough, S. K., Rakofsky, A., 1987. The Northwest Atlantic mid-ocean channel of the Labrador Sea. V. Sedimentology of a giant deep-sea channel. Canadian Journal of Earth Sciences 24, 1595-1624. https://doi.org/10.1139/e87-155 
Hinderer, M., 2012. From gullies to mountain belts: A review of sediment budgets at various scales. Sedimentary Geology 280, 21-59. https://doi.org/10.1016/j.sedgeo.2012.03.009

Hsiung, K. H., Yu, H. S., Chiang, C. S., 2018. The modern Kaoping transient fan offshore SW Taiwan: Morphotectonics and development. Geomorphology 300, 151-163. https://doi.org/10.1016/j.geomorph.2017.10.013

Hustoft, S., Bünz, S., Mienert, J., Chand, S., 2009. Gas hydrate reservoir and active methane-venting province in sediments on< 20 Ma young oceanic crust in the Fram Strait, offshore NW-Svalbard. Earth and Planetary Science Letters 284, 12-24. https://doi.org/10.1016/j.epsl.2009.03.038

Jorry, S. J., 2014. PTOLEMEE cruise, RV L'Atalante, http://dx.doi.org/10.17600/14000900

Jorry, S. J., Camoin, G. F., Jouet, G., Le Roy, P., Vella, C., Courgeon, S., Prat, S., Fontanier, C., Paumard, V., Boulle, J. 2016. Modern sediments and Pleistocene reefs from isolated carbonate platforms (Iles Eparses, SW Indian Ocean): A preliminary study. Acta Oecologica 72, 129-143. https://doi.org/10.1016/j.actao.2015.10.014

Jouet, G., Deville, E., 2015. PAMELA-MOZ04 cruise, RV Pourquoi Pas ?, http://dx.doi.org/10.17600/15000700

Klaucke, I., Masson, D. G., Kenyon, N. H., Gardner, J. V., 2004. Sedimentary processes of the lower Monterey Fan channel and channel-mouth lobe. Marine Geology 206, 181-198. https://doi.org/10.1016/j.margeo.2004.02.006

Kolla, V., Kostecki, J. A., Henderson, L., Hess, L., 1980a. Morphology and Quaternary sedimentation of the Mozambique Fan and environs, southwestern Indian Oceans. Sedimentology 27, 357-378. https://doi.org/10.1111/j.1365-3091.1980.tb01188.x 
Kolla, V., Eittreim, S., Sullivan, L., Kostecki, J. A., Burckle, L. H., 1980b. Current-controlled, abyssal microtopography and sedimentation in Mozambique Basin, southwest Indian Ocean. Marine Geology 34, 171-206. https://doi.org/10.1016/0025-3227(80)90071-7

Kuenen, P. H., Migliorini, C., 1950. Turbidity currents as a cause of graded bedding. The Journal of Geology 58, 91-127. https://doi.org/10.1086/625710

Leinweber, V. T., Jokat, W., 2011. Is there continental crust underneath the northern Natal Valley and the Mozambique Coastal Plains? Geophysical Research Letters 38(14), 1-7. https://doi.org/10.1029/2011GL047659

Leinweber, V. T., Jokat, W., 2012. The Jurassic history of the Africa-Antarctica corridor-new constraints from magnetic data on the conjugate continental margins. Tectonophysics 530, 87101. https://doi.org/10.1016/j.tecto.2011.11.008

Lonsdale, P., Malfait, B., 1974. Abyssal dunes of foraminiferal sand on the Carnegie Ridge. Geological Society of America Bulletin 85, 1697-1712. https://doi.org/10.1130/00167606(1974)85<1697:ADOFSO>2.0.CO;2

Madof, A. S., Christie-Blick, N., Anders, M. H., 2009. Stratigraphic controls on a salt-withdrawal intraslope minibasin, north-central Green Canyon, Gulf of Mexico: Implications for misinterpreting sea level change. AAPG bulletin 93, 535-561. https://doi.org/10.1306/12220808082

Mahanjane, E. S., 2012. A geotectonic history of the northern Mozambique Basin including the Beira High - A contribution for the understanding of its development. Marine and Petroleum Geology 36, 1-12. https://doi.org/10.1016/j.marpetgeo.2012.05.007 
Mahanjane, E. S., 2014. The Davie Fracture Zone and adjacent basins in the offshore Mozambique Margin - A new insights for the hydrocarbon potential. Marine and Petroleum Geology 57, 561571. https://doi.org/10.1016/j.marpetgeo.2014.06.015

Marchès, E., Mulder, T., Cremer, M., Bonnel, C., Hanquiez, V., Gonthier, E., Lecroart, P., 2007. Contourite drift construction influenced by capture of Mediterranean Outflow Water deep-sea current by the Portimão submarine canyon (Gulf of Cadiz, South Portugal). Marine Geology 242, 247-260. https://doi.org/10.1016/j.margeo.2007.03.013

Migeon, S., 2000. Dunes géantes et levées sédimentaires en domaine marin profond: approches morphologique, sismique et sédimentologique: Implications pour la reconnaissance des processus de transport et de dépôt des sédiments et pour la formation de corps sableux en domaine profond. Ph.D. Thesis, Université Bordeaux I. France. 288 pp.

Migeon, S., Savoye, B., Zanella, E., Mulder, T., Faugères, J.C., Weber, O., 2001. Detailed seismicreflection and sedimentary study of turbidite sediment waves on the Var Sedimentary Ridge (SE France): significance for sediment transport and deposition and for the mechanisms of sediment-wave construction. Marine and Petroleum Geology 18, 179-208. https://doi.org/10.1007/s11001-011-9123-3

Milliman, J. D., Syvitski, J. P., 1992. Geomorphic/tectonic control of sediment discharge to the ocean: the importance of small mountainous rivers. The Journal of Geology 100, 525-544. https://doi.org/10.1086/629606

Miramontes, E., 2016. Submarine landslides in the Northern Tyrrhenian Sea and relationship with the turbiditic and contouritic deposits: morphology, stratigraphy, geotechnics and modelling. Ph.D. Thesis, Université de Bretagne Occidentale, France. 215 pp.

Miramontes, E., Cattaneo, A., Jouet, G., Thereau, E., Thomas, Y., Rovere, M., Cauquil, E., Trincardi, F., 2016. The Pianosa Contourite Depositional System (Northern Tyrrhenian Sea): Drift morphology 
and Plio-Quaternary stratigraphic evolution. Marine Geology 378, 20-42. https://doi.org/10.1016/j.margeo.2015.11.004

Miramontes, E., Penven, P., Fierens, R., Droz, L., Toucanne, S., Jorry, S.J., Jouet, G., Pastor, L., Silva Jacinto, R., Gaillot, a., Giraudeau, J., Raisson, F., 2019. The influence of bottom currents on the Zambezi valley morphology (Mozambique Channel, SW Indian Ocean): in situ current observations and hydrodynamic modelling. Marine Geology. https://doi.org/10.1016/j.margeo.2019.01.002

Mitchell, N. C., 2014. Bedrock erosion by sedimentary flows in submarine canyons. Geosphere 10, 892-904. https://doi.org/10.1130/GES01008.1

Muck, M. T., Underwood, M. B., 1990. Upslope flow of turbidity currents: A comparison among field observations, theory, and laboratory models. Geology 18, 54-57. https://doi.org/10.1130/00917613(1990)018<0054:UFOTCA>2.3.CO;2

Mueller, C. O., Jokat, W., Schreckenberger, B., 2016. The crustal structure of Beira High, central Mozambique-Combined investigation of wide-angle seismic and potential field data. Tectonophysics 683, 233-254. https://doi.org/10.1016/j.tecto.2016.06.028

Nakajima, T., Satoh, M., Okamura, Y., 1998. Channel-levee complexes, terminal deep-sea fan and sediment wave fields associated with the Toyama Deep-Sea Channel system in the Japan Sea. Marine Geology 147, 25-41. https://doi.org/10.1016/S0025-3227(97)00137-0

Nelson, C. H., 1983. The Astoria Fan: an elongate type fan. Geo-marine Letters 3, 65-70. https://doi.org/10.1007/BF02462449

Normark, W. R., Hess, G. R., Stow, D., Bowen, A., 1980. Sediment waves on the Monterey Fan levee: a preliminary physical interpretation. Marine Geology 37, 1-18. https://doi.org/10.1016/0025$3227(80) 90009-2$ 
Normark, W. R., Piper, D. J., Posamentier, H., Pirmez, C., Migeon, S., 2002. Variability in form and growth of sediment waves on turbidite channel levees. Marine Geology 192, 23-58. https://doi.org/10.1016/\$0025-3227(02)00548-0

Normark, W. R., Posamentier, H., Mutti, E., 1993. Turbidite systems: state of the art and future directions. Reviews of Geophysics 31, 91-116. https://doi.org/10.1029/93RG02832

Olu, K, 2014. PAMELA-MOZ01 cruise, RV L'Atalante, http://dx.doi.org/10.17600/14001000

Pettingill, H. S. Weimer, P., 2002. Worlwide deepwater exploration and production: Past, present, and future. The Leading Edge 21,371-376. https://doi.org/10.1190/1.1471600

Picot, M., Droz, L., Marsset, T., Dennielou, B., Bez, M., 2016. Controls on turbidite sedimentation: insights from a quantitative approach of submarine channel and lobe architecture (Late Quaternary Congo Fan). Marine and Petroleum Geology 72, 423-446. https://doi.org/10.1016/j.marpetgeo.2016.02.004

Piper, D. J., Normark, W. R., 2001. Sandy fans--from Amazon to Hueneme and beyond. AAPG bulletin 85, 1407-1438. https://doi.org/http://dx.doi.org/10.1306/8626CACD-173B-11D7$8645000102 C 1865 D$

Piper, D. J., Savoye, B., 1993. Processes of late Quaternary turbidity current flow and deposition on the Var deep-sea fan, north-west Mediterranean Sea. Sedimentology 40, 557-582. https://doi.org/10.1111/j.1365-3091.1993.tb01350.x

Piqué, A., 1999. L'évolution géologique de Madagascar et la dislocation du Gondwana: une introduction. Journal of African Earth Sciences 28, 919-930. https://doi.org/10.1016/S0899$5362(99) 00069-X$

Pirmez, C., Imran, J., 2003. Reconstruction of turbidity currents in Amazon Channel. Marine and petroleum geology 20, 823-849. https://doi.org/10.1016/j.marpetgeo.2003.03.005 
Ponte, J. P., 2018. La marge africaine du canal du Mozambique (le système turbiditique du Zambèze) : une approche "Source to Sink » au Méso - Cénozoïque. Ph.D. Thesis, Université de Rennes 1. France. 351 pp.

Prather, B. E., Booth, J. R., Steffens, G. S., Craig, P. A., 1998. Classification, lithologic calibration, and stratigraphic succession of seismic facies of intraslope basins, deep-water Gulf of Mexico. AAPG bulletin $82,701-728$.

Quartly, G. D., Srokosz, M. A., 2004. Eddies in the southern Mozambique Channel. Deep Sea Research Part II: Topical Studies in Oceanography 51, 69-83. https://doi.org/10.1016/j.dsr2.2003.03.001

Raillard, S., 1990. Les marges de l'Afrique de l'Est et les zones de fractures associées: chaîne Davie et ride du Mozambique. Ph.D. Thesis, Université de Paris 6. France. 272 pp.

Raisson, F., Cazzola, C., Ferry, J.N., 2016. Deep oceanic currents and sea floor interactions offshore SE Africa. In: the EGU General Assembly Conference Abstracts 18, Vienna (Austria), 18459 pp.

Robin, C. and Droz, L., 2014. PAMELA-MOZ02 cruise, RV L'Atalante, http://dx.doi.org/10.17600/14001100

Romans, B. W., Castelltort, S., Covault, J.A., Fildani, A., Walsh, J., 2016. Environmental signal propagation in sedimentary systems across timescales. Earth-Science Reviews 153, 7-29. https://doi.org/10.1016/j.earscirev.2015.07.012

Schlich, R., Saint-Maur-des-Fossés, F., 1974. 34. Regional aspects of deep sea drilling in the Western Indian Ocean, leg 25, Deep Sea Drilling Project. doi:10.2973/dsdp.proc.25.109.1974

Schulz, H., Lückge, A., Emeis, K.-C., Mackensen, A., 2011. Variability of Holocene to Late Pleistocene Zambezi riverine sedimentation at the upper continental slope off Mozambique, $15^{\circ}-21^{\circ} \mathrm{S}$. Marine Geology 286, 21-34. https://doi.org/10.1016/j.margeo.2011.05.003 
Simpson, E. S. W. , Schlich, R., Gieskes,J., Girdley, W. A., Leclaire, L., Marshall, V. B., Moore, C., Muller, C., Sigal, J., Valuer, T. L. , White S. M. and Zobel, B., 1974. Sites 243 and 244. In: Simpson, E. and Schlich, R. (Ed.): Initial Reports of the Deep Sea Drilling Project, Volume 25, 743-760. U.S. Government Printing Office, Washington, D.C. doi:10.2973/dsdp.proc.25.106.1974

Skene, K. I., Piper, D. J., 2006. Late Cenozoic evolution of Laurentian Fan: development of a glaciallyfed submarine fan. Marine Geology 227, 67-92. https://doi.org/10.1016/j.margeo.2005.12.001

Stow, D. A., Bowen, A. J., 1980. A physical model for the transport and sorting of fine-grained sediment by turbidity currents. Sedimentology $27,31-46$. https://doi.org/10.1016/00370738(80)90052-4

Stow, D. A., Mayall, M., 2000. Deep-water sedimentary systems: New models for the 21st century. Marine and Petroleum Geology 17, 125-135. https://doi.org/10.1016/S0264-8172(99)00064-1

Thompson, J. O., 2017. The opening of the Indian Ocean: what is the impact on the East African, Madagascar and Antarctic margins, and what are the origins of the aseismic ridges? Ph.D. Thesis, Université de Rennes 1. France. 189 pp.

Uenzelmann-Neben, G., Watkeys, M. K., Kretzinger, W., Frank, M., Heuer, L., 2011. Palaeoceanographic interpretaion of a seismic profile from the Southern Mozambique Ridge, Southwestern Indian Ocean. South African Journal of Geology 114, 449-458. https://doi.org/10.2113/gssajg.114.3-4.449

Van Aken, H. M., Ridderinkhof, H., de Ruijter, W. P., 2004. North Atlantic deep water in the southwestern Indian Ocean. Deep Sea Research Part I: Oceanographic Research Papers 51, 755-776. https://doi.org/10.1016/j.dsr.2004.01.008

Walford, H., White, N., Sydow, J., 2005. Solid sediment load history of the Zambezi Delta. Earth and Planetary Science Letters 238, 49-63. https://doi.org/10.1016/j.epsl.2005.07.014 
Weimer, P., Link, M.H., 1991. Global petroleum occurrences in submarine fans and turbidite systems, in: Seismic Facies and Sedimentary Processes of Submarine Fans and Turbidite Systems. Springer, 9-67. https://doi.org/10.1007/978-1-4684-8276-8_2

Wiles, E., Green, A. N., Watkeys, M. K., Jokat, W., Krocker, R., 2013. The evolution of the Tugela canyon and submarine fan: a complex interaction between margin erosion and bottom current sweeping, southwest Indian Ocean, South Africa. Marine and Petroleum Geology 44, 60-70. https://doi.org/https://doi.org/10.1016/j.marpetgeo.2013.03.012

Wiles, E., Green, A. N., Watkeys, M. K., Jokat, W., Krocker, R., 2014. A new pathway for Deep water exchange between the Natal Valley and Mozambique Basin? Geo-Marine Letters 34, 525-540. https://doi.org/10.1007/s00367-014-0383-1

Wiles E, Green AN, Watkeys MK, Jokat W, 2017a. Zambezi continental margin: compartmentalized sediment transfer routes to the abyssal Mozambique Channel. Marine Geophysical Research 38, 227-240. doi:10.1007/s11001-016-9301-4

Wiles, E., Green, A. N., Watkeys, M., Jokat, W., 2017b. The Zambezi Channel: A new perspective on submarine channel evolution at low latitudes. Geomorphology 286, 121-132. https://doi.org/10.1016/j.geomorph.2017.02.014

Winker, C. D., 1996. High-resolution seismic stratigraphy of a late Pleistocene submarine fan ponded by salt-withdrawal mini-basins on the Gulf of Mexico continental slope. In Offshore Technology Conference. Offshore Technology Conference, 6-9 May, Houston, Texas. 619-628. https://doi.org/10.4043/8024-MS

Winkler, W., 1993. Control factors on turbidite sedimentation in a deep-sea trench setting.-The example of the Schlieren Flysch (Upper Maastrichtian-Lower Eocene, Central Switserland). Geodinamica Acta (Paris) 6, 81-102. https://doi.org/10.1080/09853111.1993.11105240 
Wynn, R. B., Weaver, P. P., Ercilla, G., Stow, D. A., Masson, D. G., 2000. Sedimentary processes in the Selvage sediment-wave field, NE Atlantic: new insights into the formation of sediment waves by turbidity currents. Sedimentology 47, 1181-1197. https://doi.org/10.1046/j.1365$3091.2000 .00348 . x$

Wynn, R. B., Cronin, B. T., Peakall, J., 2007. Sinuous deep-water channels: Genesis, geometry and architecture. Marine and Petroleum Geology 24 (6-9), 341-387. https://doi.org/10.1016/j.marpetgeo.2007.06.001

Zhang, T., Lin, J., Gao, J., 2011. Interactions between hotspots and the Southwest Indian Ridge during the last $90 \mathrm{Ma}$ : implications on the formation of oceanic plateaus and intra-plate seamounts. Science China Earth Sciences 54, 1177-1188. https://doi.org/10.1007/s11430-011-4219-9 


\section{Figure captions}

Figure 1: (A) Catchments of main rivers contributing to the sedimentation in the Mozambique Channel (from http://www.fao.org/geonetwork). (B) Physiographic map of the present-day Mozambique Channel showing main sedimentary and structural features. Compiled from published literature: (1) Schulz et al., 2011; (2) Kolla et al., 1980b; (3) Beiersdorf et al., 1980; (4) Gebco, 2014; (5) Wiles et al., 2017a; (6) Breitzke et al., 2017; (7) Kolla et al., 1980a; (8) Raillard, 1990; (9) Thompson, 2017; (10) Raisson et al., 2016; (11) Mahanjane, 2012; (12) Mahanjane, 2014; (13) Schematized from Courgeon et al., 2017 and Deville et al., 2018; (14) Ponte, 2018, partly based on Baby, 2017;. Cores from IODP leg 361 (green stars) (Hall et al., 2016), from DSDP leg 25 (white stars) (Simpson et al., 1974) and from Kolla et al. (1980a) (yellow hexagons) are indicated.

Figure 2: Overview of the surface (red) and deep water (blue) circulation present in the Mozambique Channel (after De Ruijter et al., 2002; Schulz et al., 2011; Uenzelmann-Neben et al., 2011; Halo et al., 2014). Bathymetric map based on GEBCO (2014) data. Contour lines are indicated in meters, spaced at $1000 \mathrm{~m}$ intervals. AABW = Antarctic Bottom Water, AAIW $=$ Antarctic Intermediate Water, EACC $=$ East African Coastal Current, $\mathrm{MC}=$ Mozambique Current, MUC $=$ Mozambique Undercurrent, NADW $=$ North Atlantic Deep Water, SEMC $=$ Southern branch of the East Madagascar Current.

Figure 3: Slope map (GEBCO, 2014) of the Mozambique Channel with location of existing data. Colored lines: data used in this study (multibeam bathymetry and sub-bottom seismic tracks). Blue: PTOLEMEE (Jorry, 2014). Orange: PAMELA-MOZ1 (Olu, 2014). Green: PAMELA-MOZ2 (Robin and Droz, 2014). Red: PAMELA-MOZ4 (Jouet and Deville, 2015). Black lines: Previous data used by Breitzke et al. (2017) and Wiles et al. (2017a, b). Pink polygon: approximation of the extent of data used by Kolla et al. (1980a, b).

Figure 4: Measured parameters. A: Nomenclature used in this paper. i: Detail of bathymetric map; ii: Typical depth cross-section of the Zambezi Valley. B: Measured parameters on depth cross-sections. Wv: Valley width, Rv: Valley relief, Wt: Thalweg width, Rt: Thalweg relief. C: Calculation method of cross-sectional areas of the valley and thalweg. D: Location of cross-sections where width and relief of the thalweg (pink and black lines) and the valley (black lines) have been measured. Reference point for distances in the graphs of figure 7, 8 and 9 is taken at the shelf break in the extension of the Zambezi Valley. 
Figure 5: Schematic representation of sediment waves and measured parameters. WL: wave length (in $\mathrm{km}$ ), WH: wave height (in $\mathrm{m}$ ) and LC: crest length (in $\mathrm{km}$ ).

Figure 6: Main morphological features of the Mozambique Channel. A: Bathymetric map based on GEBCO (2014) data. The outline of Beira High is taken from Mahanjane (2012). B: Transverse depth profiles (d to $h$ in A) of the Mozambique Channel. C: Along-slope profiles (a to c in A). Position of the Miocene doming on alongslope profiles a and $\mathrm{c}$ is deduced from the mapping of the doming by Ponte (2018) (see Fig. 1B).

Figure 7: Morphological characteristics of the Zambezi Valley. A: PAMELA bathymetric map (100 m resolution) over the Gebco 2014 grid ( $1 \mathrm{~km}$ resolution). B: Transverse depth profiles (transects 1 to 15 indicated as red lines in A). C: Along valley depth profile (black line with dots in A). The 0 reference point for the along-valley distances is taken at the shelf break in the extension of the Zambezi Valley (as illustrated in figure 4).

Figure 8: Vertically exaggerated depth profile of the Zambezi Valley floor showing the ungraded profile with several slope increases and decreases. Profile based on PAMELA bathymetric data (100 m resolution). The 0 reference point for the along-valley distances is taken at the shelf break in the trend of the Zambezi Valley (see figure 4). $S B=$ southern branch confluence, $S P=$ Serpa Pinto paleo-confluence, $T=$ Tsiribihina confluence, $K P=$ knickpoint.

Figure 9: Downstream evolution of morphological parameters of the valley (black curves) and thalweg (green curves) of the Zambezi Valley (see Fig. 4 for the morphological definitions of the valley and the thalweg, for the location of width and relief measurements and for the approximation of the cross-sectional areas). A: simplified depth profile along the valley floor (extracted from depth profile on Fig. 7C, cut at $1300 \mathrm{~km}$ ). KP: knickpoint. B: Width evolution. C: Relief evolution. D: Aspect ratio (W/R). E: Cross-sectional areas evolution. Owing to the approximations of cross-sectional areas calculations, the thalweg and valley curves have been smoothed. Notice also the different vertical scales for the thalweg and valley graphs. Numbers in B refer to transverse depth profiles (Fig. 7B) where the valley width and relief have been measured.

Figure 10: Morphological characteristics of the Zambezi and Tsiribihina Valley confluence zone. A: Along valley depth profiles of the Zambezi and Tsiribihina Valleys (position of transverse profiles shown in B indicated with red lines). $\mathrm{KP}=$ knickpoint. The confluence between the Zambezi and Tsiribihina Valley is chosen as $0 \mathrm{~km}$ point, 
which lies $780 \mathrm{~km}$ from the 0 reference point at the shelf break (see Fig. 4). B: Bathymetric map based on PAMELA bathymetric data (100 m resolution). Dashed lines indicate Zambezi Valley limits. C: Transverse depth profiles (transects 1 to 11 indicated as red lines in B). Z: Zambezi Valley, T: Tsiribihina Valley.

Figure 11: Surface sediment distribution in the Mozambique Channel (grey lines: ship tracks). A: Echo facies distribution (description of facies in Table 2 and text). See examples of echo facies in Figs 12 and 13. Distally in the study area, incised distributary channels are mapped (black lines). B: Interpretation of (A) in terms of depositional/erosional sedimentary systems. Red squares: location of the bathymetric zooms of Figs. 14-18 and 20-23.

Figure 12: Chirp profiles showing typical transparent echo facies and their transition with other facies, on the Mozambique slope and distal area (see $G$ for location). A: transition between transparent ( $T$ ) and stratified (S3) echo facies. B: transition between stratified (S1) and transparent (T) echo facies. C: transition between transparent (T) and stratified (S1 and S3) echo facies on the Mozambique slope. D: transition between transparent (T) and stratified (S1) echo facies West of lles Eparses. E: transition between transparent (T) and stratified (S1 and S3) echo facies SW of lles Eparses. F: transparent (T) echo facies in the distal depositional area. Same horizontal and vertical scales in A to F. G: Extraction of Fig. 11A with location of profiles A to F.

Figure 13: Chirp profiles illustrating transitions between different echo facies (see E for location). A: stratified (S1) facies characterizing the Madagascar Margin. B: transition between hyperbolic ( $\mathrm{H})$, stratified (S2) and transparent (T) sediment echo facies near the Mozambique Ridge. C: transition of transparent $(T)$ towards hyperbolic (H) facies at the base of the Madagascar Ridge. D: stratified (S4 and S3), transparent (T) and opaque (O) facies at the downstream portion of the Zambezi Fan. E: Extraction of Fig. 11A with location of profiles A to D.

Figure 14: Bathymetric map at the confluence of 2 tributaries (Northern and Southern branches) in the most upstream surveyed portion of the Zambezi Valley. Left: original data with location of ship tracks (black lines). Right: interpreted map and characteristic depth profiles. Position is indicated on Fig. 11B.

Figure 15: Bathymetric map on a bent form characterizing the northern portion of the Zambezi Valley. Left: bathymetric data upon a slope raster with location of ship tracks (black lines). Right: interpreted map and 
depth profiles (red lines). The darkest grey color indicates more recent time incision. Position is indicated on Fig. 11B.

Figure 16: Morphology of the Zambezi Valley where it approaches the Davie Ridge. A: bathymetric data upon a slope raster with location of the ship tracks (black lines). B: interpreted map with depth profiles (red lines 1 to 4). The darkest grey color indicates more recent incision. Thick black lines are faults observed on bathymetric data. Dashed lines indicate potential extension of faults. Position is indicated on Fig. 11B. Notice that the along valley depth profile 1 is not strictly at the same position as the depth profile in figures 7 and 8 (i.e. the $80 \mathrm{~m}$ knickpoint in figures 7-8 do not correspond to the $30 \mathrm{~m}$ scar observed here). C: Seismic profile PTO-SR-mig093 (Jorry, 2014) along the collapsed valley flank (position in B).

Figure 17: Bathymetric map at the Zambezi and Tsiribihina Valley confluence zone. A: bathymetric data upon a slope raster. B: interpreted map with the position of the depth profile (red line) shown in (1). The darkest grey color indicates more recent time incision. $\mathrm{KP}=$ knickpoints, see Fig. 10. Position of the map is indicated on Fig. $11 \mathrm{~B}$.

Figure 18: Distal depositional area of the Zambezi Fan. A: Extract from Fig. 11B that shows proposed connections of distributary valleys (however these correlations remain uncertain) and depth profiles shown in D (black lines). B: Bathymetric map and interpretation based on PAMELA bathymetric data (resolution $100 \mathrm{~m}$ ) illustrating a channel-levee system at the right hand side of the Zambezi incisions (blue square in A). C: Seismic profile MOZ4-SR-234c oblique to the channel-levee system (position in B) (Jouet and Deville, 2015). D: Depth profiles 2 and 3 (location in A) and chirp profiles a and b (with different vertical scales).

Figure 19: Bathymetric map demonstrating recent erosion recognized in the distal portion of the turbidite system. Left: bathymetric data upon slope raster with location of ship tracks (black lines). Right: interpreted map and depth profiles (red lines). A1 to C3 (from the oldest to the youngest) are successive elongated erosional channel-like features. Position is indicated on Fig. 11B.

Figure 20: Bathymetric map of fossil sediment waves northeast of lles Eparses (location in Fig. 11B). A: Depth profile taken along the A line on the bathymetric map. B: Chirp profile along line B on the bathymetric map. C 
and D: interpretation of chirp profile B with different vertical exaggeration. Green: blanking turbidite deposition; pink: contouritic sediment waves; white: onlaping unit of unknown nature.

Figure 21: Bathymetric map and its interpretation of sub-circular bedforms observed east of Bassas da India (location in Fig. 11B). A and B: depth profile; 1 and 2: chirp profiles.

Figure 22: Bathymetric map of polygonal sediment waves observed southeast of Europa (location in Fig. 11B). A and B: depth profiles; 1 and 2: chirp profiles.

Figure 23: Bathymetric map and its interpretation of anastomosed sediment waves observed $230 \mathrm{~km}$ south of the lles Eparses (location in Fig. 11B). A and B: depth profiles; 1 and 2: chirp profiles.

Figure 24: Synthetic sedimentary organization of the Mozambique Channel and Zambezi turbidite system, from bathymetric and sub-bottom reflection studies and from literature (adapted to the Zambezi turbidite system from a sketch by Gamberi and Rovere, 2011). The Zambezi River inputs are transferred to the turbidite system in two ways, either by (A) a channelized fan (the so-called Zambezi Fan) that transfers the sediments towards the South about $1200 \mathrm{~km}$ downstream and by (B) the ponded fan mainly limited downstream by a coutouritic ridge that generally limit the turbidites deposition to the so-called Intermediate Basin. Channels that flow towards the Southwest (see Fig. 1, Wiles et al., 2017a) show that the Intermediate Basin is not entirely closed (semi-confined fan).

Figure 25: Comparison of the Zambezi Valley dimensions (black lines) with other well-known deep-sea turbidite channels (colored solid lines). Curves for other systems are redrawn form Hesse et al. (1987), Babonneau et al. (2002), Pirmez and Imran (2003), Bourget et al. (2008) and Fournier (2016). For the Zambezi system, solid line represents the $\mathrm{V}$-shaped valley, and dashed line represents the U-shaped thalweg. A: Channel relief (from valley bottom to levee crest in the Congo, Amazon, Tanzanian Valley and NAMOC). B: Channel width (from levee crests in the Congo, Amazon, Tanzanian Valley and NAMOC). Position of the bathymetric cross-sections and reference point for distance $(0 \mathrm{~km})$ for the Zambezi Valley is shown in figure 4 . Position of the fault zone refers exclusively to the Zambezi Fan (Fig. 16). C: Channel aspect ratio (R/W) plotted as a function of average along-channel slope, based on Skene and Piper (2006), Bourget et al. (2008) and this study (Zambezi thalweg 
dimensions, see Figs. 7 and 9 for average R/W vs average slopes). Squared numbers refer to the fan types 1 to 4 of the classification of Piper and Normark (2001).

Figure 26: Maximum (A) and mean (B) speed of bottom circulation simulated from 1993 to 2014 with the Regional Ocean Modelling System (ROMS). Blue arrows in B: mean bottom current directions obtained from the model. Contours of the model bathymetry are shown every $500 \mathrm{~m}$ (Gebco 2014 data). Numbered rectangles indicate position of figures 20 to 23. Modified from Miramontes et al. (2019).

\section{Table captions}

Table 1: Data used in this study.

Table 2: Description and interpretation of echo classes observed in the study area. For each echo class an example is shown with its color code used for the map in Fig. 11A. For additional examples see Fig. 12 to 13. 